INTER NATIONAL MONETARY FUND

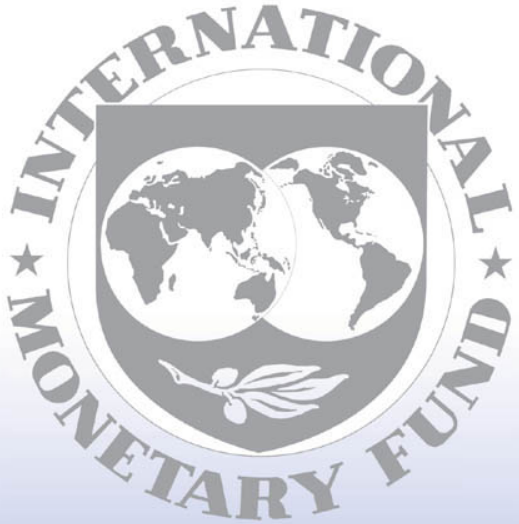

Staff

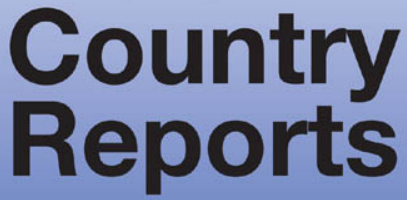




\section{Russian Federation: Selected Issues}

This Selected Issues paper for the Russian Federation was prepared by a staff team of the International Monetary Fund as background documentation for the periodic consultation with the member country. It is based on the information available at the time it was completed on July 18, 2007. The views expressed in this document are those of the staff team and do not necessarily reflect the views of the government of the Russian Federation or the Executive Board of the IMF.

The policy of publication of staff reports and other documents by the IMF allows for the deletion of market-sensitive information.

To assist the IMF in evaluating the publication policy, reader comments are invited and may be sent by e-mail to publicationpolicy@imf.org.

Copies of this report are available to the public from

International Monetary Fund $\bullet$ Publication Services

700 19th Street, N.W. • Washington, D.C. 20431

Telephone: (202) 6237430 • Telefax: (202) 6237201

E-mail: publications@imf.org • Internet: http://www.imf.org

Price: $\$ 18.00$ a copy

\section{International Monetary Fund Washington, D.C.}


This page intentionally left blank 


\section{INTERNATIONAL MONETARY FUND}

\section{RUSSIAN FEDERATION}

\section{Selected Issues}

Prepared by Ritu Basu, Gunes Kamber, Hajime Takizawa, Harm Zebregs (all EUR), and David Hauner (FAD)

Approved by the European Department

July 18,2007

Contents

I. Understanding Russia's Inflation in the Post-1998 Crisis Period

A. Introduction

B. Inflation Persistence

C. Inflation Evolution in Response to Structural Shocks-SVAR

D. Concluding Remarks.

\section{Text Tables}

1. CEE and Selected Emerging Countries: Consumer Price Inflation, 2006 ......................

2. Reduced-Form Estimation of NKPC ……………..................................................

3. Forecast Error Variance Decomposition of Core Inflation.........................................11

Figure

1. Impulse Responses to a Positive Interest Rate Shock..................................................10

Text Figure

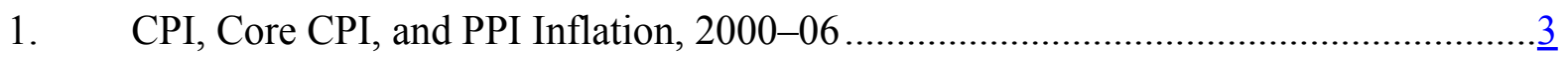

2. Impulse Responses to a Positive Interest Rate Shock.................................................10

3. Impulse Responses of Inflation to Shocks to Other Variables ....................................10

\section{Text Boxes}

1. Univariate Approach to Measuring Inflation Presistence..............................................

2. Structural Model Underlying the Hybrid NKPC ……..............................................

3. Identification of Structural Shocks .......................................................................

Appendix

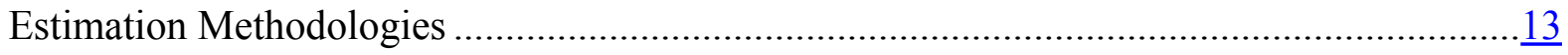

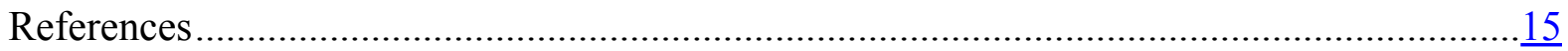


II. Benchmarking the Efficiency of Public Expenditure in the Russian Federation................ $\underline{16}$

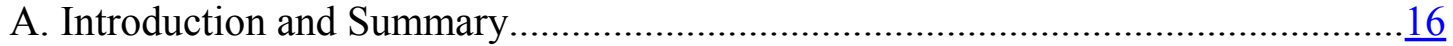

B. Methodological Issues................................................................................ $\frac{17}{17}$

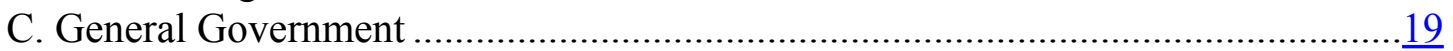

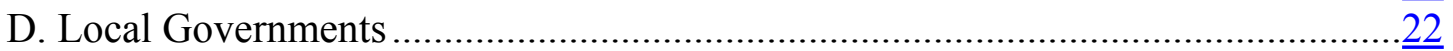

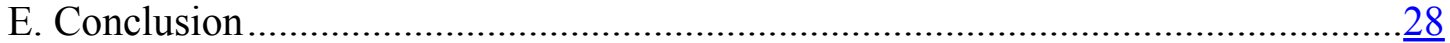

Tables

1. General Government-Multiple-Outcome Health Efficiency Model .......................29

2. General Government-Multiple-Outcome Education Efficiency Model.................... $\underline{30}$

3. General Government — Social Protection Efficiency Model ....................................31

4. Local Governments_-Data Description..........................................................

5. Local Governments - Summary of Performance and Efficiency Scores ................... $\underline{33}$

Figures

1. Income Level and General Government Spending ...........................................34

2. Structure of General Government Spending - Functional Classification.....................35

3. Structure of General Government Spending - Economic Classification .................... 35

4. General Government - Efficiency of Private and Public Health Spending (I)............ $\underline{36}$

5. General Government - Efficiency of Private and Public Health Spending (II) ........... 37

6. General Government - Efficiency of Public Education Spending .............................38

7. General Government_Efficiency of Social Protection Spending ...........................39

8. Local Governments - Income Level and Government Spending ............................. 40

9. Local Governments_-PSP, PSE, and DEA Scores vs. Spending in Percent of GRP. $\underline{41}$

Text Box

1. Explanatory Variables - Motivation and Results ...............................................25

Appendices

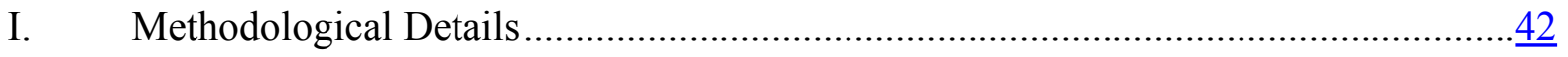

II. Background Tables for Local Governments .................................................. 46

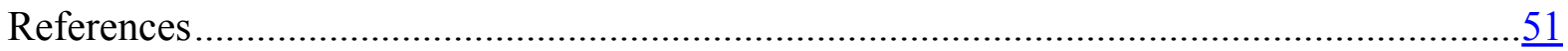




\section{Understanding Russia's Inflation in the Post-1998 Crisis Period ${ }^{1}$}

\section{A. Introduction}

\section{Inflation in Russia has been} characterized by a considerable degree of persistence. After an initial rapid decline from about 30 percent in 2000 to close to 10 percent in 2003, annual headline consumer price inflation became entrenched at $10-14$ percent until early $2005 .^{2}$ Since then, inflation has declined to about 8 percent, but it remains higher than in many other emerging market economies (Table 1). ${ }^{3}$ Indeed, inflation in most of these countries was in the low single digits in 2006, while inflation in Russia was still close
Table 1. CEE and Selected Emerging Countries: Consumer Price Inflation, $20061 /$

(Annual percent change)

\begin{tabular}{llll}
\hline Russia & $\mathbf{9 . 7}$ & Czech Republic & 2.5 \\
& & Estonia & 4.4 \\
Brazil & 4.2 & Hungary & 3.9 \\
Chile & 3.4 & Latvia & 6.6 \\
China & 1.5 & Lithuania & 3.8 \\
India & 5.8 & Poland & 1.1 \\
Kazakhstan & 8.6 & Slovak Republic & 4.5 \\
South Africa & 4.6 & Slovenia & 2.5 \\
& & Turkey & 9.5 \\
\hline
\end{tabular}

Source: IMF's $I F S$

1/ CEE stands for Central and Eastern Europe.

\section{Different measures of inflation} point to a similar degree of entrenchment (Figure 1). Core consumer price inflation, which excludes the effects of administered prices and volatile prices of fruits and vegetables, followed a disinflation process similar to that of headline consumer price inflation, although it had already become entrenched at $10-13$ percent in 2002 and remained in that range until mid-2005. Core inflation has generally been lower than headline

Figure 1. Russia: CPI, Core CPI, and PPI Inflation, 2000-2006 (Year-on-year change; in percent)

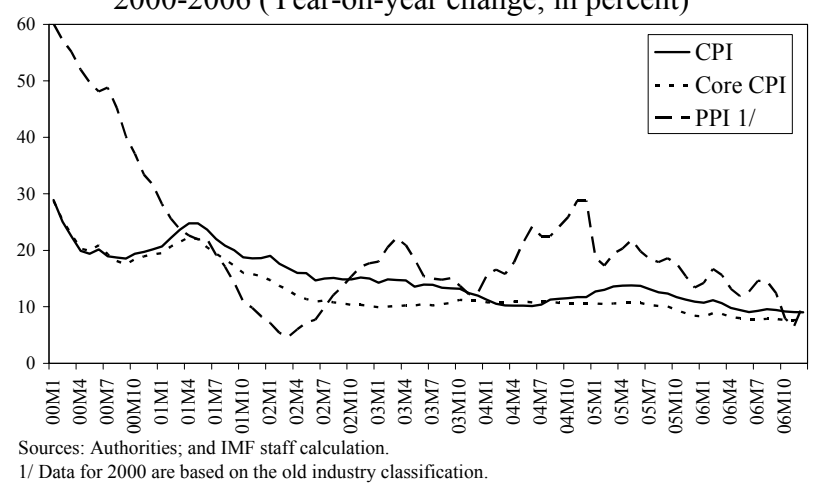
inflation because it excludes administered prices, which have been a major contributor to headline inflation. Producer price inflation has followed a more volatile path, but it is also

\footnotetext{
${ }^{1}$ Prepared by Ritu Basu, Gunes Kamber, Hajime Takizawa, and Harm Zebregs.

${ }^{2}$ CPI inflation was 28.9 percent year on year in January 2000 and declined to 12 percent year on year in December 2003.

${ }^{3}$ Inflation decelerated further in the first quarter of 2007. Headline consumer price and core consumer price inflation (year on year) declined to 7.4 percent and 6.6 percent, respectively, in March 2007. Producer price inflation (year on year) decelerated to 3.1 percent in March. However, in May 2007, headline consumer price inflation rose to 7.8 percent, core consumer price inflation to 6.8 percent, and producer price inflation 10.7 percent.
} 
characterized by an initial decline, albeit a more pronounced one, followed by a period of entrenchment at rates between 10-30 percent year on year.

3. This chapter investigates the key factors driving inflation in Russia in the period after the 1998 financial crisis. Understanding Russia's inflation process is important in the context of designing monetary policy. In particular, as Russia intends to move to formal inflation targeting over the medium term, it is key to gain a good grasp of the determinants of inflation, as well as of the role of monetary policy in anchoring inflation expectations. This chapter, therefore, explores the role of expectations in Russia's inflation persistence and the response of inflation to various exogenous shocks. This is done by estimating a new Keynesian Phillips curve (NKPC) and a structural vector auto regression (SVAR) model.

4. The results indicate that inflation in Russia tends to be more persistent than inflation in other Central and Eastern Europe (CEE) countries and that the exchange rate is one of main channels that affect inflation. The estimated half-life - the time needed to halve the magnitude of the original shock - for Russia is longer than estimates for other CEE countries. The estimation of a NKPC, which links inflation to both forward-looking inflation expectations and backward-looking behavior in price setting (approximated by past realizations of inflation), as well as the real marginal cost of production, suggests that backward-looking behavior is relatively important in determining inflation in Russia. ${ }^{4}$ In comparison, inflation in industrial countries is mainly driven by forward-looking expectations, which can be anchored by monetary policy. The results of the SVAR show that exchange rate shocks have a larger impact on core inflation than interest rate shocks and that in the post-1998 crisis period core inflation has to a large extent been driven by exchange rate shocks and surprise inflation shocks.

5. The remainder of this chapter is organized as follows. Section B describes the inflation persistence in Russia and estimates a NKPC. Section C reports the estimation results of an SVAR model. Section D discusses policy implications and concludes.

\section{B. Inflation Persistence}

6. Inflation in Russia appears to be more persistent than that in other CEE countries. The degree of inflation persistence can be measured by an estimated half-life of a unit shock to a univariate inflation process, the time needed to halve the magnitude of the original shock to the process (Box 1). The estimated half-life for Russia (at three-and-a-half months), based on monthly changes in the seasonally adjusted core consumer price index (CPI), is found to be higher than that in other CEE countries. In contrast, similar half-life estimates range from less

\footnotetext{
${ }^{4}$ Banerji and others (2003) found that, while nominal wage indexation to inflation in Russia was significantly less prevalent than in other European transition countries, such as Hungary, Poland, Estonia, Latvia, and Lithuania, the authorities' commitment to the disinflation process was weaker in Russia.
} 
than a month for the Czech Republic, about a month for Hungary, and one-and-a-half months to two-and-a-half months for Poland over the 1994-2005 period (Abiad, Leigh, and Fabrizio, 2005). Celasun, Gelos, and Prati (2003) estimates a half-life of one month for Turkey over the 1999-2002 period.

\section{Box 1. Univariate Approach to Measuring Inflation Persistence}

A univariate specification assumes that current-period inflation depends on its one-period lag and current-period innovation:

$$
\pi_{t}=\beta \pi_{t-1}+\varepsilon_{t},
$$

where $\pi_{t}$ and $\varepsilon_{t}$ are period $t$ inflation and innovation, respectively. The higher the estimated parameter $B$, the stronger is persistence. The estimated parameter value can be translated into a more intuitive measure, an estimate of the half-life of a unit shock to inflation, defined as

$$
\text { half life }=\frac{\ln (1 / 2)}{\ln (\beta)}
$$

This measure indicates the time needed to halve the magnitude of the original shock.

7. Inflation persistence has important policy implications. With higher inflation persistence, it will take a stronger tightening of monetary policy to achieve a given inflation objective; this implies that the cost, in terms of forgone output, of a disinflation policy will be higher.

\section{The NKPC can be employed to obtain a better understanding of the nature of}

inflation persistence. This chapter uses a hybrid NKPC that links inflation to lagged inflation, expected future inflation, and the real marginal cost of production. ${ }^{5}$ In this approach, inflation, measured as monthly changes in the producer price index (PPI), is modeled as

$$
\pi_{t}=\gamma^{f} E_{t} \pi_{t+1}+\gamma^{b} \pi_{t-1}+\lambda \cdot M C_{t}+\varepsilon_{t}
$$

where $\pi_{t}$ is inflation in period $t, M C_{t}$ is the real marginal cost of production in period $t$, and $\varepsilon_{t}$ is the innovation in period $t$. The real marginal cost captures the conventional Phillips curve trade-off between inflation and output growth. ${ }^{6}$ Firms are assumed to set prices based on movements in marginal costs associated with variations in excess demand. By estimating the above equation it is possible to assess the relative importance of expected future inflation

\footnotetext{
${ }^{5}$ The hybrid NKPC is based on Gali and Gertler (1999).

${ }^{6}$ Under certain conditions, the marginal cost of production can be expressed in terms of the output gap.
} 
(forward-looking behavior) and lagged inflation (backward-looking behavior) in the determination of inflation in Russia.

\section{The estimation of the reduced-form hybrid NKPC model reveals that lagged} inflation has played an important role in inflation determination in Russia. Equation (1) is estimated using the generalized method of moments (GMM) with four lags of PPI, core CPI, and two lags of marginal cost as instruments. In addition to the unrestricted model, a model with the following restriction is also estimated:

$$
\gamma^{b}+\gamma^{f}=1
$$

This restriction is common in NKPC estimations as it implies no long-run trade-off between output and inflation. ${ }^{7}$ The estimated coefficient for lagged inflation is significant and ranges between 0.56 and 0.57 (Table 2). ${ }^{8,9}$ This contrasts with estimates for developed countries in which the forward-looking component dominates inflation dynamics.

Table 2. Reduced-Form Estimation of NKPC 1/ 2/3/

\begin{tabular}{lccc} 
& $\gamma^{\mathrm{b}}$ & $\gamma^{\mathrm{f}}$ & $\lambda$ \\
\hline Unrestricted & $0.57^{* *}$ & $0.38^{* *}$ & $0.03^{* *}$ \\
& $(0.019)$ & $(0021)$ & $(0.004)$ \\
& & & \\
Restricted: $\gamma^{\mathrm{b}}+\gamma^{\mathrm{f}}=1$ & & $0.44^{* *}$ & $0.032^{* *}$ \\
& & $(0.019)$ & $(0.004)$ \\
\hline
\end{tabular}

$1 /$ Real unit labor cost is used for marginal cost.

$2 / * *$ means significant at the 1 percent level.

3/ Figures in parentheses are standard errors.

\footnotetext{
${ }^{7}$ By replacing $M C$ with the output gap in (1), it is clear that the output gap is independent of inflation under the restriction.

${ }^{8}$ The estimated value is robust to various measures of the marginal cost of production. One such measure is the real effective exchange rate (REER), which would capture the openness of the Russian economy. Even after replacing unit labor costs with the REER as a regressor, the estimated coefficient remains close to 0.5 and significant at the 1 percent level.

${ }^{9}$ The NKPC can be also estimated for underlying structural parameters (see Box 2 for structural parameters). The values of the coefficients for the components of forward- and backward-looking behavior ( $\gamma^{f}$ and $\gamma^{b}$, respectively) that are implied by the estimated structural parameters are close to those derived from the estimation of a reducedform equation. The implied $\gamma^{b}$ under no restriction is 0.52 , while the implied $\gamma^{b}$ under the restriction $\gamma^{f}+\gamma^{b}=1$ is 0.55 .
} 


\section{Box 2. Structural Model Underlying the Hybrid NKPC}

The hybrid NKPC model is based on the price-setting behavior of monopolistically competitive firms facing nominal rigidities. The forward-looking component and real marginal cost of production in the aggregate inflation equation (1) follow from the following staggered price-setting behavior of individual firms facing nominal rigidities. Each firm chooses its nominal price to maximize profits subject to constraints on the frequency of future price adjustments. In any given period, only a randomly selected fraction, 1- $\theta$, of firms may change their nominal prices while the remaining fraction, $\theta$, of firms keep their prices unchanged. The average waiting time for a firm to get an adjustment opportunity is therefore $1 /(1-\theta)$. ${ }^{1}$ The backward-looking component in the inflation equation (1) emerges with the introduction of an additional assumption à la Gali and Gertler (1999) that a fraction, $\omega$, of firms having the opportunity to adjust their prices do not follow profit-maximizing behavior but rather a rule of thumb of simply indexing prices to lagged inflation. With the subjective discount factor denoted by $B$, parameters in the reduced-form inflation equation (1) can be defined as functions of the underlying structural parameters as follows:

$$
\begin{aligned}
& \lambda=\frac{(1-\theta)(1-\omega)(1-\theta \beta)}{\theta+\omega(1-\theta(1-\beta))}, \\
& \gamma^{f}=\frac{\theta \beta}{\theta+\omega(1-\theta(1-\beta))}, \text { and } \\
& \gamma^{b}=\frac{\omega}{\theta+\omega(1-\theta(1-\beta))} .
\end{aligned}
$$

These functions indicate that persistence of inflation emerges endogenously from individual firms' backward-looking price-setting behavior.

${ }^{1}$ This formulation follows Calvo (1983).

\section{The large role played by backward-looking behavior in the determination of} inflation suggests that disinflation is costly in Russia. As noted above, the sizable inflation inertia characterized by the backward-looking component of the NKPC implies a more costly disinflation process. This may depend on the limited credibility of monetary policy; indeed, the Central Bank of Russia (CBR) has primarily subordinated its inflation targets to the goal of resisting nominal exchange rate appreciation. In doing so, it has accommodated inflationary shocks that have likely reinforced the inflation inertia.

\section{Inflation Evolution in Response to Structural Shocks-SVAR}

\section{This section investigates the response of inflation to various unexpected exogenous}

shocks. This analysis, based on the estimation of an SVAR, is important in gaining a better understanding of the transmission process in Russia. While SVAR models have their shortcomings, they have been used extensively to investigate monetary transmission mechanisms in other countries. Key to SVAR models is the identification of structural shocks based on restrictions deriving from economic theory. The identifying restrictions for the analysis in this section are discussed in Box 3. Furthermore, like other VAR models, SVAR models can be used to perform a variance decomposition, which shows how each variable in the 


\section{Box 3. Identification of Structural Shocks}

A seven-variable open economy SVAR model is estimated for the period 2000-06 using monthly data. Core consumer price inflation is used as a measure of inflation. Other variables include broad money (including foreign currency deposits), industrial production, the U.S. Federal Fund rate (FF rate), the oil price, the nominal effective exchange rate (NEER), and nominal deposit rate. Including both broad money and the deposit rate will allow money demand and money supply shocks to be identified separately.

The SVAR is estimated with all variables defined as year-on-year changes. Year-on-year changes eliminate seasonality, but individual unit root tests suggest that not all the variables are stationary. Nevertheless, SVAR analysis will be presented with year-on-year changes of the variables below, as it is suspected that the nonstationarity of the variables is likely due to the small sample size. This is confirmed by our estimates, as all the impulse responses from the SVAR converge to zero, indicating stationarity of the VAR system.

The identifying restrictions reflect both theoretical and practical considerations. Structural shocks are identified by imposing the following restrictions on contemporaneous relationships between the variables in the SVAR: ${ }^{1,2}$

$\begin{array}{cccccccc} & \Delta i & \Delta m & \Delta c p i & \Delta i p & \Delta o i l & \Delta f f & \Delta \text { neer } \\ \Delta i & 1 & c_{12} & 0 & 0 & c_{15} & 0 & c_{17} \\ \Delta m & c_{21} & 1 & c_{23} & c_{24} & 0 & 0 & c_{27} \\ \Delta c p i & 0 & 0 & 1 & c_{34} & c_{35} & 0 & 0 \\ \Delta i p & 0 & 0 & 0 & 1 & c_{45} & 0 & 0 \\ \Delta o i l & 0 & 0 & 0 & 0 & 1 & 0 & 0 \\ \Delta f f & 0 & 0 & 0 & 0 & c_{65} & 1 & 0 \\ \Delta \text { neer } & c_{71} & c_{72} & c_{73} & c_{74} & c_{75} & c_{76} & 1\end{array}$

where $i$ and $f f$ represent the nominal deposit rate and nominal FF rate and $m$, cpi, ip, oil, and neer represent the logarithms of broad money, core consumer price inflation ,the oil price, and the NEER (with an increase reflecting a depreciation), respectively. The $\Delta \mathrm{s}$ represent 12 -month changes of the variables. This identification approach broadly follows Kim and Roubini (2000). The restriction of no contemporaneous dependence of inflation on the exchange rate is motivated by the delayed pass-through of exchange rate movements on domestic prices.

This identification scheme reflects some salient features of the Russian economy. First, it recognizes the dollarization of the economy - albeit declining — and assumes that the opportunity cost of holding money and, thus, money demand growth depends contemporaneously on the change in the exchange rate. ${ }^{3,4}$ Second, unlike in Kim and Roubini (2000), interest rate shocks are not interpreted as monetary policy shocks. Given their need for funds, banks are assumed to adjust nominal deposit rates in response to money demand growth (with a negative sign), oil prices growth (with a negative sign), and NEER growth (with a positive sign).

\footnotetext{
${ }^{1}$ This approach contrasts with the standard Cholesky decomposition approach in which contemporaneous relationships between the variables of VAR are imposed by the ordering of the variables in the VAR (i.e., by assuming the contemporaneous coefficient matrix is lower triangular). The exact identification of SVAR requires $n(n-1) / 2$ restrictions. The model we estimated here has four additional restrictions. The likelihood ratio test with a $p$-value of 0.12 suggests that the over identifying restrictions are not rejected at the 10 percent level.

${ }^{2}$ The SVAR methodology is presented in the Appendix.

${ }^{3}$ This assumption differs from Kim and Roubini (2000).

${ }^{4}$ The sensitivity of broad money - which includes ruble-denominated deposits, foreign currency-denominated deposits, and currency in circulation - with respect to the exchange rate is assumed to originate from the substitutability of ruble broad money vis-à-vis foreign currency cash. A similar argument was made by Oomes and Ohnsorge (2005)
} 
VAR contributes to the variance, or forecast error, of any other variable in the VAR. This approach will be used to investigate which factors have contributed most to the variance in inflation.

12. Estimated impulse responses are in line with theoretical predictions. For example, after a positive interest rate shock, which likely involves a concomitant increase in the returns on assets that are substitutes of money, money demand (broad money) growth and inflation decelerate significantly. Industrial production growth also decelerates, although the result is not statistically significant. The rate of ruble depreciation declines initially, suggesting faster appreciation on impact, but rises afterward. This pattern of exchange rate movements is consistent with the response to a contraction of monetary policy in small, open economies with relative flexible exchange rates and limited capital controls (Figure 2). Although positive interest rate shocks (proxied by an exogenous increase in the deposit rate) have a delayed impact on inflation in Russia, the estimated effect is very weak. In fact, the effect of a positive interest rate shock (a 1 percentage point increase in the deposit rate) on inflation reaches its maximum effect after 5 months, but at this point it is estimated to result in a decline in core CPI inflation of only 0.003 percentage point. The effect on core CPI inflation starts fading 15 months after the shock. This is consistent with the widely held notion that the interest rate transmission mechanism in Russia is very weak.

\section{Inflation appears to be most responsive to exchange rate shocks and surprise}

inflation shocks. Inflation is also responsive to supply shocks, but the effects tend to be smaller (Figure 3). The following are the responses of inflation to various shocks:

- A positive inflation shock yields an increase in inflation, with the effect reaching a peak 3 months after the initial shock and dying out after 15 months.

- An exchange rate (depreciation) shock triggers a pickup in inflation only 4 months after the shock, and attains its maximum impact after 11 months, pointing to delayed passthrough effects. ${ }^{10}$ The effect on inflation is also fairly persistent and dies out after almost two years.

\footnotetext{
${ }^{10}$ The finding that the pass-through from exchange rate growth to inflation is 4 months is also in line with the finding of Kwon and others (2004).
} 
Figure 2. Impulse Responses to a Positive Interest Rate Shock 1/
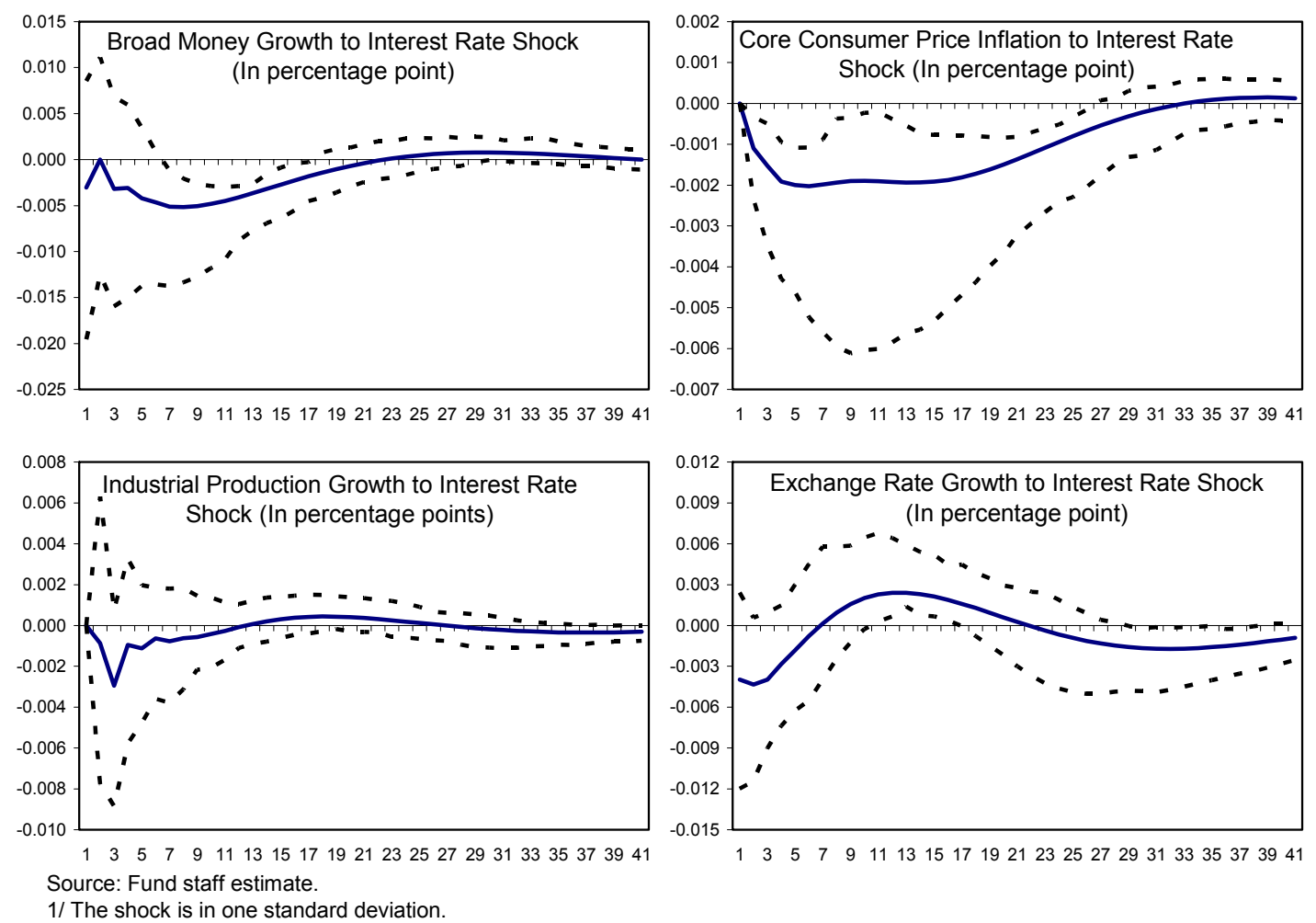

$1 /$ The shock is in one standard deviation.

Figure 3. Impulse Responses of Inflation to Shocks to Other Variables 1/
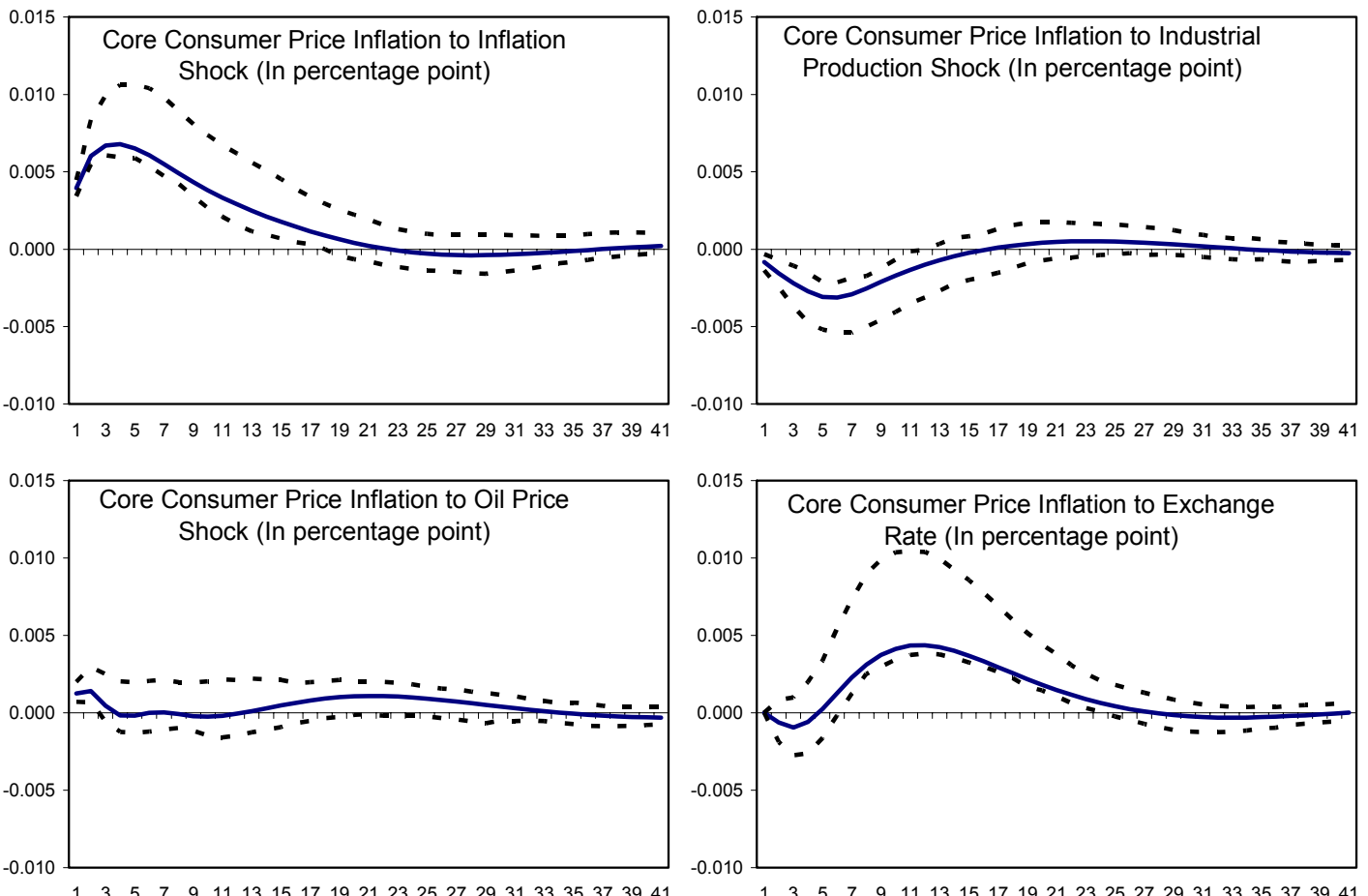
Source: Fund staff estimate.

$1 /$ All shocks are in one standard deviation.

\section{CInternational Monetary Fund. Not for Redistribution}


- A positive shock to industrial production growth, which can be interpreted as a positive supply shock, yields a decrease in inflation. The maximum effect occurs 5 months after the initial shock and the effect dies out after one year, pointing to delays in the impact of supply shocks on the economy.

- A positive oil price shock has an instantaneous impact on inflation, reflecting the direct effect of the oil price on production costs. While the immediate effect dies out quickly after 3 months, delayed effects reemerge almost a year later, likely capturing increases in disposable income (i.e., the positive terms of trade effect) and resulting increases in excess demand. ${ }^{11}$ Models in the literature include oil prices to account for inflationary expectations and negative supply shocks. However, since Russia is an oil exporter, it is obvious the effect of oil prices is inflationary but not recessionary, as confirmed by the positive impulse response of industrial production to an oil price shock.

\section{Variance decomposition also suggests that surprise inflation and exchange rate} shocks are the key determinants of inflation in Russia. SVAR analysis provides a decomposition of the forecast errors of variables into shocks of the components of the VAR. The contribution of VAR component shocks to inflation forecast errors is presented in Table 3. The most important source of inflation variability, measured in terms of contribution to forecast errors, is the identified surprise inflation shocks. ${ }^{12}$ Exchange rate shocks explain about onefourth of inflation variability.

Table 3. Forecast Error Variance Decompositon of Core Inflation

\begin{tabular}{rrrrrrrr}
\hline & Interest Rate & Broad Money & $\begin{array}{c}\text { Core Consumer } \\
\text { Price Inflation }\end{array}$ & $\begin{array}{c}\text { Industrial } \\
\text { Production }\end{array}$ & Oil Price & FF Rate & NEER \\
\hline Months & & & & & & & \\
1 & 0.00 & 0.00 & 0.88 & 0.04 & 0.09 & 0.00 & 0.00 \\
12 & 0.07 & 0.09 & 0.58 & 0.10 & 0.01 & 0.00 & 0.15 \\
24 & 0.09 & 0.08 & 0.47 & 0.08 & 0.02 & 0.02 & 0.24 \\
36 & 0.09 & 0.08 & 0.47 & 0.08 & 0.02 & 0.02 & 0.23 \\
\hline
\end{tabular}

\footnotetext{
${ }^{11}$ The delayed effect, however, is not statistically significant, even at the 10 percent level.

${ }^{12}$ This shock can be interpreted as a cost-push shock since the equation is meant to describe the supply side of the economy.
} 


\section{Concluding Remarks}

\section{Inflation in Russia is more persistent than in many other emerging market}

economies. This appears to be a reflection of strong backward-looking behavior in price setting. The identified backward-looking component in the inflation process might reflect the CBR's limited commitment to disinflation against the backdrop of a policy that limits nominal exchange rate appreciation. An explicit inflation-targeting framework may help reduce firms' uncertainty about the future. This, in turn, may allow firms to be more forward looking, thereby reducing persistence.

16. The exchange rate is the CBR's main policy instrument for controlling inflation. Allowing more nominal appreciation would help to keep inflation on a downward path and better anchor inflation expectations. This continued appreciation would eliminate the inflationary bias in the current monetary policy framework, in which the official inflation target is often subordinated to a policy of limiting nominal exchange rate appreciation. 


\section{APPENDIX: Estimation Methodologies}

\section{The new Keynesian Phillips curve}

17. The NKPC is estimated using the generalized method of moments (GMM). The GMM is based on the fact that, under rational expectations, the forecast error of inflation is uncorrelated with information dated $t-1$ and earlier. The following orthogonality condition is used to implement the estimation:

$$
E_{t-1}\left[\left(\pi_{t}-\lambda \cdot M C_{t}-\gamma^{f} E_{t} \pi_{t+1}-\gamma^{b} \pi_{t-1}\right) \cdot z_{t-1}\right]=0
$$

where $z_{t-1}$ is a vector of variables dated $t-1$ and earlier.

18. The data used in the estimation of the NKPC start in 2000 using monthly data. This choice reflects our desire to analyze a relatively stable period. Since the GDP deflator is not available with a monthly frequency, monthly change of the PPI is used as a measure of inflation. The other variables that are used in the estimation are the seasonally adjusted monthly industrial production index, the core consumer price inflation, the real unit labor cost index, and the real effective exchange rate. The latter two variables are used to approximate the marginal cost of production.

19. The instrument set consists of lags of PPI inflation, core consumer price inflation and either the output gap or the marginal cost of production. The following steps were taken to test the validity of marginal cost of production in the estimation:

- Many recent papers find that using the output gap in the Phillips curve estimation yields a negative coefficient for this variable. These papers advocate the use of some measure of the marginal cost of production in lieu of the output gap since (i) the marginal cost appears in the original theoretical formulation and (ii) it may be difficult to obtain a correct measure of the output gap. For example, the output gap measure obtained using the Hodrick-Prescott filter is criticized because it assumes that trend output evolves smoothly; this may not be the case in reality, particularly for transition countries.

- We first estimated the NKPC using the output gap and confirmed that the prediction of a negative output gap coefficient holds for Russia. We constructed the output gap by applying a quadratic trend to the monthly industrial production index. The results indicate that the output gap coefficient is negative and, therefore, cannot be used as a measure of economic activity.

- We next estimated the NKPC using the marginal cost of production. The income share of labor, generally used in the literature to measure the marginal cost of production, is not available with a monthly frequency. Instead, detrended real unit labor cost index is used as a proxy for the marginal cost of production. 


\section{Structural VAR estimation}

20. Kim and Roubini (2000) show that reduced-form residuals are linked to the structural shocks by the contemporaneous coefficient matrix in the structural form. SVAR assumes that the economy is characterized by the following SVAR model:

$$
\begin{aligned}
& B(L) y_{t}=\varepsilon_{t} \\
& \operatorname{var}\left(\varepsilon_{t}\right)=D,
\end{aligned}
$$

where $y_{t}$ is the vector of variables, $\varepsilon_{t}$ is the structural errors vector, and $B(L)$ is a matrix polynomial in the lag operator $L$. It can be shown that the reduced-form residuals, $u_{t}$, are linked to the structural shocks by the following formula:

$$
\varepsilon_{t}=B_{0} u_{t}
$$

where $B_{0}$ is the contemporaneous coefficient matrix in the structural form.

21. The identifying scheme discussed in this chapter imposes restrictions on $B_{0}$. In particular, the following restriction is imposed:

$$
\left[\begin{array}{c}
\varepsilon_{i} \\
\varepsilon_{m} \\
\varepsilon_{c p i} \\
\varepsilon_{i p} \\
\varepsilon_{\text {oil }} \\
\varepsilon_{f f} \\
\varepsilon_{\text {neer }}
\end{array}\right]=\left[\begin{array}{ccccccc}
1 & c_{12} & 0 & 0 & c_{15} & 0 & c_{17} \\
c_{21} & 1 & c_{23} & c_{24} & 0 & 0 & c_{27} \\
0 & 0 & 1 & c_{34} & c_{35} & 0 & 0 \\
0 & 0 & 0 & 1 & c_{45} & 0 & 0 \\
0 & 0 & 0 & 0 & 1 & 0 & 0 \\
0 & 0 & 0 & 0 & c_{65} & 1 & 0 \\
c_{71} & c_{72} & c_{73} & c_{74} & c_{75} & c_{76} & 1
\end{array}\right]\left[\begin{array}{c}
u_{i} \\
u_{m} \\
u_{c p i} \\
u_{i p} \\
u_{o i l} \\
u_{f f} \\
u_{\text {neer }}
\end{array}\right],
$$

where subscripts $i, m$, cpi, ip, oil, ff, and neer represent the deposit rate, broad money, core consumer price inflation, oil prices, the FF rate, and the nominal effective exchange rate. 


\section{REFERENCES}

Abiad, A., D. Leigh, and S. Fabrizio, 2005, Hungary: Selected Issues, IMF Country Report No. 05/215 (Washington: International Monetary Fund).

Banerji, Angana, and others, 2003, Russian Federation: Selected Issues, IMF Country Report No. 03/146 (Washington: International Monetary Fund).

Calvo, G.A.,1983, "Staggered Prices in a Utility-Maximizing Framework," Journal of Monetary Economics, Vol. 12 (September), pp. 383-98.

Celasun, Oya, Gaston Gelos, and Alessandro Prati, 2003, "Would 'Cold Turkey' Work in Turkey?” IMF Working Paper 03/49 (Washington: International Monetary Fund).

Gali, Jordi, and Mark Gertler, 1999, "Inflation Dynamics: A Structural Econometric Analysis," Journal of Monetary Economics, Vol. 44 No. (2), pp. 195-222.

Kim, Soyoung, and Nouriel Roubini, 2000, "Exchange Rate Anomalies in the Industrial Countries: A Solution with a Structural VAR Approach," Journal of Monetary Economics, Vol. 45 (June), pp. 561-86.

Kwon, Goohoon, and others, 2004, Russian Federation: Selected Issues, IMF Country Report No. 04/316 (Washington: International Monetary Fund).

Oomes, Nienke, and Franziska Ohnsorge, 2005, "Money Demand and Inflation in Dollarized Economies: The Case of Russia," IMF Working Paper 05/144 (Washington: International Monetary Fund). 


\section{Benchmarking The Efficiency of Public Expenditure IN THE RUSSIAN FEDERATION ${ }^{13}$}

\section{A. Introduction and Summary}

\section{The rapid increase in government revenue in the Russian Federation offers a} unique opportunity to improve public services if the resources are allocated well. The analysis in IMF (2006) demonstrated the existence of room for fiscal easing from a long-term sustainability perspective. The authorities plan to direct a large part of the additional resources - in particular those associated with the oil windfall - toward the social sectors. This emphasis is appropriate, as improvements in public health and education services and in social protection can increase welfare and potentially also economic growth. However, higher spending alone will not deliver improvements in outcomes, as ample anecdotic and empirical evidence from other countries suggests. ${ }^{14}$ It is essential that large increases in public expenditure be accompanied by an improvement in its efficiency, that is, the effect this expenditure has on the intended policy outcomes. This study aims to contribute preliminary analytical underpinnings to reforms aimed at enhancing expenditure efficiency.

23. The study examines the efficiency of public spending on health, education, and social protection at the general and local government levels in the Russian Federation. The focus on these three functional expenditure categories (in line with most of the literature) is due to the availability of data on public sector performance. Substantial conceptual problems notwithstanding (see Section B), internationally comparable measures of the outcomes of public sector activity in these sectors are available, such as the number of hospital beds, university enrollment, or income inequality; no such indicators are available for other key spending areas, particularly administration and capital spending. Efficiency is measured by the ratio of outcome measures to public spending. Obviously, other factors than public spending also influence outcomes. While the most important two factors, the economy's per capita income level and private health and education spending, will be controlled for, the results still must be interpreted with great care.

24. The results provide preliminary evidence of substantial room for improving public expenditure efficiency. At the general government level, cross-country comparisons suggest that, while efficiency in education seems to be relatively high, the current outcomes in health and social protection could be produced with only about two-thirds of the present spending. At the local government level, comparing spending and outcomes across regions suggests that, on average, the current outcomes in health, education, and social protection could again be produced with about two-thirds of the present inputs if the less efficient regions would emulate

\footnotetext{
${ }^{13}$ Prepared by David Hauner (FAD).

${ }^{14}$ For example, Aninat, Bauer, and Cowan (1999) refer to the Chilean experience, where a tripling of real health spending over a few years did not produce any visible or measurable increase in the quantity or quality of services. All cross-country studies cited in this paper show that higher spending often fails to produce better outcomes.
} 
the more efficient ones. An econometric analysis of regional efficiency differences suggests that higher efficiency tends to be associated, in particular, with higher per capita income, a smaller share of federal transfers in local government revenue, better governance, a stronger civil society, and less public expenditure. A better understanding of these drivers of efficiency can be useful not only because local governments account for about half of general government spending, but also because the underlying determinants of expenditure efficiency are likely to be similar at the central government level. While these results should be interpreted with caution and seen only as first indications of possible inefficiencies, they suggest several policy implications.

25. Vigorous reform in the social sectors, particularly of health care financing and the targeting of social assistance, would strengthen efficiency. The excessively complicated health care financing system could be simplified and made more incentive compatible through single source funding, outcome-based financing, and performance-pay. Ill-targeted housing, utilities, and energy subsidies, as well as social assistance programs, could be subjected to much broader and tighter means testing, which would also free up funds for the truly vulnerable, who currently receive only a very small part of the benefits. In education, relatively favorable efficiency should not conceal the need to improve quality, including through higher pay for teachers. This pay raise, however, could be accompanied by more emphasis on performance and school restructuring. The quality of spending of federal transfers by the regions ought to be monitored more closely.

26. The paper proceeds as follows: it discusses methodological issue (Section B); explores the efficiency of public spending on health, education, and social protection in the Russian Federation on the general government level (section $\mathrm{C}$ ), as well as on the local government level (Section D); and draws conclusions (Section E). Appendix I elaborates on the methodological underpinnings and Appendix II on the results by region.

\section{B. Methodological Issues}

27. The efficiency of public spending is the subject of a rapidly growing literature. Tanzi and Schuknecht (1997 and 2000) explore the benefits from public spending in industrial countries. Gupta and Verhoeven (2001) evaluate education spending in Africa. Afonso, Schuknecht, and Tanzi (2005) develop encompassing public sector performance and public sector efficiency indicators and apply them to OECD countries. Afonso, Schuknecht, and Tanzi (2006) examine spending efficiency in the new member states of the European Union. Herrera and Pang (2005) explore the efficiency of public spending in a large set of developing countries. Several country case studies, such as Mattina and Gunnarsson (2006), complement these cross-country papers.

28. The efficiency of public spending is measured by comparing actual spending with the minimum spending theoretically sufficient to produce the same actual output. The efficiency of an input-output combination is measured relative to a production possibilities frontier constructed with data envelopment analysis (DEA), a nonparametric method. Given the focus on efficient spending, the input approach is used. In this context, the efficiency scores 
measure the share of the actual spending sufficient to produce the actual output if a given country's public sector were as efficient as the best; for example, a score of 0.7 implies potential savings of 30 percent. Note that thus defined efficiency is only an upper bound of the "true" efficiency, because the producers who perform the best may still have room for improvement. DEA has been widely used in efficiency measurement, particularly in the services industries, because it does not require the assumption of a particular functional form, deviations from which are misinterpreted as inefficiency by parametric techniques. However, cautious sample selection is crucial, as DEA interprets random errors as inefficiency and is thus sensitive to outliers; it is also sensitive to the degrees of freedom. See Appendix I for further methodological details.

\section{Inputs are measured by public spending in specific functional areas, while outputs} are represented by indicators of the impact of public spending in these areas. While spending data are relatively harmonized, there are complex issues relating to the taxation of social benefits in some countries or the accounting of the imputed cost of government property. On the output side, relatively consistent cross-country data are available for spending outcomes in education, health, and social protection. Health outcomes are measured by indicators such as infant mortality and the number of hospital beds. Education outcomes are measured by teacherpupil ratios, tertiary enrollment, and test scores. Data availability is more limited for social protection, where the Gini coefficient of income inequality that is used, is admittedly a relatively weak indicator. Most of these indicators are proxies, not actual measures of outcomes; for example, teacher-student ratios proxy education outcomes, assuming they are correlated with quantity and quality of teaching. Moreover, while the indicators and resulting efficiency scores, tend to be highly correlated (Herrera and Pang, 2005), indicator selection affects results to some extent. Another limitation is that much of the data are available only at irregular frequencies; we follow Afonso, Schuknecht, and Tanzi (2005) in using the most recent observation, as most series show little yearly variation.

\section{While efficiency scores give useful hints of potential inefficiencies, they must be} interpreted with great care and should be combined with qualitative information. This is because the approach for calculating the scores assumes homogeneity across countries in the production functions. Two of the most obvious violations of this assumption - the Baumol effect (production costs in the public sector tend to rise faster than per capita income) and the heterogeneity in input quality - are here controlled for by using per capita income at purchasing power parities. Another obvious comparability issue - the different amounts of private

spending on health and education - is controlled for as far as data availability permits. ${ }^{15}$ In any case, no number of controls can substitute for careful interpretation of the DEA results.

\footnotetext{
${ }^{15}$ Among several valid approaches to including control variables in DEA — which tend to yield similar results (Worthington and Dollery, 2002) — we choose to use input variables, as this allows direct comparison of the efficiency scores with and without controls.
} 


\section{For local governments, public sector performance (PSP) and public sector} efficiency (PSE) scores can be computed. The scores computed in this chapter were first proposed by Afonso, Schuknecht, and Tanzi (2005). PSP is defined as the mean of the outcome indicators (by sector or all together), standardized by dividing each observation by the respective indicator's standard deviation and dividing by the mean. PSE is then given by the ratio of PSP to the respective spending in percent of GDP. While these indicators are very concise, there is no doubt that the required weighting of the outcome indicators introduces additional assumptions, in addition to those discussed above. Again see Appendix I for more methodological detail.

\section{General Government ${ }^{16}$}

\section{Relative to GDP, general government expenditure in the Russian Federation is} moderate, particularly on education and social protection. As Figure 1 shows, total expenditures in percent of GDP are lower than in all transition countries included in the sample, except Kazakhstan. Public expenditure is also moderate compared with the countries of similar income level. ${ }^{17}$ With regard to the three social sectors, the Russian Federation spends less on education and social protection than all countries except Kazakhstan; it is more in line with other countries in health, although remaining at the lower end of the distribution.

\section{Also, after accounting for the overall size of government, expenditure on} education, health, and social protection is relatively small. The shares of health and education in total expenditure are smaller than in most other transition countries, and the share of social protection is the third smallest after Kazakhstan and Latvia (Figure 2). In contrast, at about one-fifth, the combined share of defense and public order and safety is larger than in any other of the benchmark countries. Also the economic classification (Figure 3) shows low shares of social benefits relative both to GDP and total expenditure; the wage bill is also moderate.

\section{However, poorly targeted subsidies for housing, utilities, and energy remain} unusually large. The fiscal cost of discounted housing and utilities for "privileged citizens"18 is more than 2 percent of GDP. Moreover, the additional quasi-fiscal cost borne by the stateowned providers is estimated to amount to 2 percent of GDP (World Bank, 2004). These subsidies are very poorly targeted: "housing privileges" amount to almost six times the spending on targeted social assistance, despite World Bank (2004 and 2005) analysis suggesting that most of these privileges accrue to upper-income households; meanwhile, the

\footnotetext{
${ }^{16}$ The data sources for this section are WHO Statistical Information System (health outcomes and private and public spending); UNESCO Global Education Digest (education outcomes and public spending); IMF Government Finance Statistics (other fiscal data); and IMF World Economic Outlook database (macroeconomic data). For the Russian Federation, data from these sources were in some cases replaced with national statistics.

${ }^{17}$ The share of public expenditure in GDP tends to rise because productivity growth in the public sector is often slower (Baumol effect), and because the demand for public services rises as societies develop (Wagner effect).

${ }^{18}$ As a relic of Soviet times, privileged citizens (civil servants, soldiers, etc.) receive discounted housing.
} 
means-tested "housing allowances" could be used to take care of vulnerable groups. Moreover, not only are housing subsidies allocated inefficiently, but they also entail little competition, poor service, and underinvestment in the respective sectors. As a first step to their abolishment, the privileges could be monetized. More progress has already been made in the reform of energy subsidies, where gas and wholesale electricity prices are set to be adjusted gradually to market prices until 2011; however, it remains unclear to what extent electricity prices for households will rise.

\section{In this paper, social expenditure in the Russian Federation is related to outcome} indicators and compared with other countries to assess its efficiency. The choice of the indicators is in line with the literature (see Section B). The sample consists of countries with comparable income levels and transition economies of all income levels. For each sector (health, education, and social protection), DEA is first run with one input (expenditure in percent of GDP) and one output. Inputs and outputs are shown in Figures 4-7, with the DEA scores reported next to the country acronyms. The countries with a score of 1 form the efficient frontier; for the other countries, the scores indicate the spending sufficient to produce the same outcome, relative to the frontier at the left of the country. For each sector, DEA is then also run with multiple inputs and outputs, with results reported in Tables 1-3.

36. For health, the results consistently suggest that it would be possible to produce the same outcomes with only 60-70 percent of current spending. As Figures 4-5 show, all single-output models find an efficiency level of 0.6 , with the exception of "physicians per 1,000 population," where the efficiency level is $0.7 .{ }^{19}$ All figures include private health spending to adjust for the considerable differences in health care financing, which are much more pronounced than in the education sector. The multiple-output model in Table 1 confirms these findings: not controlling for income per capita (but for private health spending) yields an efficiency score of 0.65 , while controlling for income per capita raises the score to 0.72 .

\section{While the country's health problems are only partly related to the health care} system, there is still great need for reform. ${ }^{20}$ The current financing is excessively complicated, as the federal and regional medical insurance funds are complemented by federal and regional budget financing. This setup establishes weak budget constraints for the funds and reduces their incentives to monitor providers. Moreover, the budget funding, accounting for about 60 percent, is usually input, as opposed to output based and thus creates incentives for excessive hospital capacity, as opposed to more cost-effective outpatient care. Also, the private and public insurance companies that were intended to create competition rarely fulfill this function, because insurers tend to be chosen by the employer (often with little regard to performance), and providers are usually operated by the municipalities. The insurers bear little risk but create administrative costs of about 3 percent by acting as mere intermediaries.

\footnotetext{
${ }^{19}$ In a sample of all developing economies, Herrera and Pang (2005) found for the Russian Federation also efficiency scores of about 0.6 in health, using life expectancy and immunization as outcome indicators.

${ }^{20}$ See Marquez (2005) and OECD (2006) for more detail on problems and reforms in the health care system.
} 
38. Health care financing could be simplified and made more incentive-compatible. The 2005 health care strategy rightly emphasizes genuinely insurance-based and output-based funding, as well as more cost-effective primary care. A pilot project in 20 regions, including single-source funding, outcome-based financing, and performance pay, could be made permanent and universal. Also, the establishment of "autonomous institutions" is intended to provide many medical facilities with global budgets and incentives for better financial management. While insufficient payroll tax revenue and regional income disparities require continued budgetary financing, channeling them through the medical funds would at least streamline the system. The choice among the insurance companies could be given to the employees; the insurers could become actual risk bearers; and they could be limited to supplementary insurance, as is already done in some regions. Co-payments, which could be progressive, would also improve efficiency in some areas, particularly in pharmaceuticals where spending is unusually high. Also, the funds could leverage their market power more to make the pharmaceuticals market more competitive. Finally, more emphasis could be put on combating corruption, including by establishing independent complaints offices.

39. In education, efficiency appears to be substantially higher than in health, particularly in secondary and tertiary education. With regard to these latter, the Russian Federation obtains efficiency scores of 1 (Figure 6), because enrollment ratios and literacy rates similar to advanced economies are achieved with relatively little expenditure. However, efficiency is somewhat lower with regard to primary (including preprimary) education and test scores, ${ }^{21}$ of 0.7 and 0.8 , respectively. ${ }^{22}$ This outcome is in line with evidence of overstaffing in (pre-)primary education, mostly because many schools in rural areas are small, and of problems with education quality, which continues to lag most of the advanced economies (World Bank, 2007). Overall, however, the multiple-output model (Table 2) suggests that education spending is relatively efficient, whether controlling for income level or not.

40. However, the apparently high efficiency of education spending masks quality problems that are insufficiently captured by the efficiency measure used here. First, teacher qualification and motivation are eroded by salaries that are only half as high as on average as those in advanced economies, when evaluated relative to per capita GDP. Raising salaries relative to the national average is thus certainly justified, but this should be accompanied by more emphasis on performance. Second, general government figures conceal the fact that too few teachers in urban areas are accompanied by too many in rural areas, an interpretation confirmed by substantial inefficiency found at the regional level (see next section); school restructuring should thus be a focal point of reform. Third, tertiary education benefits from substantial private tuition fees, but the resulting quality is questionable,

\footnotetext{
${ }^{21}$ Given data availability, many of the benchmark countries in test scores are advanced economies.

${ }^{22}$ In a sample of all developing economies, Herrera and Pang (2005), found for the Russian Federation efficiency scores of about 0.85 for primary school enrollment, about 0.73 for secondary school enrollment, and 0.93 for test scores (including advanced economies).
} 
considering that 75 percent of graduates do not find jobs in their field. More autonomy for tertiary education institutions and more incentives for links with the business sector could alleviate this problem. Finally, the gradual introduction of per capita financing ("money follows the student") should significantly raise the efficiency of education spending.

\section{In the area of social protection, results also suggest considerable room for} improving efficiency. ${ }^{23}$ The output model (Figure 7) results in an efficiency score of only 0.5 . Controlling for per capita income lifts the score to 0.75 (Table 3). Note that income inequality - the outcome measure used - is conceptually problematic: poverty rates would have been a more adequate measure, but limited cross-country data availability prevents its use.

\section{Means testing could improve poor targeting of social protection expenditure. ${ }^{24}$}

Spending on social assistance programs targeted to the poor is merely about $1 / 2$ percent of GDP, while the fiscal cost of various privileges (see above) is much higher. Even the programs aimed at the poor are ill targeted: best targeted are the child allowance and the decentralized social assistance programs, but these still reach only about 30 and 28 percent, respectively, of their beneficiaries from the poorest quintile. About half of the beneficiaries of the targeted social assistance programs come from the upper 60 percent of the income distribution. With the exception of the child allowance, the average benefit received by the richest quintile is larger than the average benefit received by the poorest quintile. The share of social assistance funds captured by the poorest quintile is also smaller than in most other transition economies.

\section{Local Governments}

43. Local governments account for the bulk of social expenditures at the regional level. Local governments are defined here as the consolidated subfederal governments of each of 79 regions. ${ }^{25}$ Inputs are given by the health, education, and social protection expenditure of the consolidated governments in each region (regional and municipal budgetary authorities and extrabudgetary funds). To the extent that outcomes are affected by both federal and local government spending, one requires the assumption that the contribution of federal spending to outcomes is the same in all regions, as data on federal spending per region are not available. However, any bias should be small, as the public expenditure related to the selected outcome indicators is overwhelmingly disbursed by local governments. Local governments account for about 85 percent of health and about 80 percent of social protection expenditure. In education, they account for nearly all preschool and general education spending and about 65 percent of professional education spending. However, while local governments disburse these funds, policies are often set at the federal level.

\footnotetext{
${ }^{23}$ Given data availability, many of the benchmark countries are advanced economies.

${ }^{24}$ See World Bank (2004) for more detail.

25 There are 21 republics, 50 oblasts, 6 krais, 10 okrugs, and the cities of Moscow and St. Petersburg. For simplicity, all of them are here referred to as "regions," including the okrugs in superior entities gives $N=79$.
} 
44. Local government expenditure varies substantially relative to gross regional product (GRP), and it appears to bear a negative relationship to per capita income. Figure 8 shows that local government spending in most regions varies between about 15-25 percent of GRP, but is substantially higher in several regions. These differences also translate into large variations in social spending. Health expenditure varies mostly between 2 and 4 percent of GRP, but can extend to 15 percent. Education spending varies mostly between 3 and 5 percent of GRP, but can extend to 20 percent; and social protection expenditure varies mostly between 1 and 3 percent of GRP, but can extend up to 9 percent. There is also a negative relationship between the size of local government spending and income level, suggesting that there are no Baumol and Wagner effects (see footnote 13) for Russia' regions; rather, expenditure is similar in nominal terms due to the equalization transfers.

\section{Local government expenditure is evaluated using different measures of} performance and efficiency. Specifically, these are the public sector performance (PSP), public sector efficiency (PSE), and data envelopment analysis (DEA) efficiency scores, respectively, for health, education, and social protection, and for all these three social sectors together. The outcome indicators are similar to those used for general government: hospital beds and physicians relative to population; infant mortality; life expectancy; preschool and professional education coverage; teacher-student ratios in general and professional education; incidence of poverty; and income inequality. The results summarized in this section are based on the data described in Table $4 .^{26}$ The complete scores by region are listed in Table A1 in Appendix II.

\section{The most striking finding is that the large variation of expenditures across regions} results in very similar outcomes (Figure 9). As mentioned before, local government spending in percent of GDP, shown on the $x$-axes in the figure, varies considerably across regions. However, the different spending does not seem to translate into materially different outcomes, as the PSP scores shown on the $y$-axes in the left part of the figure suggest: whether it is health, education, or social protection, outcomes are similar, regardless of the associated level of expenditures. Comparing the actual production sets with those on the frontier to the left indicates visually the large efficiency differences between regions. Therefore, PSE and DEA scores for all three sectors are negatively related to the level of spending, as shown in the right part of the figure.

47. Statistical measures also underscore the contrast between the small variation in public sector performance and the much larger one in public sector efficiency. Table 5 summarizes the scores based on several descriptive statistics and the Spearman rank order correlation test. PSP has no meaning as an absolute number, but again it is notable how little PSP varies across regions, with a coefficient of variation of only $0.10-0.17$, compared with

\footnotetext{
${ }^{26}$ All data are from Rosstat (2006), unless otherwise mentioned. As most time series are highly persistent, only the latest observation is used, in most cases for 2004; for series with larger variance, multiple-year averages are used.
} 
0.38-0.42 for PSE. However, minimum and maximum PSP still reveals a remarkably wide range: $0.60-1.30$ in health, $0.64-1.24$ in education, $0.72-1.65$ in social protection, and $0.74-$ 1.33 in the social sectors overall; in other words, in each of the three social sectors, public sector performance is about twice as good in the best as in the worst region. The rank correlations reveal that regions that perform better in education also do so in health, with a highly statistically significant correlation of 0.5 ; between social protection and health and between social protection and education, are weaker than that.

48. The DEA scores suggest that the average region could produce the same outcomes with only 64 percent of the actual spending. This result is fairly consistent across sectors, with a mean of about 0.62 in health and social protection and 0.68 in education. This result is similar to the mean of 0.59 that Afonso, Schuknecht, and Tanzi (2006) found for emerging markets, but much worse than the average 0.79 that Afonso, Schuknecht, and Tanzi (2005) found for the OECD. Note again that efficiency is always assessed relative to the best observed practice, which could still be worse than the theoretical optimum. The two types of efficiency scores - PSE and DEA - behave very similarly, with highly significant rank order correlations of 0.54 in health, 0.77 in education, 0.92 in social protection, and 0.82 overall.

49. Of course, exogenous factors may partly explain the differences in outcomes. Some possible explanations are examined econometrically below. A better understanding of these drivers of efficiency can be useful not only because local governments account for about half of general government spending, but also because the underlying determinants of efficiency are likely to be similar at the federal level. The possible explanatory factors that are examined are described in Table 4, and their motivation is discussed in Box 1. The factors fall into five broad categories (social and environmental conditions, relationship to the federal government, quality of governance, civil society, and public and private expenditure). Table 6 summarizes the results of three distinct regression approaches for each of the twelve scores. ${ }^{27}$ The regressions explain a large part of the variation, with an adjusted $R$-squared of $0.55-0.80$ in eight of the twelve regressions, and still $0.34-0.36$ in another three.

\footnotetext{
${ }^{27}$ Univariate and multivariate regressions are used because both have disadvantages: the former, in which a constant is also included, suffers from omitted-variable bias, the latter from multicollinearity. As a third approach, the multivariate regressions are tested down to the specifications that maximize the adjusted $R$-squared. To be conservative, conclusions are drawn only if (i) the coefficients in at least two of the three approaches are statistically significant, and (ii) all of these significant coefficients have the same sign. More detail on methodological issues is can be found in Appendix I. The individual regressions are shown in Appendix II.
} 


\section{Box 1. Explanatory Variables-Motivation and Results}

Social and environmental conditions. A higher income per capita (INCPERCAP) could, on the one hand, reduce efficiency by raising the relative cost of public services (Baumol, 1967). On the other hand, higher income has consistently been found to be associated with better health and education outcomes (Afonso and St. Aubyn, 2006; Afonso, Schuknecht, and Tanzi 2006; Herrera and Pang, 2005). To the extent that higher INCPERCAP reduces poverty and inequality, it would also directly contribute to better social protection outcomes. The evidence here lends more support to the second hypothesis: higher INCPERCAP is consistently associated with higher PSE in all three social sectors. In fact, it even explains between one-third and one-half of the variation in the univariate regressions.

A larger fuel industry $(F U E L)$ could, on the one hand, affect PSP similarly as INCPERCAP, but through additional nonlinear effects, as the few regions that pump Russia's fuel exports are unusually wealthy. On the other hand, it could also reduce outcomes at a given income level, as oil windfalls may weaken incentives in the public sector (Desai, Frinkman, and Goldberg, 2005). Alas, FUEL does not seem to affect health and education performance, but consistently raises social protection efficiency, suggesting that - everything else equal (particularly income and social protection expenditure) - regions with larger FUEL perform better regarding inequality and poverty.

The consumption of alcohol and tobacco $(A L C T O B)$ and the share of above-working-age population $(O L D)$ are expected to have obvious negative implications for health outcomes. Alas, there is no consistent evidence. However, $O L D$ has a consistent positive relationship with education performance and efficiency, suggesting that regions with fewer students are doing better at providing education.

Higher population density (DENSITY) and higher winter temperatures (TEMPJAN) are expected to improve PSE by reducing the cost of services provision through economies of scale and lower transportation and heating costs; moreover, warmer climate could be expected to improve health outcomes. However, the only robust finding here is a positive relationship between temperatures and social protection performance, suggesting that warmer regions do better in inequality and poverty.

Relationship to the federal government. The federal government retains a large degree of control over regional finances in Russia, as the center has a disproportionate sway over expenditure responsibilities and transfer rules. However, equalization has become more rules-based since the late 1990s (Dabla-Norris and Weber, 2001). The attention the federal government is paying to regional developments is thus potentially important to PSE. One popular measure of this attention by the center in the Russian context (e.g., Berkowitz and DeJong, 2003) is the distance from Moscow, which indeed has a consistent negative relationship with efficiency in education, social protection, and the social sectors overall.

Moreover, as it has been claimed that the Russian equalization system is largely determined by bargaining (Treisman, 1996) or is influenced by a region's impact on federal elections (Popov, 2004); larger POPULATION could increase per capita transfers and thus PSP. However, there is no consistent evidence for this variable.

A share of TRANSFERS in regional revenues is expected to reduce the incentives of local governments to spend efficiently (Ter-Minassian, 1997): first, the funds are not raised in their own region, and, second, there may even be an incentive to spend more to receive additional transfers. There is indeed strong evidence of such a negative relationship for health and the social sectors overall, but less so for education and social protection. In fact, TRANSFERS explains not less than about 60 percent of the variation in PSE for all three sectors. However, for social protection performance the relationship is positive; this apparent contradiction may be explained by the fact that social protection expenditure consists mostly of cash benefits that are relatively independent of local government effectiveness, thus allowing federal transfers to directly affect social protection outcomes.

Quality of governance. Lower quality of governance can be expected to reduce the $P S P$ and $P S E$. In the absence of more direct measures, two proxies are adopted: investment risk $(R I S K)$ is measured by a business survey that places a heavy weight on the quality of governance; and the share of the shadow economy (SHADOW) has been shown to be correlated with bad governance (Dabla-Norris, Gradstein and Schuknecht, 2005). In fact, it turns out that larger $S H A D O W$ is consistently associated with lower performance in health, social protection, and the social sectors overall, and also with lower efficiency in social protection. On the latter, RISK yields the same result, but it appears to be positively related to health performance and efficiency. 
Box 1. Explanatory Variables-Motivation and Results (concluded)

Civil society. Putnam (1993) and Gellner (1994) have argued that the degree of development of civil society influences the effectiveness of the public sector: cooperation between citizens and their formation of nonstate institutions enables them to exert more effective control over politicians and bureaucrats. La Porta and others (1997) empirically confirm such a positive correlation between participation in civic activities and government performance. Unfortunately, such data are unavailable for Russia's regions. However, two of the determinants of the degree of development of the civil society proposed by Putnam are available: citizens with higher education ( $A C A D E M I C)$ are likely to be better informed and more active politically, and urbanism (URBAN) may promote civic activity through clustering. Our results support these hypotheses, as $A C A D E M I C$ and $U R B A N$ are consistently positively correlated with most $P S P$ and $P S E$ scores. URBAN is a particularly influential variable, explaining about one-third of the variation in many univariate regressions.

Size of public and private expenditure in the relevant sectors. Larger public spending $(E X P H E L / \ldots)$ would be obviously expected to improve performance, as well as private health and education spending $(P R I V H E L / \ldots)$. Its relationship to efficiency is less clear a priori: it could be positive if increasing economies of scale prevail, or negative if declining marginal returns dominate. Private spending seems to have surprisingly little impact on health and education performance and education efficiency. There is, however, interesting evidence of a negative relationship between private health spending and the efficiency of public health expenditure. This relationship could be interpreted either as evidence that higher private spending allows lower public sector efficiency, or that lower public sector efficiency entails higher private spending (an endogeneity test in Appendix I supports the first hypothesis). On public spending, there is very consistent evidence of a negative relationship between the size of spending and efficiency across all sectors, and evidence of the expected positive relationship to performance only in social protection.

\section{Local Governments—Overview of Regression Results}

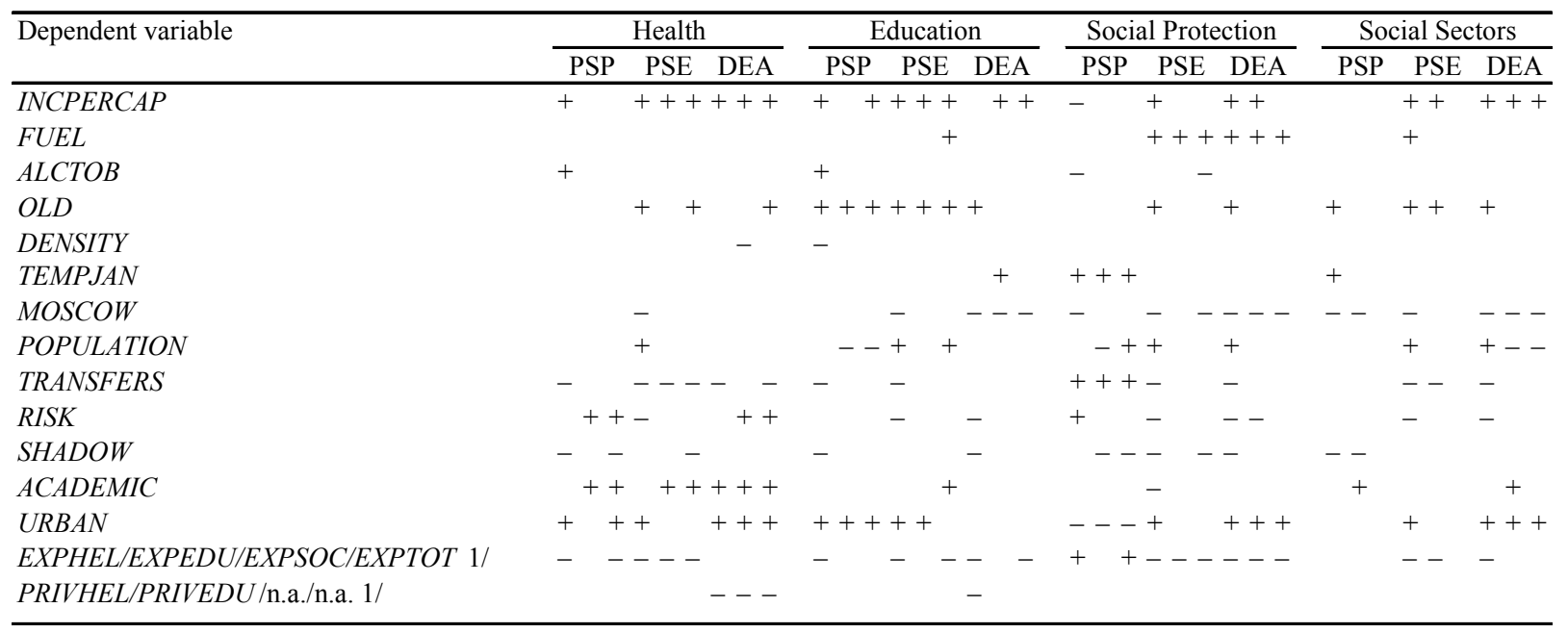

Source: Fund staff calculations.

Notes: Table shows the signs of the coefficients in Tables A2-A4 that are significant at least at the 10 percent level. The entries in each column follow the order of Tables A2-A4: univariate, multivariate, and tested-down regressions.

1/ The first, second, third, and fourth alternatives apply to the regressions for health, education, social protection, and all three social sectors, respectively. 
50. The regressions suggest that PSP and PSE are better in regions that are richer and have better governance and stronger civil societies (Box 1). ${ }^{28}$ Higher income per capita is consistently associated with higher PSE in all three social sectors; in fact, it tends to explain a particularly large share of the variation. Even controlling for this effect, regions with larger fuel sectors perform better regarding inequality. Moreover, better governance tends to improve PSP and PSE. Similarly, regions that have a more developed civil society (as proxied by the share of the urban population and tertiary graduates), which supposedly exerts stronger control on government activities, do better. Higher private health expenditure is associated with lower public expenditure efficiency. In contrast, there is little evidence that the intensity of alcohol consumption, the share of elderly people, climate, or population size and density explain much of the regional differences.

\section{A key finding is that adverse incentives provided by the intergovernmental}

transfer system seem to contribute to expenditure inefficiency. There is strong evidence that higher expenditure (relative to GRP) and larger shares of federal transfers in total revenue reduce expenditure efficiency. These points are related because poorer regions not only receive larger transfers but also spend more, as Figure 8 shows. Behind this result, are arguably two factors. One factor is that local governments have little incentive to spend less because they risk losing federal transfers or receive additional expenditure responsibilities (Ter-Minassian, 1997; and Zhuravskaya, 2000). If weak democratic control provides little motivation to deliver more than an absolute minimum of public services, any higher spending will thus necessarily result in lower efficiency. Also, governments in poorer regions appear to expand public employment to extract transfers (Gimpelson and Treisman, 2002). A second factor is that regional expenditures are driven primarily by the availability of revenues, with regions usually spending windfall revenues in booms rather than saving them (Kwon and Spilimbergo, 2005). The resulting expenditure volatility is likely to further reduce efficiency, similar to the effect documented in the context of external aid (Bulir and Hamann, 2005).

\section{While much progress has been made regarding intergovernmental relations,} the local governments still need better incentives to improve financial management. Since 2000, the responsibilities of the various levels of government have been clarified and unfunded mandates reduced. Recently, financial incentives for regions were established to improve financial management (including through performance and multiyear budgeting) and to meet performance criteria set for them by the federal government in education and health. Moreover, regions will be grouped in three tiers according to their dependence on transfers, with varying degrees of federal supervision, and all regions will have municipal governments with their own budgets. However, the deadline for the reforming the relations between regional and municipal

\footnotetext{
${ }^{28}$ These findings are in line with cross-country studies; e.g., Afonso Schuknecht, and Tanzi (2006) found higher expenditure efficiency to be positively related to income, civil service competence, education level, and property rights.
} 
governments has slipped to 2009. Moreover, weakening the local government budget constraint through frequent changes in tax attributions, as well as ad hoc federal interventions in expenditure responsibilities of lower government levels, is undesirable.

\section{E. Conclusion}

\section{The paper has examined the efficiency of social expenditure in the Russian} Federation on the general and local government levels. The findings suggest considerable room for improving efficiency, particularly in health care and social protection, but less so in education. Moreover, an examination of regional efficiency variations raises particular concerns about the efficiency of the spending of federal transfers by the poorer regions.

\section{Besides the more specific policy implications discussed in the paper, implementing} performance budgeting and extending more autonomy and accountability to local governments are key. Renewed efforts will be necessary to implement performance budgeting, which so far has fallen short of expectations: this kind of budgeting applies to only 15 percent of the federal budget - with poor outcomes - and even less progress has been made at the subfederal level. Moreover, local governments need to be granted more sway in policymaking in the domains of their expenditure responsibilities; they also need to be granted more accountability, including harder budget constraints. The National Projects are an example of ad hoc federal intervention that risks creating unfunded mandates and backtracks on prior steps taken toward devolution. Similarly, while shortcomings in financial management at the local government level may warrant more federal supervision, there is a risk that tightening control will in the long run only further weaken incentives for responsible policymaking and financial management. In contrast, the establishment of autonomous institutions with global budgets and incentives for competition both between public service providers and with the private sector could improve efficiency; however, financial risks for the government will have to be closely monitored. 
Table 1. General Government—Multiple-Outcome Health Efficiency Model

\begin{tabular}{|c|c|c|c|c|c|c|c|c|c|c|c|c|c|}
\hline \multirow[b]{2}{*}{ Country } & \multirow[b]{2}{*}{$\begin{array}{l}\text { Income per } \\
\text { Capita (U.S. } \\
\text { dollars, PPP) } \\
\end{array}$} & \multirow[b]{2}{*}{$\begin{array}{c}\text { Public Health } \\
\text { Expenditure } \\
\text { in Percent of } \\
\text { GDP }\end{array}$} & \multirow[b]{2}{*}{$\begin{array}{c}\text { Private } \\
\text { Health } \\
\text { Expenditure } \\
\text { in Percent of } \\
\text { GDP } \\
\end{array}$} & \multirow[b]{2}{*}{$\begin{array}{l}\text { Healthy Life } \\
\text { Expectancy } \\
\text { at Birth, } \\
\text { Females }\end{array}$} & \multirow[b]{2}{*}{$\begin{array}{c}\text { Infant } \\
\text { Mortality } \\
\text { Rate, per } \\
\text { 1,000 Live } \\
\text { Births } 1 / \\
\end{array}$} & \multirow[b]{2}{*}{$\begin{array}{c}\text { Prevalence of } \\
\text { Tuber- } \\
\text { culosis, per } \\
100,000 \\
\text { Populat. 1/ } \\
\end{array}$} & \multirow[b]{2}{*}{$\begin{array}{c}\text { Physicians } \\
\text { per } 1,000 \\
\text { Population }\end{array}$} & \multicolumn{4}{|c|}{ Age-standardized mortality rates $1 /$} & \multicolumn{2}{|c|}{ Efficiency Score } \\
\hline & & & & & & & & $\begin{array}{c}\text { Non- } \\
\text { communic- } \\
\text { able Diseases }\end{array}$ & $\begin{array}{l}\text { Cardio- } \\
\text { Vascular } \\
\text { diseases } \\
\end{array}$ & Cancer & Injuries & $\begin{array}{l}\text { Controlling } \\
\text { for Income } \\
\text { per Capita }\end{array}$ & $\begin{array}{c}\text { Not } \\
\text { Controlling } \\
\text { for Income } \\
\text { per Capita } \\
\end{array}$ \\
\hline Argentina & 14,838 & 4.3 & 4.6 & 68.1 & 62.5 & 1,887 & 3.0 & 192 & 471 & 703 & 1,917 & 0.44 & 0.38 \\
\hline Armenia & 4,516 & 1.2 & 4.8 & 62.6 & 34.5 & 1,018 & 3.6 & 125 & 201 & 685 & 2,573 & 0.97 & 0.86 \\
\hline Azerbaijan, Rep. of & 5,895 & 0.9 & 2.7 & 58.7 & 13.3 & 1,116 & 3.5 & 112 & 163 & 887 & 3,423 & 1.00 & 1.00 \\
\hline Belarus & 8,230 & 4.9 & 1.6 & 64.9 & 125.0 & 1,468 & 4.6 & 119 & 169 & 699 & 649 & 1.00 & 0.71 \\
\hline Bosnia \& Herzegovina & 6,456 & 4.8 & 4.7 & 66.4 & 76.9 & 1,872 & 1.3 & 143 & 203 & 828 & 2,342 & 0.59 & 0.36 \\
\hline Botswana & 12,131 & 3.3 & 2.3 & 35.4 & 13.3 & 181 & 0.4 & 153 & 296 & 808 & 1,394 & 0.65 & 0.59 \\
\hline Brazil & 8,917 & 3.4 & 4.2 & 62.4 & 31.3 & 1,303 & 1.2 & 140 & 294 & 705 & 1,241 & 0.57 & 0.45 \\
\hline Bulgaria & 10,003 & 4.1 & 3.4 & 67.1 & 83.3 & 2,767 & 3.6 & 132 & 180 & 800 & 2,369 & 0.64 & 0.47 \\
\hline Chile & 12,737 & 3.0 & 3.1 & 69.7 & 125.0 & 6,325 & 1.1 & 221 & 606 & 732 & 1,987 & 1.00 & 1.00 \\
\hline China,P.R.: Mainland & 8,004 & 2.0 & 3.6 & 65.2 & 38.5 & 452 & 1.1 & 150 & 344 & 675 & 1,270 & 0.68 & 0.62 \\
\hline Colombia & 7,646 & 6.4 & 1.2 & 66.3 & 55.6 & 1,339 & 1.4 & 196 & 417 & 855 & 708 & 1.00 & 0.69 \\
\hline Costa Rica & 10,747 & 5.8 & 1.5 & 69.3 & 90.9 & 6,549 & 1.3 & 219 & 541 & 803 & 1,815 & 1.00 & 0.69 \\
\hline Croatia & 13,062 & 6.5 & 1.3 & 69.3 & 166.7 & 1,538 & 2.4 & 163 & 281 & 598 & 2,083 & 0.91 & 0.66 \\
\hline Czech Republic & 19,428 & 6.8 & 0.8 & 70.9 & 250.0 & 8,902 & 3.5 & 176 & 317 & 566 & 1,996 & 1.00 & 1.00 \\
\hline Dominican Republic & 8,018 & 2.3 & 4.7 & 61.9 & 37.0 & 850 & 1.9 & 145 & 263 & 762 & 1,695 & 0.56 & 0.50 \\
\hline Estonia & 17,802 & 4.1 & 1.2 & 69.0 & 166.7 & 2,034 & 4.5 & 148 & 230 & 667 & 692 & 1.00 & 1.00 \\
\hline Georgia & 3,755 & 1.0 & 3.0 & 66.6 & 24.4 & 1,120 & 4.1 & 134 & 171 & 1,094 & 3,939 & 1.00 & 1.00 \\
\hline Hungary & 17,821 & 6.1 & 2.3 & 68.2 & 142.9 & 3,372 & 3.3 & 144 & 275 & 498 & 1,486 & 0.54 & 0.48 \\
\hline Iran, I.R. of & 8,441 & 3.1 & 3.4 & 59.1 & 31.3 & 2,837 & 0.4 & 135 & 215 & 882 & 752 & 0.70 & 0.55 \\
\hline Kazakhstan & 9,134 & 2.0 & 1.5 & 59.3 & 15.9 & 624 & 3.5 & 95 & 140 & 598 & 627 & 1.00 & 1.00 \\
\hline Kyrgyz Republic & 2,224 & 2.2 & 3.1 & 58.4 & 17.2 & 732 & 2.5 & 108 & 166 & 941 & 1,115 & 1.00 & 0.65 \\
\hline Latvia & 13,875 & 3.3 & 3.1 & 67.5 & 111.1 & 1,399 & 3.0 & 136 & 207 & 640 & 757 & 0.61 & 0.57 \\
\hline Libya & 12,146 & 2.6 & 1.5 & 65.0 & 55.6 & 5,008 & 1.3 & 154 & 243 & 1,270 & 1,833 & 1.00 & 1.00 \\
\hline Lithuania & 15,443 & 5.0 & 1.6 & 67.7 & 125.0 & 1,503 & 4.0 & 156 & 256 & 621 & 736 & 0.73 & 0.68 \\
\hline Malaysia & 11,915 & 2.2 & 1.6 & 64.8 & 100.0 & 754 & 0.7 & 160 & 364 & 721 & 1,989 & 1.00 & 1.00 \\
\hline Mauritius & 13,508 & 2.2 & 1.5 & 64.6 & 83.3 & 738 & 1.1 & 143 & 230 & 1,268 & 2,390 & 1.00 & 1.00 \\
\hline Mexico & 10,604 & 2.9 & 3.3 & 67.6 & 43.5 & 2,312 & 2.0 & 199 & 614 & 1,136 & 1,723 & 0.64 & 0.57 \\
\hline Poland & 13,797 & 4.5 & 2.0 & 68.5 & 142.9 & 3,132 & 2.5 & 169 & 308 & 555 & 1,878 & 0.75 & 0.63 \\
\hline Moldova & 2,708 & 3.9 & 3.3 & 62.4 & 43.5 & 468 & 2.6 & 108 & 162 & 859 & 1,026 & 1.00 & 0.47 \\
\hline Romania & 9,446 & 3.8 & 2.3 & 65.2 & 58.8 & 532 & 1.9 & 137 & 209 & 708 & 1,787 & 0.75 & 0.56 \\
\hline Russia & 11,904 & 3.3 & 3.4 & 64.1 & 76.9 & 624 & 4.3 & 104 & 145 & 657 & 461 & 0.72 & 0.65 \\
\hline Slovak Republic & 17,239 & 5.2 & 0.7 & 69.4 & 142.9 & 4,271 & 3.2 & 157 & 270 & 589 & 1,995 & 1.00 & 1.00 \\
\hline Slovenia & 23,159 & 6.7 & 2.1 & 72.3 & 250.0 & 5,945 & 2.3 & 199 & 439 & 627 & 1,691 & 0.60 & 0.57 \\
\hline South Africa & 12,760 & 3.2 & 5.2 & 45.3 & 18.5 & 149 & 0.8 & 124 & 244 & 649 & 836 & 0.45 & 0.41 \\
\hline Tajikistan & 1,506 & 0.9 & 3.5 & 56.4 & 11.0 & 361 & 2.0 & 97 & 133 & 1,111 & 1,570 & 1.00 & 0.94 \\
\hline Thailand & 8,877 & 2.0 & 1.3 & 62.4 & 55.6 & 481 & 0.4 & 179 & 502 & 774 & 1,358 & 1.00 & 1.00 \\
\hline Serbia and Montenegro & 5,713 & 7.2 & 2.4 & 64.9 & 76.9 & 2,007 & 2.1 & 130 & 197 & 673 & 2,777 & 1.00 & 0.45 \\
\hline Macedonia & 8,175 & 6.0 & 1.1 & 65.0 & 76.9 & 2,972 & 2.2 & 134 & 198 & 691 & 1,359 & 1.00 & 0.75 \\
\hline Tunisia & 8,809 & 2.5 & 2.9 & 63.6 & 47.6 & 4,172 & 1.3 & 146 & 240 & 1,277 & 1,394 & 0.98 & 0.71 \\
\hline Turkey & 8,385 & 5.4 & 2.2 & 62.8 & 35.7 & 2,231 & 1.3 & 132 & 184 & 1,057 & 2,368 & 0.79 & 0.52 \\
\hline Turkmenistan & 8,663 & 2.6 & 1.3 & 57.2 & 12.5 & 1,210 & 4.2 & 90 & 118 & 1,007 & 1,348 & 1.00 & 1.00 \\
\hline Ukraine & 7,816 & 3.8 & 1.9 & 63.6 & 71.4 & 663 & 3.0 & 112 & 157 & 718 & 743 & 0.90 & 0.64 \\
\hline Uruguay & 11,378 & 2.7 & 7.1 & 69.4 & 83.3 & 3,051 & 3.7 & 193 & 481 & 587 & 1,811 & 0.44 & 0.44 \\
\hline Uzbekistan & 1,983 & 2.4 & 3.1 & 60.9 & 17.5 & 640 & 2.7 & 111 & 151 & 1,351 & 1,998 & 1.00 & 0.63 \\
\hline
\end{tabular}

Sources: WHO, IMF, WEO, database and Fund staff calculations.

1/ Inverted (following Afonso, Schuknecht, and Tanzi, 2005), because better outcomes have to be reflected in higher values. 
Table 2. General Government-Multiple-Outcome Education Efficiency Model

\begin{tabular}{|c|c|c|c|c|c|c|c|}
\hline \multirow[b]{2}{*}{ Country } & \multirow[b]{2}{*}{$\begin{array}{c}\text { Income per } \\
\text { Capita (U.S. } \\
\text { dollars, PPP) }\end{array}$} & \multirow[b]{2}{*}{$\begin{array}{c}\text { Public } \\
\text { Expenditure } \\
\text { per Student } \\
\text { (Primary- } \\
\text { Tertiary), } \\
\text { Percent of } \\
\text { GDP per } \\
\text { Capita } \\
\end{array}$} & \multirow[b]{2}{*}{$\begin{array}{l}\text { Teacher- } \\
\text { Pupil Ratio } \\
\text { (Primary) } \\
\end{array}$} & \multirow[b]{2}{*}{$\begin{array}{c}\text { Teacher- } \\
\text { Pupil Ratio } \\
\text { (Secondary) } \\
\end{array}$} & \multirow[b]{2}{*}{$\begin{array}{c}\text { Tertiary } \\
\text { Graduates in } \\
\text { Percent of } \\
\text { Tertiary } \\
\text { School-Age } \\
\text { Population } \\
\end{array}$} & \multicolumn{2}{|c|}{ Efficiency Score } \\
\hline & & & & & & $\begin{array}{l}\text { Controlling } \\
\text { for Income } \\
\text { per Capita } \\
\end{array}$ & \begin{tabular}{l}
\multicolumn{1}{c}{ Not } \\
Controlling \\
for Income \\
per Capita \\
\end{tabular} \\
\hline Belarus & 8,230 & 22.2 & 0.06 & 0.11 & 11.8 & 1.00 & 1.00 \\
\hline Belize & 8,055 & 15.2 & 0.04 & 0.05 & 0.5 & 1.00 & 0.52 \\
\hline Botswana & 12,131 & 7.3 & 0.04 & 0.07 & 0.6 & 1.00 & 1.00 \\
\hline Brazil & 8,917 & 13.7 & 0.05 & 0.06 & 3.1 & 0.95 & 0.63 \\
\hline Bulgaria & 10,003 & 21.8 & 0.06 & 0.08 & 8.4 & 0.85 & 0.62 \\
\hline Chile & 12,737 & 13.9 & 0.04 & 0.04 & 7.9 & 0.85 & 0.82 \\
\hline Colombia & 7,646 & 17.5 & 0.04 & 0.04 & 2.0 & 1.00 & 0.46 \\
\hline Costa Rica & 10,747 & 19.2 & 0.04 & 0.05 & 6.2 & 0.76 & 0.54 \\
\hline Croatia & 13,062 & 25.8 & 0.06 & 0.09 & 5.1 & 0.68 & 0.51 \\
\hline Czech Republic & 19,428 & 21.9 & 0.06 & 0.08 & 7.8 & 0.58 & 0.55 \\
\hline Estonia & 17,802 & 24.1 & 0.07 & 0.10 & 9.9 & 0.78 & 0.78 \\
\hline Hungary & 17,821 & 26.8 & 0.10 & 0.10 & 10.2 & 1.00 & 1.00 \\
\hline Iran, I.R. of & 8,441 & 12.5 & 0.05 & 0.05 & 3.2 & 1.00 & 0.73 \\
\hline Latvia & 13,875 & 21.5 & 0.08 & 0.09 & 13.6 & 1.00 & 1.00 \\
\hline Lithuania & 15,443 & 19.1 & 0.07 & 0.09 & 14.8 & 1.00 & 1.00 \\
\hline Macedonia, FYR & 8,175 & 14.2 & 0.05 & 0.07 & 3.1 & 1.00 & 0.65 \\
\hline Malaysia & 11,915 & 30.4 & 0.06 & 0.06 & 8.6 & 0.67 & 0.42 \\
\hline Mauritius & 13,508 & 18.2 & 0.04 & 0.06 & 4.2 & 0.67 & 0.51 \\
\hline Mexico & 10,604 & 18.9 & 0.04 & 0.06 & 3.5 & 0.77 & 0.47 \\
\hline Poland & 13,797 & 22.6 & 0.08 & 0.07 & 14.6 & 1.00 & 1.00 \\
\hline Romania & 9,446 & 15.5 & 0.06 & 0.07 & 8.9 & 1.00 & 0.83 \\
\hline Russia & 11,904 & 14.6 & 0.06 & 0.10 & 13.4 & 1.00 & 1.00 \\
\hline Slovak Republic & 17,239 & 18.4 & 0.06 & 0.08 & 7.9 & 0.69 & 0.67 \\
\hline Slovenia & 23,159 & 26.8 & 0.07 & 0.09 & 10.8 & 0.61 & 0.61 \\
\hline South Africa & 12,760 & 17.8 & 0.03 & 0.03 & 2.3 & 0.68 & 0.46 \\
\hline Thailand & 8,877 & 15.0 & 0.05 & 0.04 & 8.8 & 0.96 & 0.80 \\
\hline Tunisia & 8,809 & 29.8 & 0.05 & 0.06 & 2.8 & 0.88 & 0.29 \\
\hline Ukraine & 7,816 & 17.8 & 0.05 & 0.08 & 15.4 & 1.00 & 1.00 \\
\hline Uruguay & 11,378 & 8.4 & 0.05 & 0.07 & 2.7 & 1.00 & 1.00 \\
\hline
\end{tabular}

Sources: USESCO; IMF, WEO database and Fund staff calculations. 
Table 3. General Government—-Social Protection Efficiency Model

\begin{tabular}{|c|c|c|c|c|c|}
\hline \multirow[b]{2}{*}{ Country } & \multirow[b]{2}{*}{$\begin{array}{c}\text { Per Capita } \\
\text { Income (U.S. } \\
\text { Dollars, PPP) }\end{array}$} & \multirow[b]{2}{*}{$\begin{array}{c}\text { Social } \\
\text { Protection } \\
\text { Spending in } \\
\text { Percent of } \\
\text { GDP } \\
\end{array}$} & \multirow[b]{2}{*}{$\begin{array}{c}\text { Gini } \\
\text { Coefficient 1/ }\end{array}$} & \multicolumn{2}{|c|}{ Efficiency Score } \\
\hline & & & & $\begin{array}{l}\text { Controlling } \\
\text { for Income } \\
\text { per Capita }\end{array}$ & \begin{tabular}{c}
\multicolumn{1}{c}{ Not } \\
Controlling \\
for Income \\
per Capita \\
\end{tabular} \\
\hline Austria & 34,803 & 20.3 & 0.034 & 0.51 & 0.50 \\
\hline Bolivia & 2,791 & 5.3 & 0.017 & 1.00 & 0.44 \\
\hline Hong Kong SAR & 35,396 & 2.5 & 0.022 & 1.00 & 1.00 \\
\hline Czech Republic & 19,428 & 12.3 & 0.025 & 0.47 & 0.36 \\
\hline El Salvador & 4,620 & 2.4 & 0.019 & 1.00 & 1.00 \\
\hline Finland & 32,822 & 19.6 & 0.037 & 0.62 & 0.62 \\
\hline Hungary & 17,821 & 12.1 & 0.037 & 1.00 & 1.00 \\
\hline Israel & 24,357 & 12.2 & 0.026 & 0.47 & 0.37 \\
\hline Italy & 29,406 & 16.7 & 0.028 & 0.42 & 0.36 \\
\hline Lithuania & 15,443 & 9.1 & 0.028 & 0.77 & 0.66 \\
\hline Luxembourg & 72,855 & 22.4 & 0.033 & 0.40 & 0.40 \\
\hline Norway & 44,342 & 16.0 & 0.039 & 1.00 & 1.00 \\
\hline Poland & 13,797 & 18.2 & 0.029 & 0.86 & 0.37 \\
\hline Russia & 11,904 & 9.1 & 0.025 & 0.75 & 0.46 \\
\hline Slovak Republic & 17,239 & 12.7 & 0.026 & 0.55 & 0.37 \\
\hline South Africa & 12,760 & 3.2 & 0.017 & 0.73 & 0.73 \\
\hline Spain & 27,542 & 11.9 & 0.029 & 0.62 & 0.56 \\
\hline Sweden & 31,264 & 22.4 & 0.040 & 1.00 & 1.00 \\
\hline United States & 43,236 & 6.8 & 0.025 & 0.62 & 0.57 \\
\hline
\end{tabular}

Sources: IMF, Government Finance Statistics, WEO database, and Fund staff calculations, and World Bank, World Development Indicators.

1/ Inverted (following Afonso, Schuknecht, and Tanzi, 2005), because better outcomes have to be reflected in higher values. 
Table 4. Local Governments-Data Description

\begin{tabular}{|c|c|c|c|}
\hline Acronym & Definition & Mean & StDv \\
\hline \multicolumn{4}{|c|}{ Outcome indicators: } \\
\hline HOSPITAL & Number of hospital beds per 10,000 people, end-year, 2004. & 121 & 25.6 \\
\hline PHYSICIAN & Number of physicians per 10,000 people, end-year, 2004. & 46.4 & 11.1 \\
\hline INFANT & Infant mortality rate (number of deaths within first year of life per 1,000,000 born alive), 2002-03 average. & 12,802 & 3,402 \\
\hline LIFE & $\begin{array}{l}\text { Life expectancy at birth in years. Females only, because their life expectancy tends to be somewhat less affected by alcoholism that } \\
\text { has been identified as a key driver in the increase in mortality in Russia in the 1990s (DaVanzo and Grammich, 2001). 2004. }\end{array}$ & 71.5 & 2.7 \\
\hline PRESCHOOL & Pre-schooling coverage of children in \% of children of applicable age, end-year, 2004. & 59.5 & 13.0 \\
\hline PROFEDU & $\begin{array}{l}\text { Professional education coverage. Students in primary and secondary professional education in \% of below-working-age population, } \\
\text { end-year, } 2004 .\end{array}$ & 17.5 & 4.1 \\
\hline GENTEACH & Teacher-student ratio in general education. Teachers per student in general education schools, beginning of school year, 2003. & 0.08 & 0.01 \\
\hline PROFTEACH & $\begin{array}{l}\text { Teacher-student ratio in professional education. Teachers per student in primary and secondary public professional education } \\
\text { schools, beginning of school year, } 2003 .\end{array}$ & 0.06 & 0.02 \\
\hline POVERTY & $\begin{array}{l}\text { Percentage of population with per capita income below } 3,000 \text { rubles monthly, estimated by adjusting the income brackets by } \\
\text { regional price level, } 2004 \text {. }\end{array}$ & 41.4 & 14.1 \\
\hline INEQUALITY & Gini coefficient, 2003. & 0.36 & 0.04 \\
\hline \multicolumn{4}{|c|}{ Public expenditure: } \\
\hline EXPHEL & Public health expenditure. Consolidated regional government expenditure on health in \% of gross regional product, 2004. & 3.3 & 2.0 \\
\hline EXPEDU & Public education expenditure. Consolidated regional government expenditure on education in \% of gross regional product, 2004. & 4.9 & 2.6 \\
\hline EXPSOC & $\begin{array}{l}\text { Public social protection expenditure. Consolidated regional government expenditure on social policy in \% of gross regional product, } \\
2004 \text {. }\end{array}$ & 2.0 & 1.2 \\
\hline EXPTOT & =EXPHEL+EXPEDU+EXPSOC & 10.1 & 5.4 \\
\hline \multicolumn{4}{|c|}{ Other potential correlates: } \\
\hline INCPERCAP & $\begin{array}{l}\text { Income per capita. Gross regional product per capita in rubles, adjusted by dividing by the ratio of the regional to national price } \\
\text { level, } 2003 \text {. }\end{array}$ & 65,245 & 36,932 \\
\hline FUEL & Fuel sector in \% of total industrial production, 2003-04 average. & 11.0 & 17.7 \\
\hline ALCTOB & Percentage of alcohol and tobacco in household consumption, 2004. & 3.1 & 0.8 \\
\hline OLD & Percentage of population older than working age, end-year, 2004. & 19.4 & 4.5 \\
\hline DENSITY & Population per square kilometer, end-year, 2004. & 36.6 & 57.8 \\
\hline TEMPJAN & Average temperature in January in degrees Celsius. & -10.5 & 7.7 \\
\hline MOSCOW & Distance of main regional city from Moscow in kilometers. & 2,367 & 2,748 \\
\hline POPULATION & Population in thousands, end-year, 2004. & 1,802 & 1,622 \\
\hline TRANSFERS & Percentage of federal transfers in government revenue, 2000-04 average. & 27.7 & 20.5 \\
\hline RISK & Investment risk index, 2006. Scores from 1 (lowest risk) to 4 (highest risk). Source: http://www.raexpert.ru/ratings/regions/2006/. & 2.2 & 1.1 \\
\hline SHADOW & Importance of the shadow economy. Percentage of "other income" in household cash income, 2004. & 21.1 & 8.3 \\
\hline ACADEMIC & Percentage of employed population with higher professional education degree, 2004. & 24.0 & 5.3 \\
\hline URBAN & Percentage of urban population, end-year, 2004. & 68.9 & 12.7 \\
\hline PRIVHEL & Household consumption in health in \% of gross regional product, 2004. & 1.6 & 0.7 \\
\hline PRIVEDU & Household consumption in education in \% of gross regional product, 2004. & 1.2 & 0.6 \\
\hline
\end{tabular}


Table 5. Local Governments—Summary of Performance and Efficiency Scores

\begin{tabular}{|c|c|c|c|c|c|c|c|c|c|c|c|c|}
\hline & \multicolumn{3}{|c|}{ Health } & \multicolumn{3}{|c|}{ Education } & \multicolumn{3}{|c|}{ Social Protection } & \multicolumn{3}{|c|}{ Social Sectors } \\
\hline & PSP & PSE & DEA & PSP & PSE & DEA & PSP & PSE & DEA & PSP & PSE & DEA 2/ \\
\hline Mean 1/ & 1.00 & 0.37 & 0.62 & 1.00 & 0.25 & 0.68 & 1.00 & 0.61 & 0.61 & 1.00 & 1.22 & 0.64 \\
\hline Coefficient of variation & 0.10 & 0.42 & 0.37 & 0.11 & 0.40 & 0.39 & 0.17 & 0.42 & 0.35 & 0.10 & 0.38 & 0.31 \\
\hline Minimum & 0.60 & 0.04 & 0.21 & 0.64 & 0.05 & 0.14 & 0.72 & 0.08 & 0.12 & 0.74 & 0.19 & 0.19 \\
\hline 1st quartile & 1.00 & 0.37 & 0.62 & 1.00 & 0.25 & 0.68 & 1.00 & 0.61 & 0.61 & 1.00 & 1.22 & 0.64 \\
\hline Median 1/ & 0.99 & 0.35 & 0.58 & 1.02 & 0.24 & 0.67 & 0.98 & 0.60 & 0.60 & 1.00 & 1.20 & 0.66 \\
\hline 3rd quartile & 1.00 & 0.37 & 0.62 & 1.00 & 0.25 & 0.68 & 1.00 & 0.61 & 0.61 & 1.00 & 1.22 & 0.64 \\
\hline Maximum & 1.30 & 1.09 & 1.00 & 1.24 & 0.67 & 1.00 & 1.65 & 1.46 & 1.00 & 1.33 & 2.61 & 0.95 \\
\hline \multicolumn{13}{|c|}{ Spearman rank order correlation test: } \\
\hline \multicolumn{13}{|c|}{ Health } \\
\hline PSP & & $0.36 * * *$ & $0.58 * * *$ & $0.50 * * *$ & $0.35 * * *$ & $0.52 * * *$ & $0.27 * * *$ & $0.31 * * *$ & $0.28 * * *$ & $0.71 * * *$ & $0.36^{* * *}$ & $0.59 * * *$ \\
\hline PSE & $0.36 * * *$ & & $0.54 * * *$ & $0.41 * * *$ & $0.88 * * *$ & $0.70 * * *$ & $0.48 * * *$ & $0.73 * * *$ & $0.70 * * *$ & $0.53 * * *$ & $0.90 * * *$ & $0.78 * * *$ \\
\hline DEA & $0.58 * * *$ & $0.54 * * *$ & & $0.52 * * *$ & $0.49 * * *$ & $0.61 * * *$ & $0.32 * * *$ & $0.42 * * *$ & $0.39 * * *$ & $0.62 * * *$ & $0.5 * * *$ & $0.80 * * *$ \\
\hline \multicolumn{13}{|l|}{ Education } \\
\hline PSP & $0.50 * * *$ & $0.41 * * *$ & $0.52 * * *$ & & $0.49 * * *$ & $0.69 * * *$ & $0.21 *$ & $0.38 * * *$ & $0.46^{* * *}$ & $0.66 * * *$ & $0.42 * * *$ & $0.69 * * *$ \\
\hline PSE & $0.35 * * *$ & $0.88 * * *$ & $0.49 * * *$ & $0.49 * * *$ & & $0.77 * * *$ & $0.4 * * *$ & $0.72 * * *$ & $0.73 * * *$ & $0.52 * * *$ & $0.89 * * *$ & $0.80^{* * *}$ \\
\hline DEA & $0.52 * * *$ & $0.70 * * *$ & $0.61 * * *$ & $0.69 * * *$ & $0.77 * * *$ & & $0.34 * * *$ & $0.55^{* * *}$ & $0.56 * * *$ & $0.64 * * *$ & $0.69 * * *$ & $0.89 * * *$ \\
\hline \multicolumn{13}{|l|}{ Social Protection } \\
\hline PSP & $0.27 * * *$ & $0.48 * * *$ & $0.32 * * *$ & $0.21 *$ & $0.40 * * *$ & $0.34 * * *$ & & $0.74 * * *$ & $0.56 * * *$ & $0.77 * * *$ & $0.64 * * *$ & $0.47 * * *$ \\
\hline PSE & $0.31 * * *$ & $0.73 * * *$ & $0.42 * * *$ & $0.38 * * *$ & $0.72 * * *$ & $0.55 * * *$ & $0.74 * * *$ & & $0.92 * * *$ & $0.68 * * *$ & $0.93 * * *$ & $0.73 * * *$ \\
\hline DEA & $0.28 * * *$ & $0.70 * * *$ & $0.39 * * *$ & $0.46^{* * *}$ & $0.73 * * *$ & $0.56 * * *$ & $0.56 * * *$ & $0.92 * * *$ & & $0.58 * * *$ & $0.88 * * *$ & $0.75 * * *$ \\
\hline \multicolumn{13}{|l|}{ Social Sectors } \\
\hline PSP & $0.71 * * *$ & $0.53 * * *$ & $0.62 * * *$ & $0.66^{* * *}$ & $0.52 * * *$ & $0.64 * * *$ & $0.77 * * *$ & $0.68 * * *$ & $0.58 * * *$ & & $0.65 * * *$ & $0.75 * * *$ \\
\hline PSE & $0.36^{* * *}$ & $0.90 * * *$ & $0.50 * * *$ & $0.42 * * *$ & $0.89 * * *$ & $0.69 * * *$ & $0.64 * * *$ & $0.93 * * *$ & $0.88 * * *$ & $0.65 * * *$ & & $0.82 * * *$ \\
\hline DEA & $0.59 * * *$ & $0.78 * * *$ & $0.80 * * *$ & $0.69 * * *$ & $0.80 * * *$ & $0.89 * * *$ & $0.47 * * *$ & $0.73 * * *$ & $0.75 * * *$ & $0.75 * * *$ & $0.82 * * *$ & \\
\hline
\end{tabular}

Source: Fund staff calculations.

Notes: $\mathrm{N}=79 . * * * * * / *$ indicates significance at the 1 percent $/ 5$ percent $/ 10$ percent levels, respectively.

1/ The means of the PSP indicators have been set to unity.

2/ As DEA suffers from an increasing upward bias as additional outputs are added, the overall score was calculated as the simple average of the three subscores.

This also explains why the maximum value is lower than unity, while the maximum must be equal to unity by definition if scores are actually calculated by DEA.. 
Figure 1. Income Level and General Government Spending

(Selected transition economies; latest available observation)
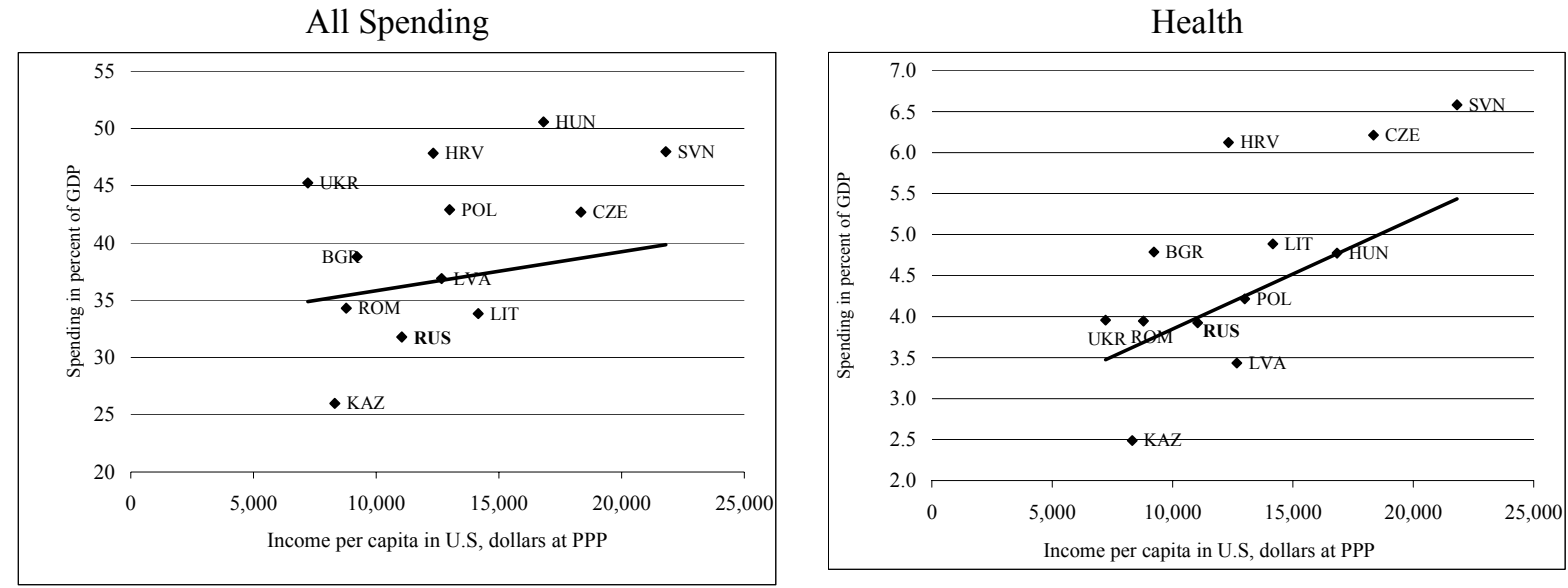

Education

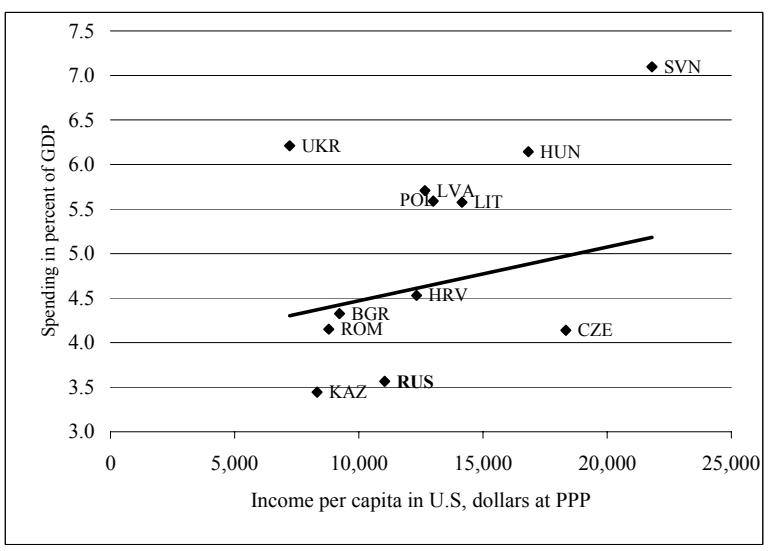

Social Protection

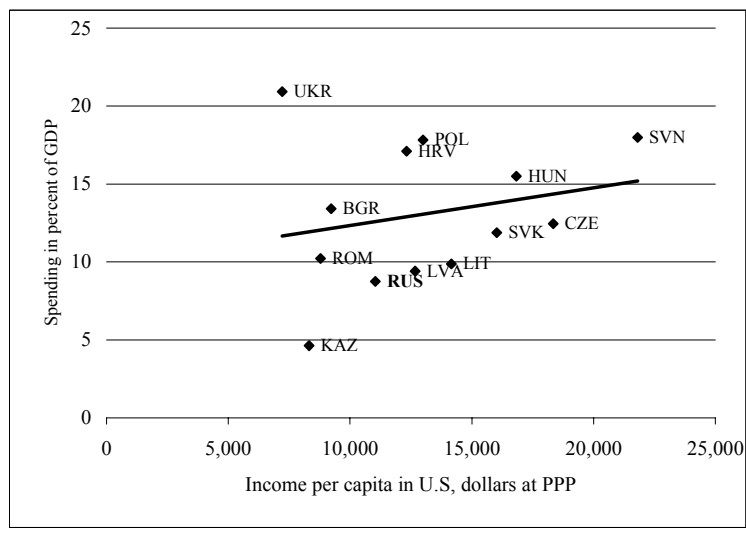

Sources: IMF Government Finance Statistics, WEO database, and Fund staff calculations. 
Figure 2. Structure of General Government Spending-Functional Classification

(Selected transition economies; latest available observation)
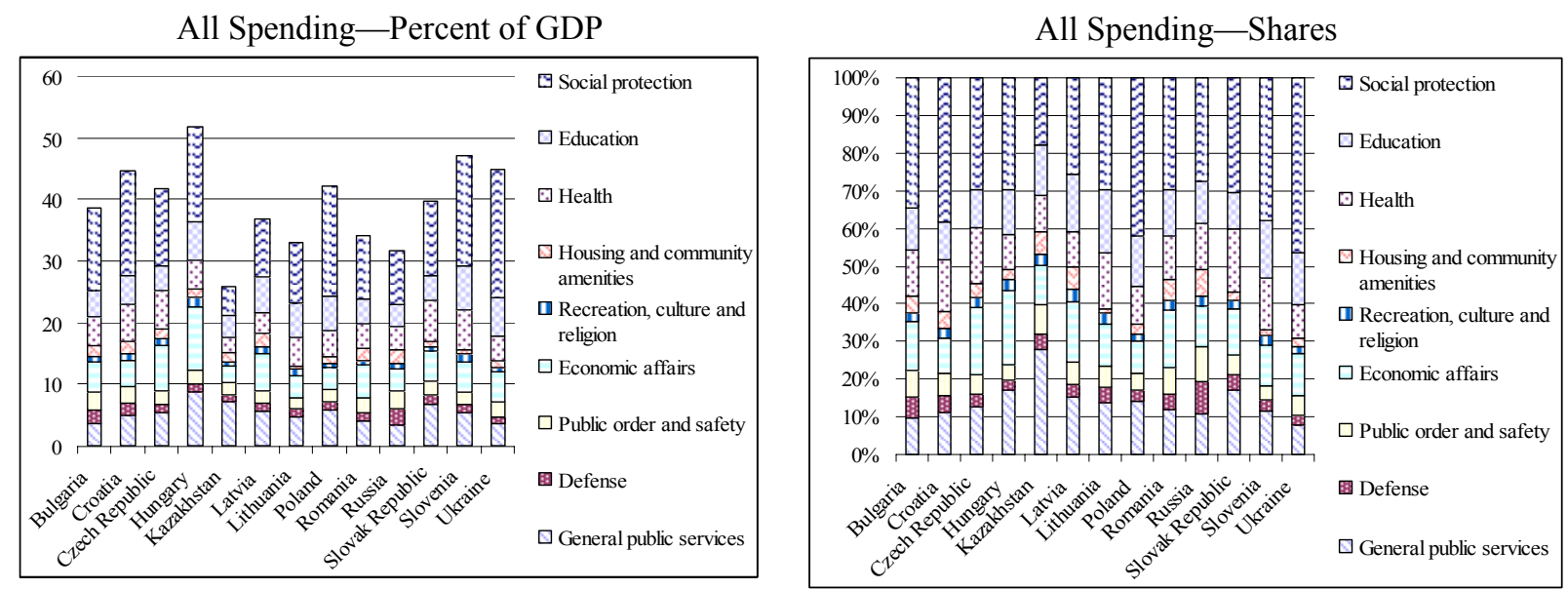

Sources: IMF Government Finance Statistics, WEO database, and Fund staff calculations

Figure 3. Structure of General Government Spending-Economic Classification (Selected transition economies; latest available observation)
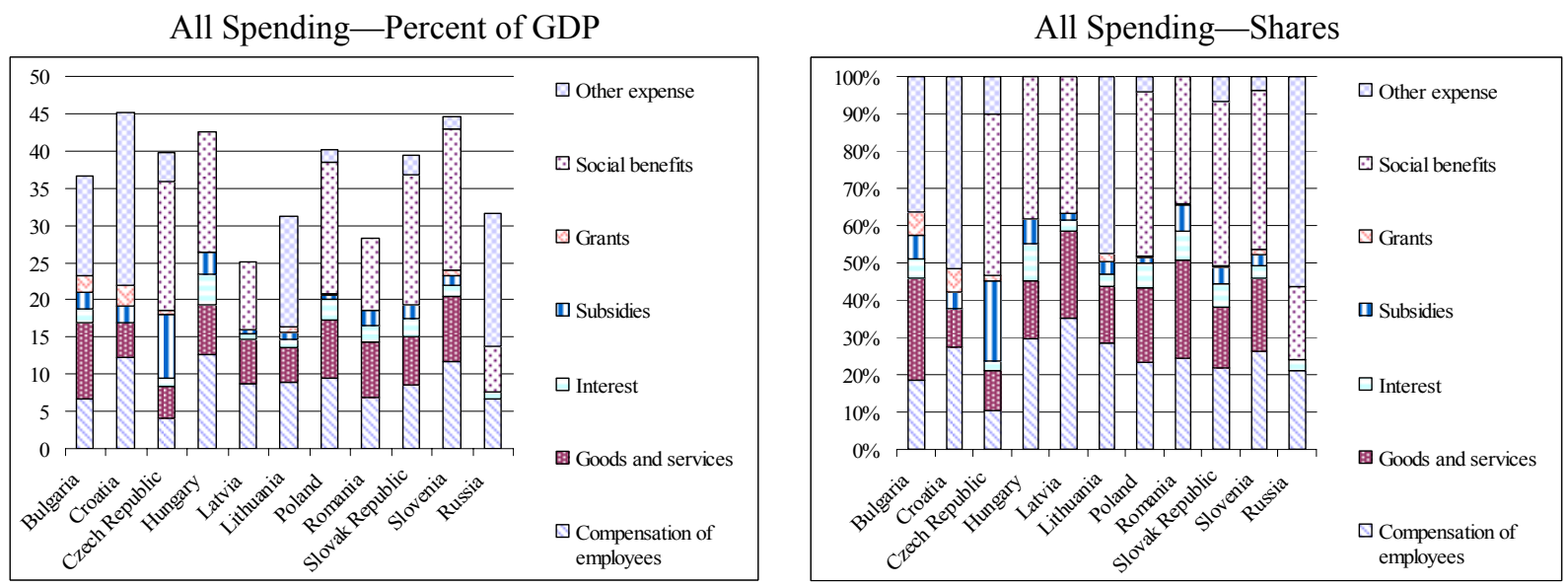

Sources: IMF Government Finance Statistics, WEO database, and Fund staff calculations. 
Figure 4. General Government-Efficiency of Private and Public Health Spending (I)

Healthy Life Expectancy at Birth

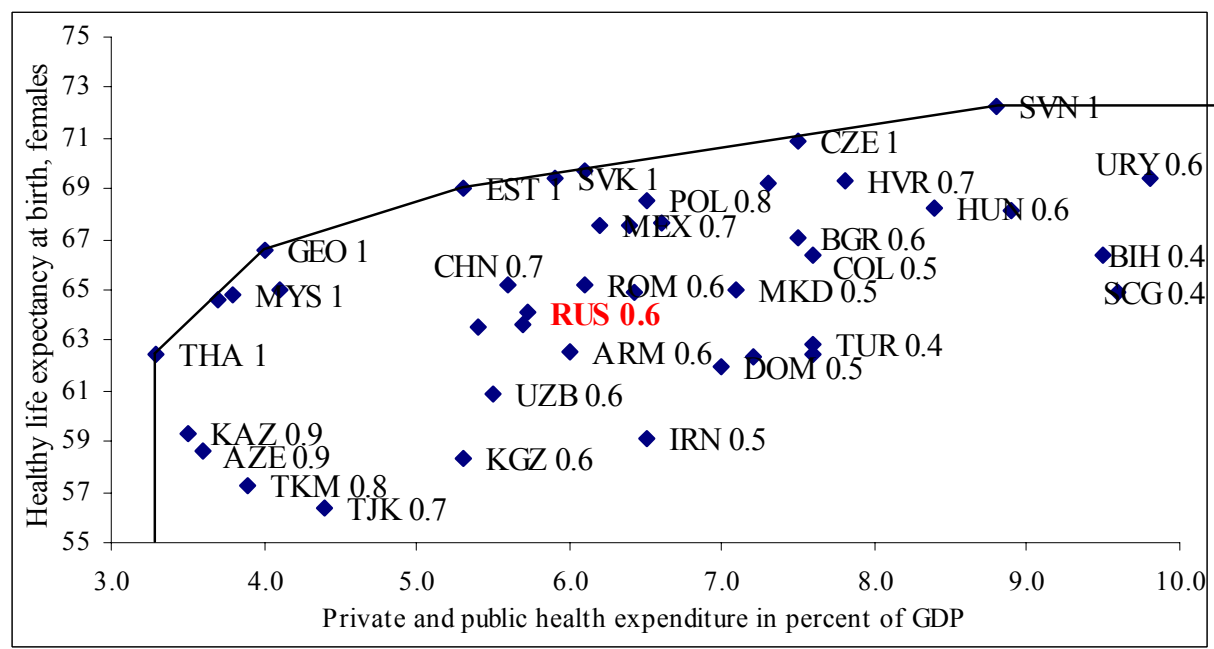

Prevalence of Tuberculosis, per 100,000 Population 1/

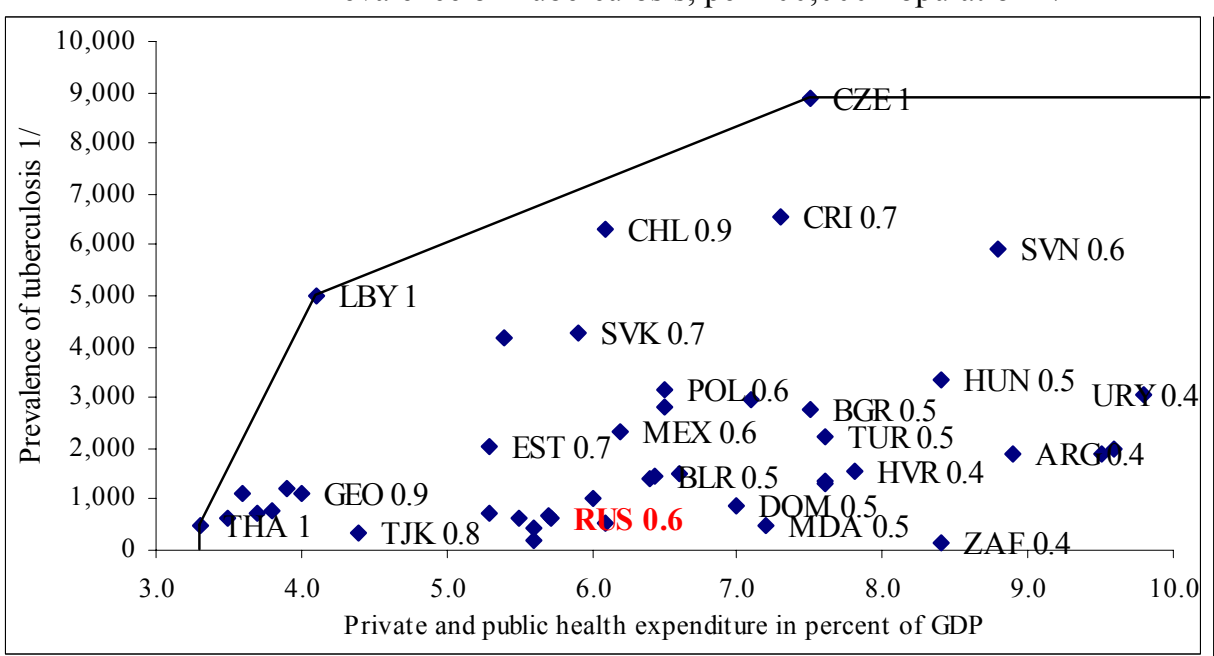

Sources: WHO, IMF, WEO database, and Fund staff calculations.

1/ Inverted (following Afonso, Schuknecht, and Tanzi 2005), because better outcomes have to be reflected in higher values.

Infant Mortality Rate, per 1,000 Live Births 1/

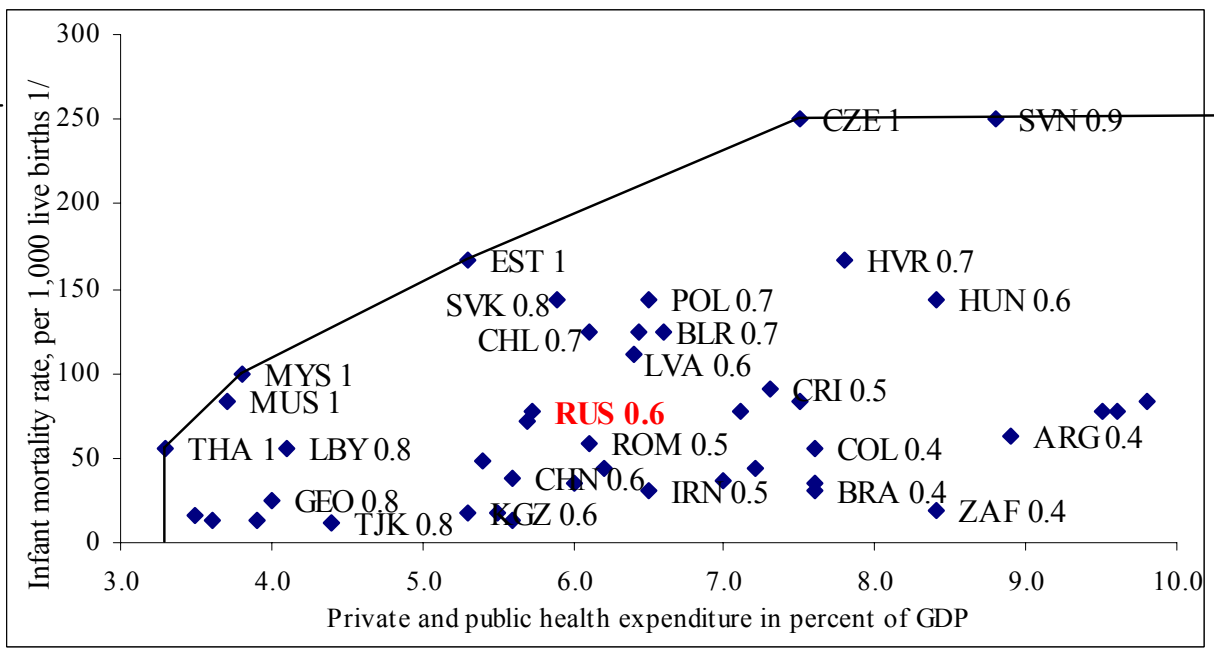

Physicians per 1,000 Population

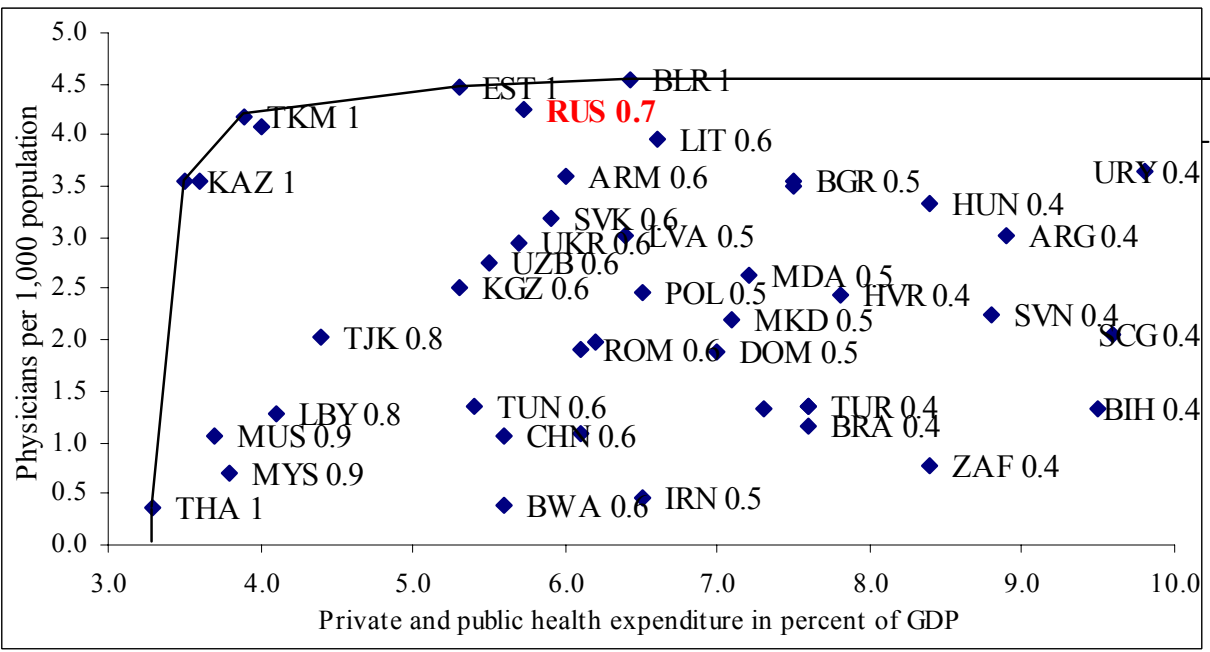


Figure 5. General Government—Efficiency of Private and Public Health Spending (II)

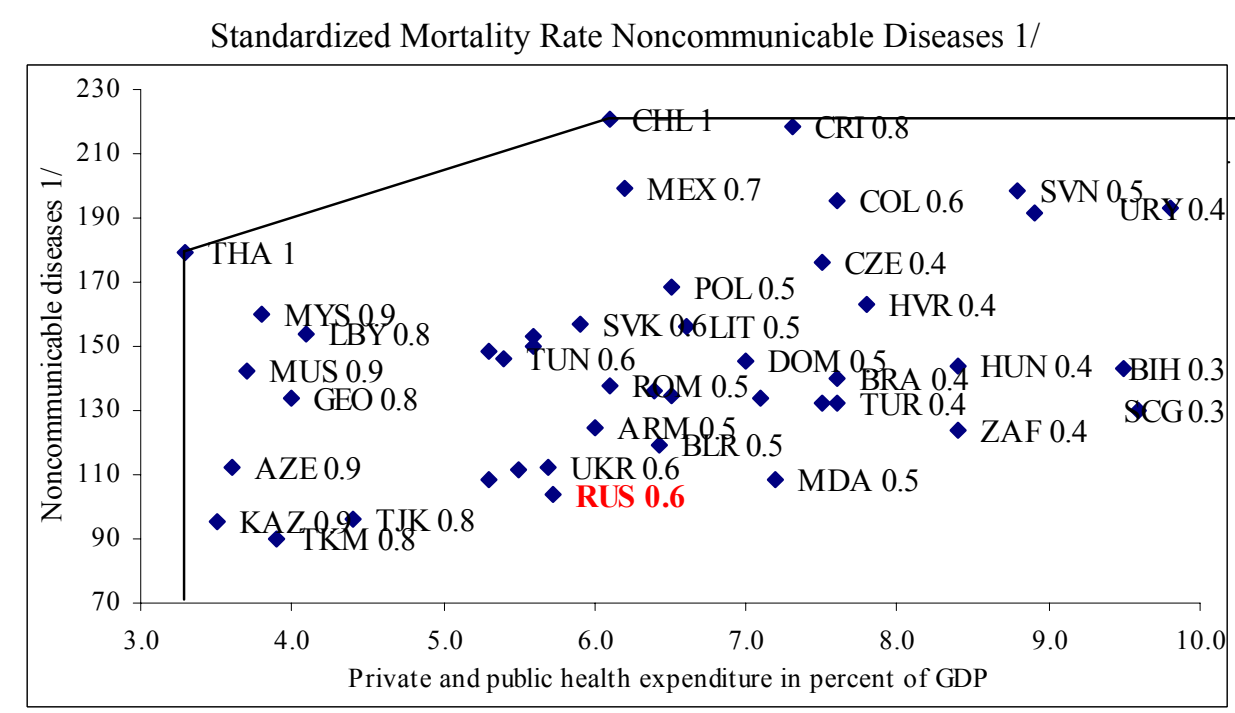

Standardized Mortality Rate-Cardio Vascular Diseases 1/
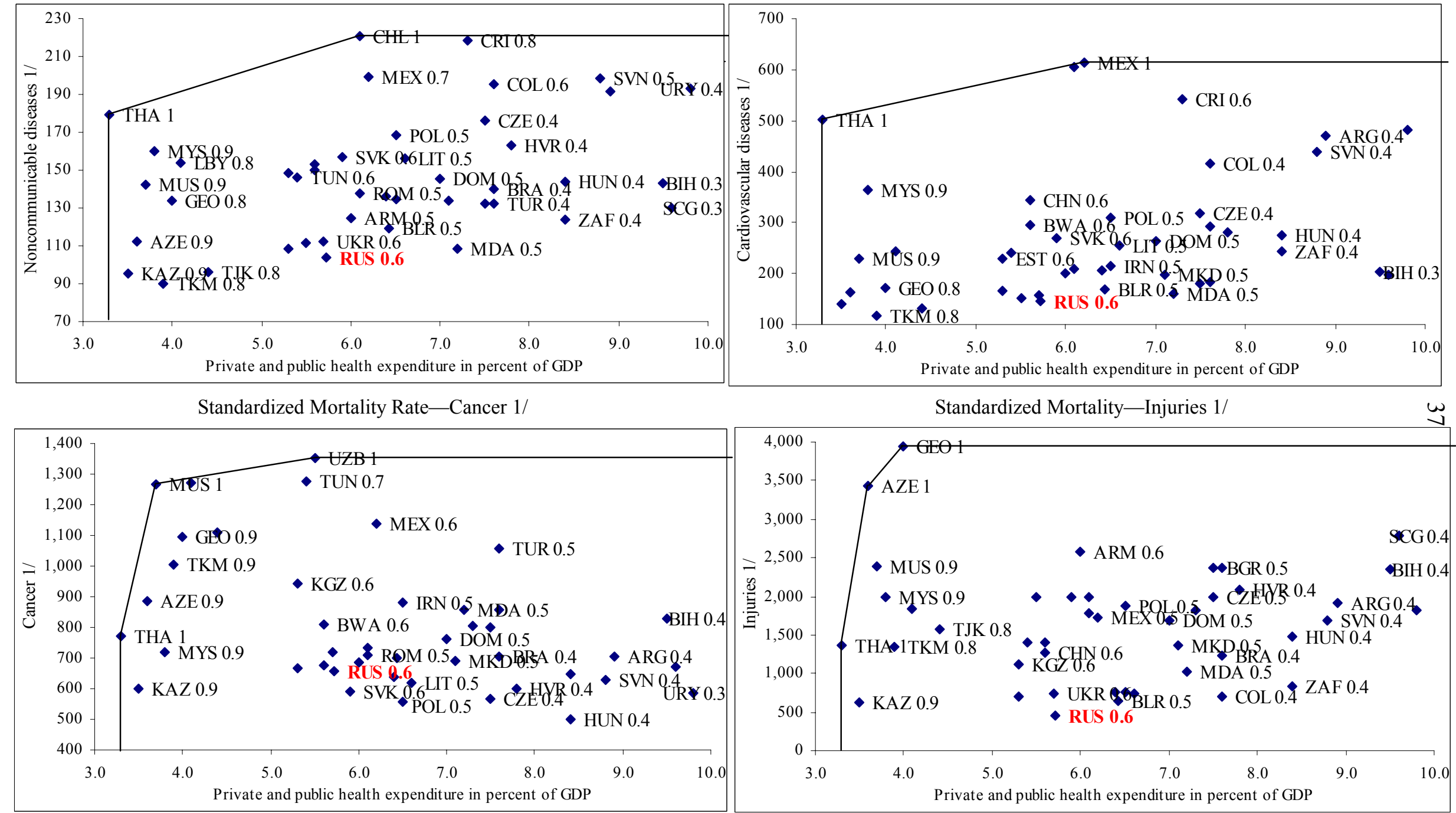

Standardized Mortality—Injuries 1/ w

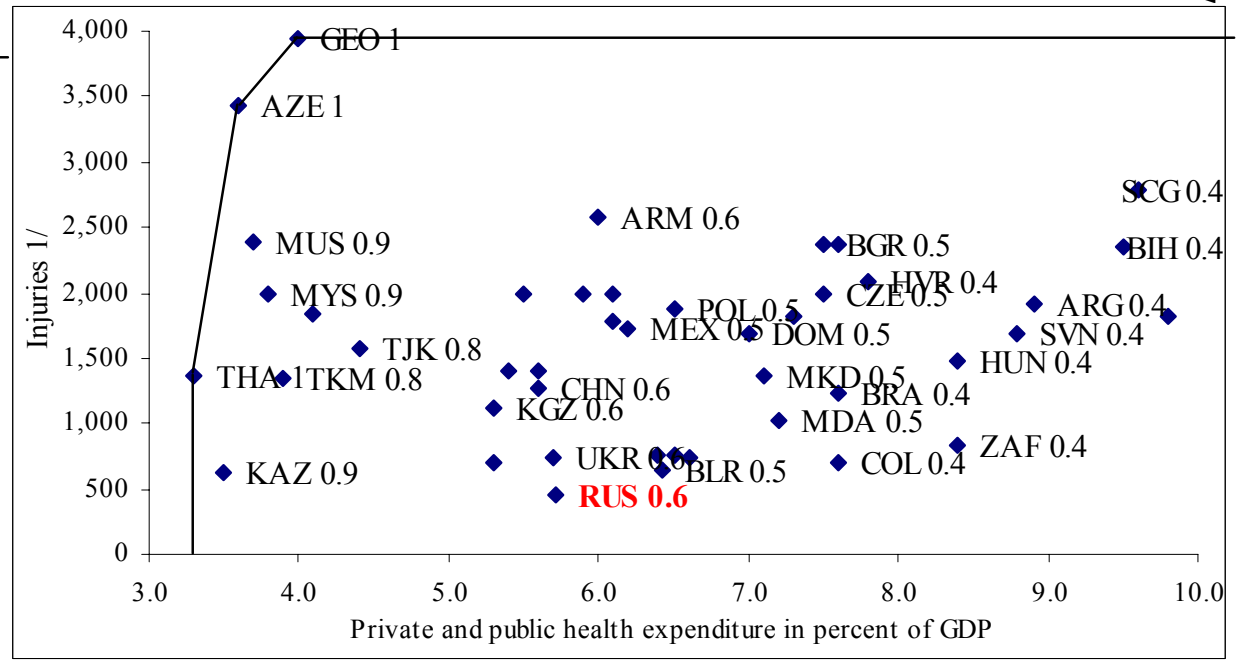

Sources: WHO, IMF, WEO database, and Fund staff calculations.

1/ Inverted (following Afonso, Schuknecht, and Tanzi 2005), because better outcomes have to be reflected in higher values. 
Figure 6. General Government_-Efficiency of Public Education Spending

Primary Education

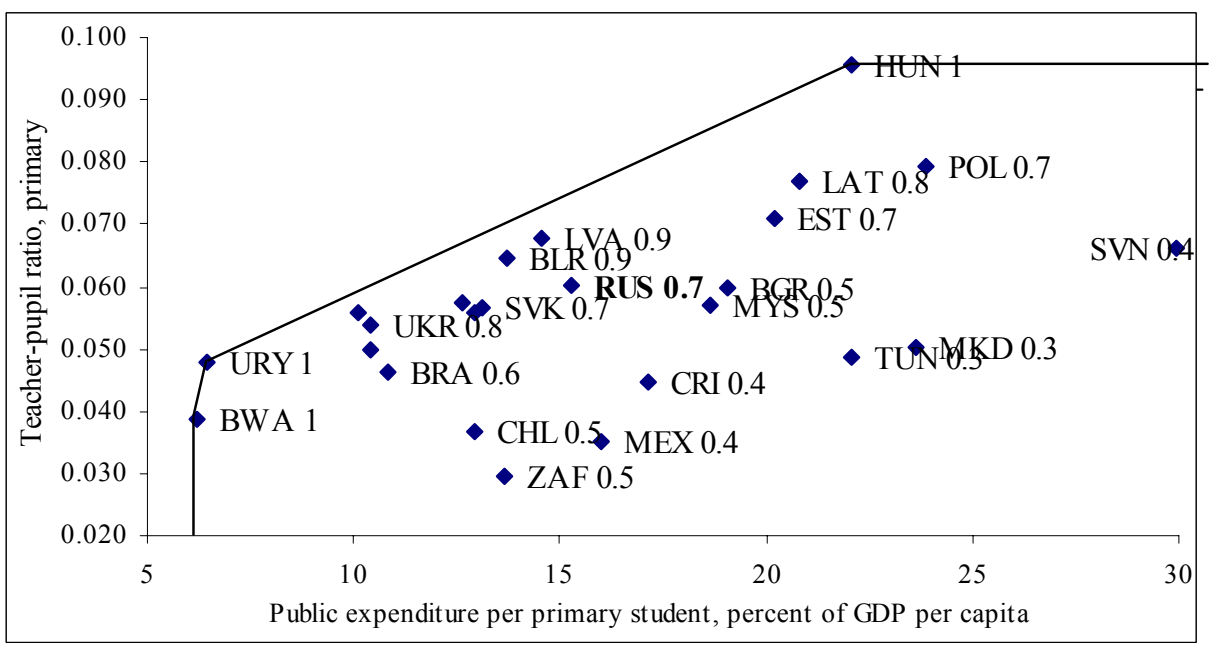

Tertiary Education

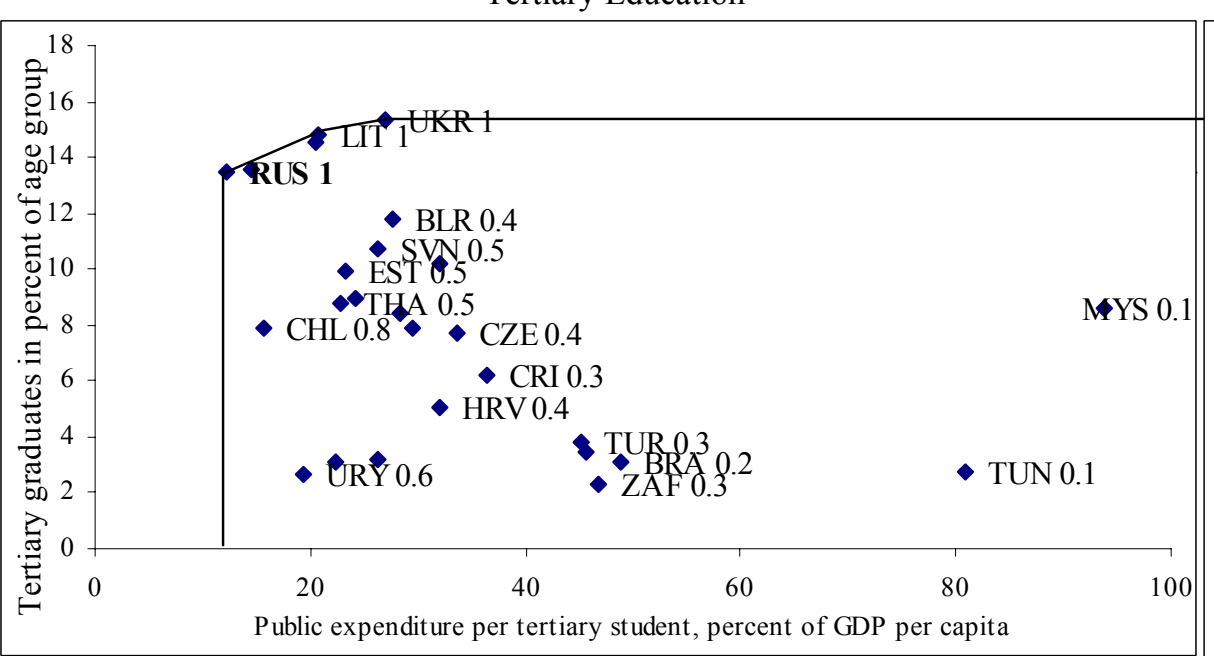

Sources: UNESCO; IMF, WEO database, and Fund staff calculations.
Secondary Education

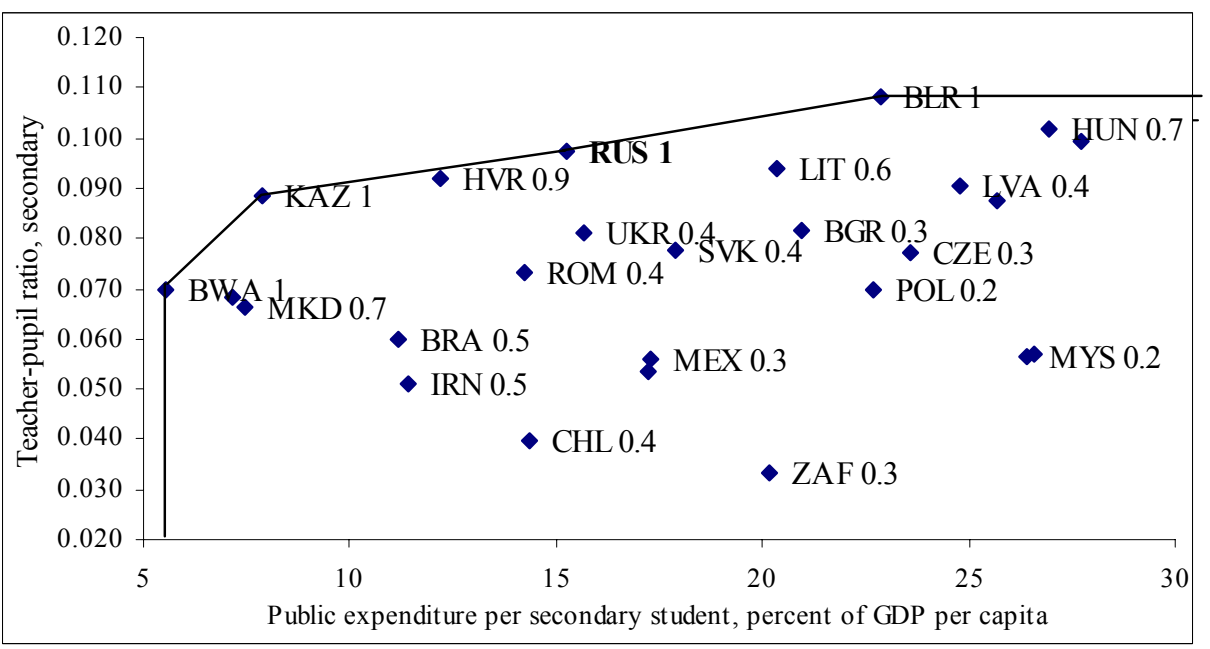

Test Scores

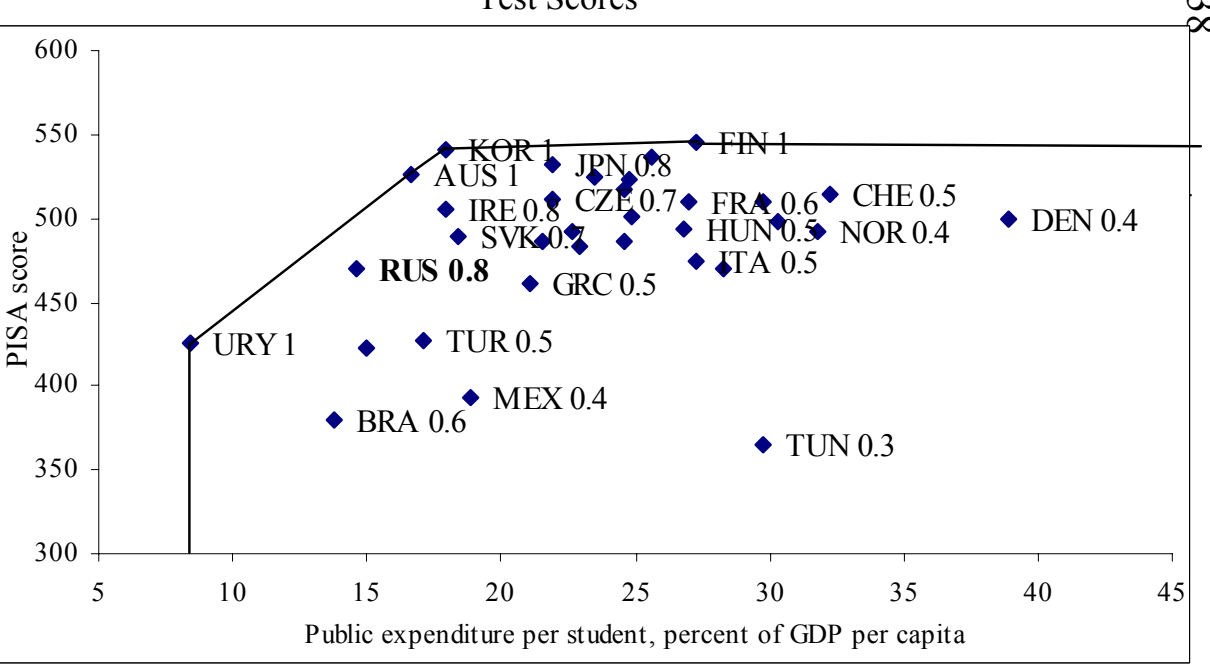


Figure 7. General Government-Efficiency of Social Protection Spending

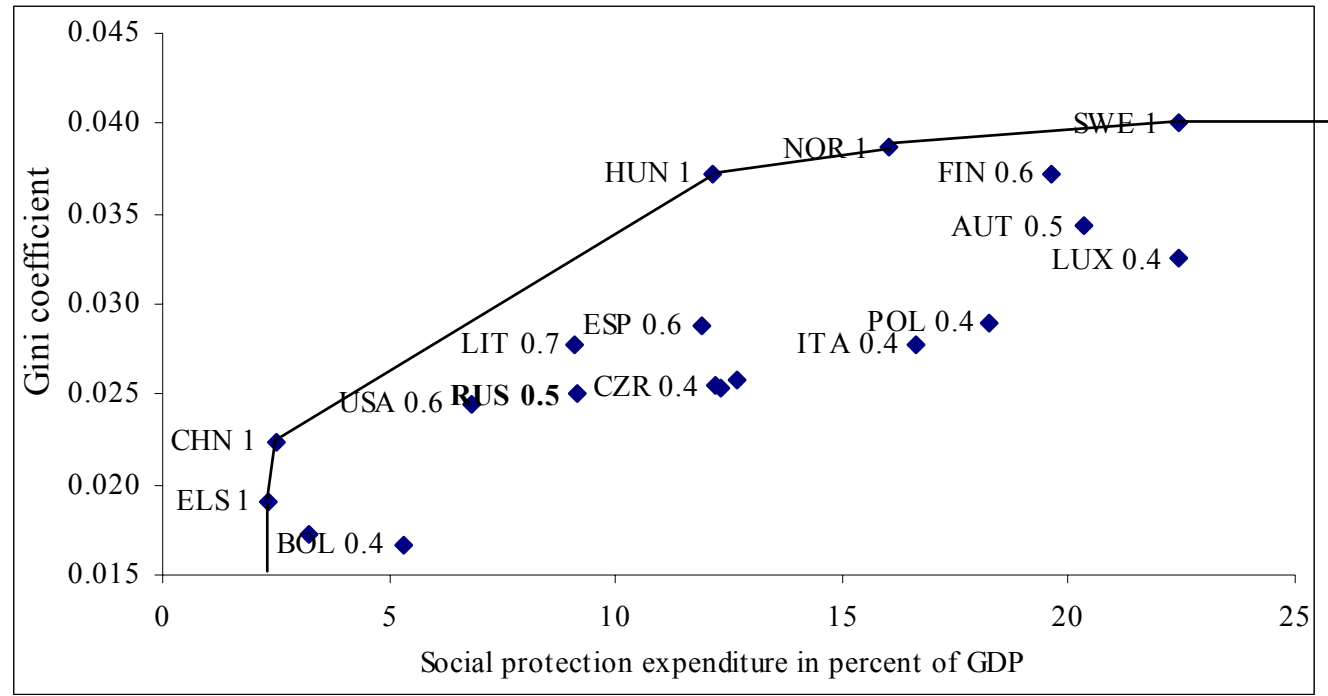

Sources: IMF, Government Finance Statistics, and WEO database, and Fund staff calculations; and World Bank, World Development Indicators. 
Figure 8. Local Governments-Income Level and Government Spending

(Selected transition economies; latest available observation)

(a) All Spending

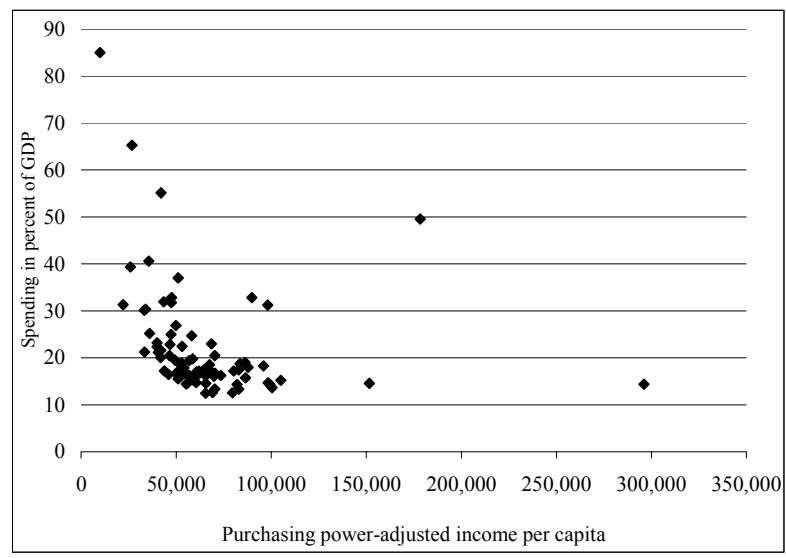

(c) Education

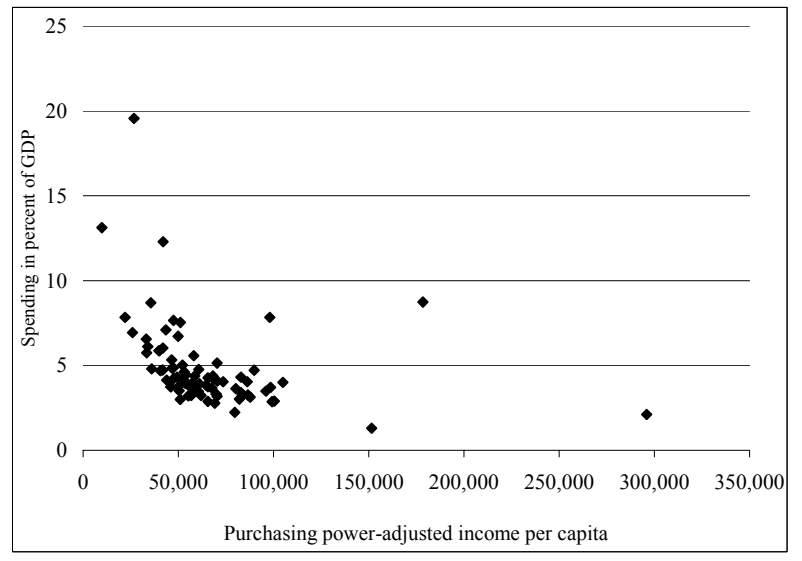

Sources: Rosstat; and Fund staff calculations. (b) Health

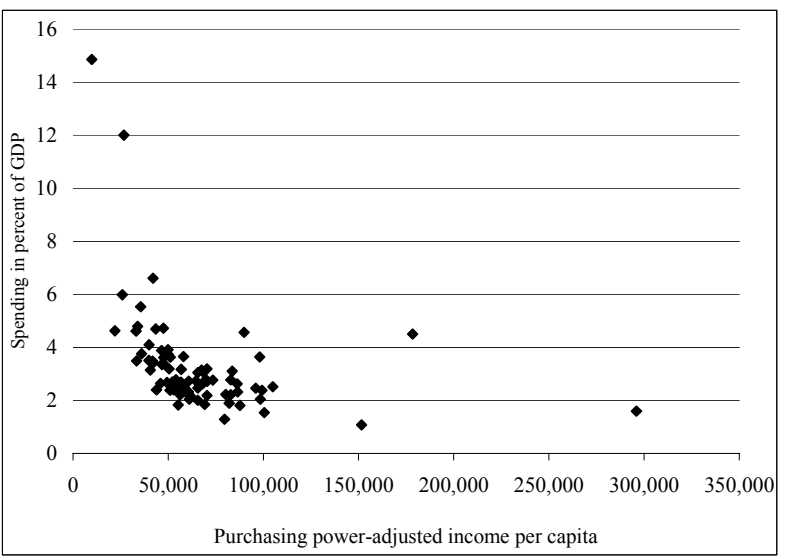

(d) Social Protection

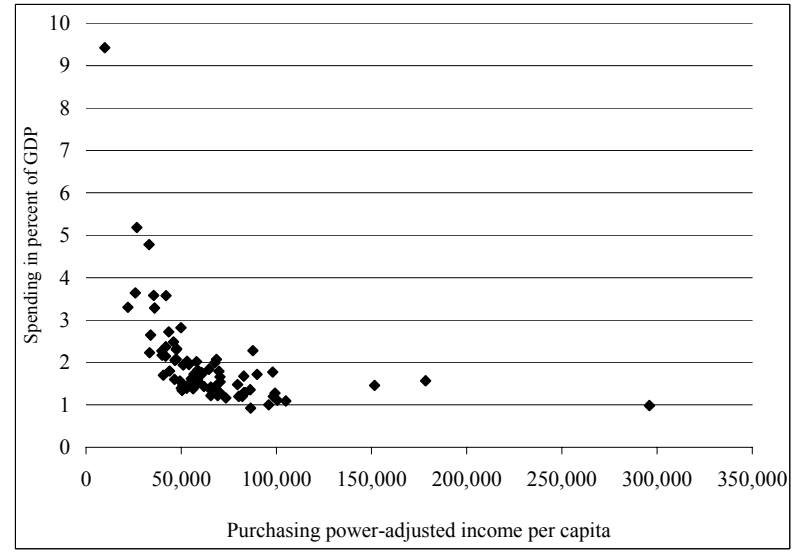


Figure 9. Local Governments-

PSP, PSE, and DEA Scores vs. Spending in Percent of GRP

PSP

Health

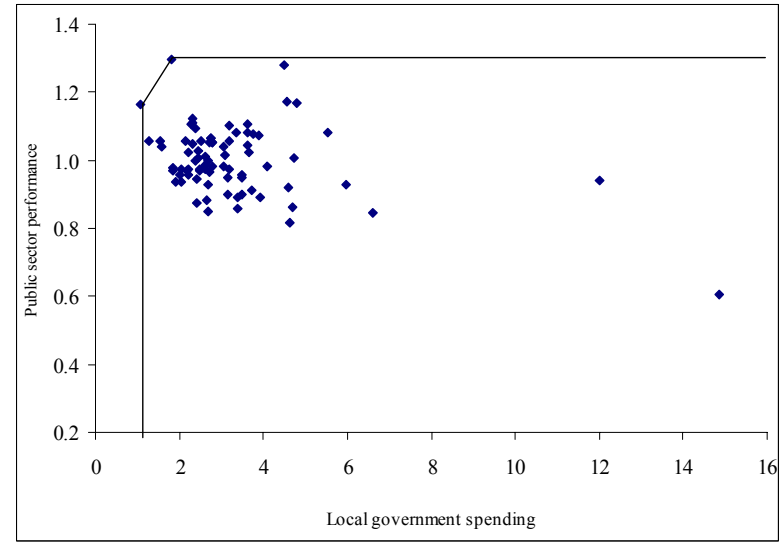

Education

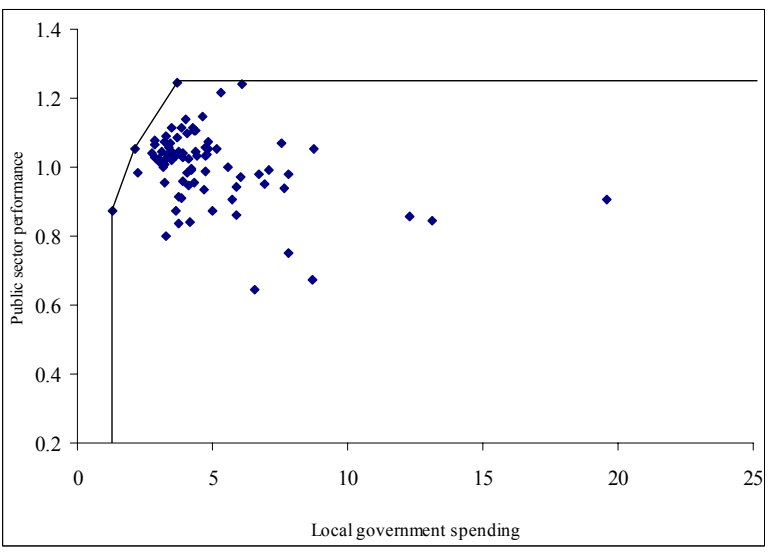

Social Protection

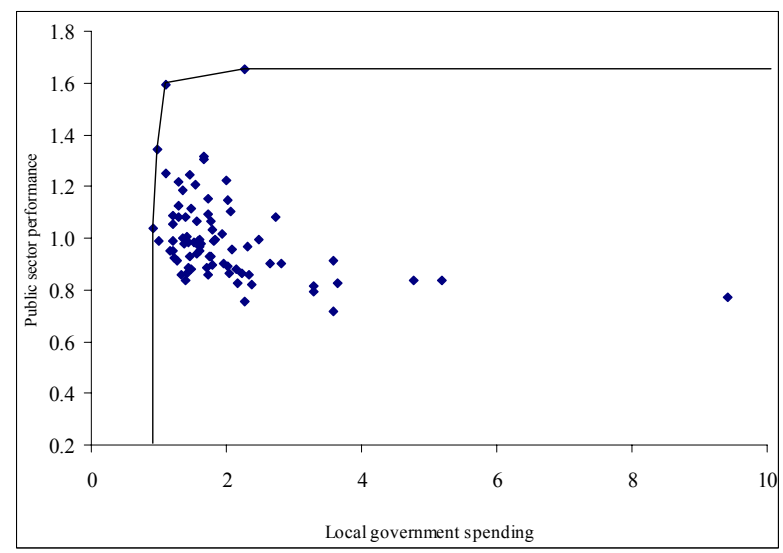

Sources: Rosstat; and Fund staff calculations.
PSE (filled markers) and DEA (empty markers) Health

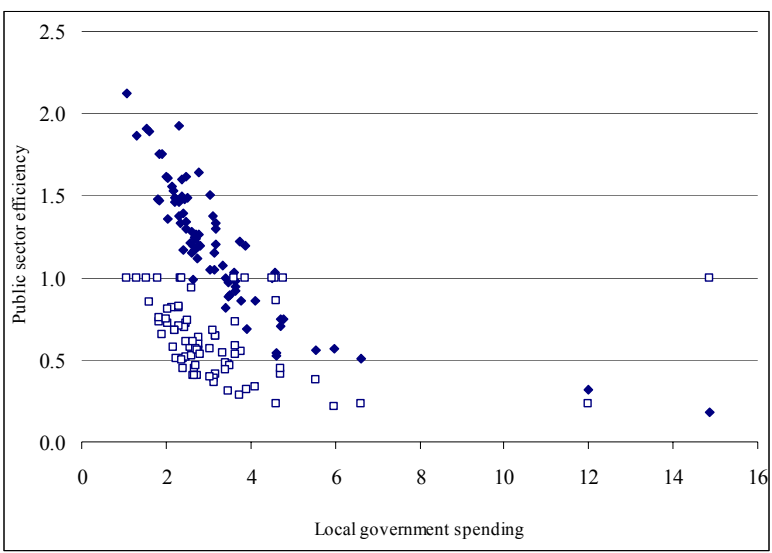

Education

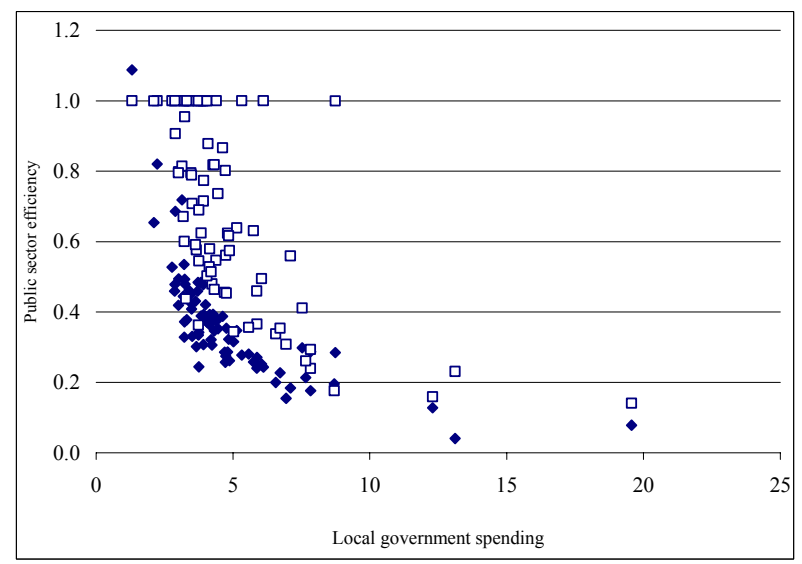

Social Protection

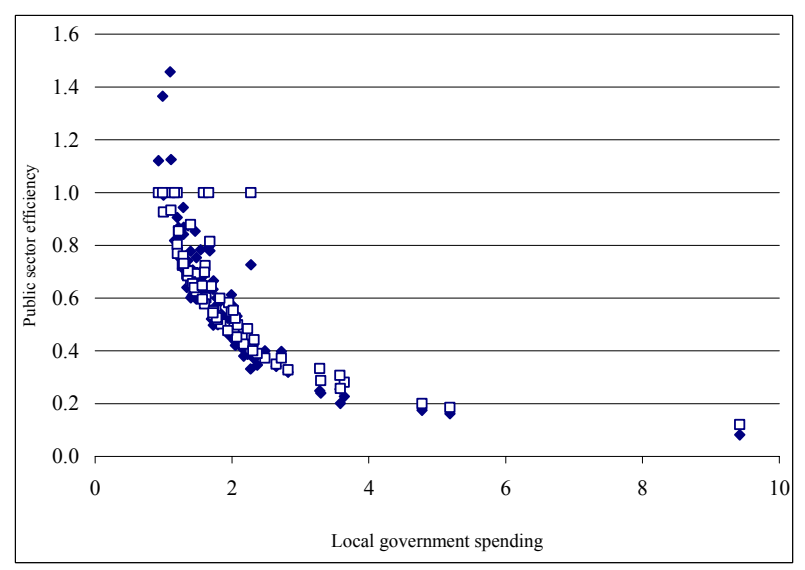




\section{APPENDIX I: Methodological Details}

55. The paper uses three concepts to measure public sector performance and efficiency: public sector performance (PSP), public sector efficiency (PSE) scores, both proposed by Afonso, Schuknecht, and Tanzi (2005; below referred to as "AST"), and data envelopment analysis (DEA) efficiency scores. All these concepts measure performance by outcome indicators that are assumed to be targeted by policy, and efficiency by relating performance to expenditure.

56. Slightly changing the definition in AST, PSP is defined, given country $i$ and $j$ areas of government performance, as

$$
P S P_{i}=\sum_{j=1}^{n} \omega_{j} P S P_{i j}
$$

where $\omega_{j}$ is a vector of weights determined by the societal welfare function, and $P S P_{i j}$ is a scalar that is a function of socioeconomic indicators. As the welfare function is unobserved, weights have to be assumed; following AST, equal weights are assumed for all $j$. This clearly introduces a strong assumption, but given the typically high correlation between outcome indicators, it turns out — as in AST - that different weights yield very similar results as measured by rank correlations. To aggregate the outcome indicators, the paper follows AST in dividing the outcome indicators by their respective standard deviation and then setting the mean to 1.

57. PSE is then calculated as the ratio of PSP to the respective expenditure $E X P_{i j}$ in percent of GDP, or

$$
P S E_{i}=\sum_{j=1}^{n} \frac{P S P_{i j}}{E X P_{i j}} .
$$

58. The DEA efficiency of public spending is measured by comparing actual spending with the minimum spending theoretically sufficient to produce the same actual output. ${ }^{29}$ The underlying theory was developed in Debreu (1951), Koopmans (1951), and Farrell (1957), and extended, in particular, by Färe, Grosskopf, and Lovell (1994). To the latter, the reader is referred to for a more extensive treatment of what can only be sketched here.

59. The efficiency concept here is more specifically "technical efficiency," defined as the ability of an entity to produce a given set of outputs with minimal inputs, independent of input prices and under the assumption of variable returns to scale. An example in Figure A1 illustrates this: say, one input $x$ is used to produce one output $y$. $C R S$ is the production possibilities frontier at constant returns to scale, $V R S$ is the production possibilities frontier at variable returns to scale, and NIRS is the production possibilities frontier at non-increasing returns to scale. Therefore, technical efficiency under variable returns to scale is

\footnotetext{
${ }^{29}$ We use this "input approach" as we focus on the level of expenditure; in any case, the alternative output approach tends to yield very similar results as measured by rank correlation. This finding is in line with those in AST; Afonso, Schuknecht, and Tanzi (2006); and Herrera and Pang (2005).
} 


$$
T_{V R S}=\frac{\overline{P\left(\lambda_{V} x^{A}\right)}}{\overline{P x^{A}}}=\lambda_{V},
$$

where $\lambda$ are the distances shown in Figure 1.

Figure A1. Technical Efficiency

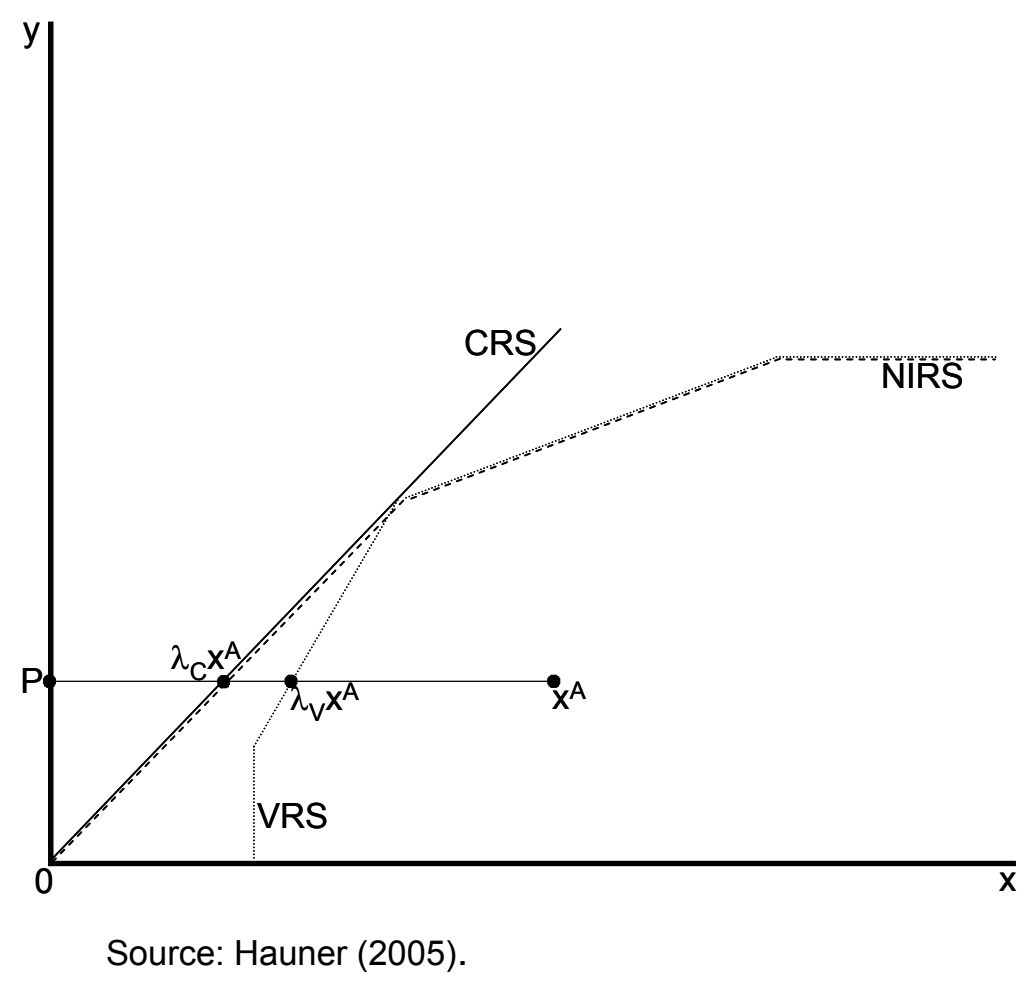

60. To calculate the efficiency scores, an empirical frontier is estimated. An entity is technically efficient if it lies on the frontier, implying a score of 1 . Note that efficiency defined as such is in fact only an upper bound of the "true" efficiency because the producers that are relatively the best may themselves have room for improvement. For the entities inside the frontier, efficient production sets are calculated as linear combinations of the production sets of efficient entities with similar output quantities. The scores for the inefficient entities are part of the set [0,1[, where a score of 0.7 implies that the same output could be theoretically produced with only 70 percent of the input.

61. To establish the frontier, the nonparametric DEA approach is used, as it is more adept than parametric approaches at describing frontiers as opposed to central tendencies. Instead of trying to fit a regression plane through the center of the data, DEA constructs a piecewise linear surface that connect the efficient entities, yielding a convex production possibilities set. DEA has been widely used in efficiency measurement, particularly in services industries, because it does not require the assumption of a particular functional form, deviations from which are misinterpreted as inefficiency by parametric techniques. However, DEA has the disadvantage of interpreting random errors as inefficiency, making it sensitive to outliers, and the results tend to be sensitive to the degrees of freedom. Recently, Simar and Wilson (2007) 
have proposed two algorithms to resolve some of these problems. However, as their Monte Carlo simulations yield similar results with and without the algorithms with $N=100$, and as Afonso and St. Aubyn (2006) also find "strikingly similar" results with and without them for $N=25$, the traditional approach is retained here, given that we have $N=79$.

62. The computation of the efficiency scores can be briefly sketched as follows. Given an $N x J$ input matrix, an $M x J$ output matrix, and a scaling vector $\phi$, the technical efficiency of unit $j$ 's production plan $\left(x^{j}, y^{j}\right)$ relative to those of the benchmark units $i=1 \ldots I$ (where $i \neq j$ ) under variable returns to scale can be calculated as the solution to

$$
\begin{aligned}
& \min _{\lambda \phi} \lambda \\
& \text { s.t. } y_{j m} \leq \sum_{i} \phi_{i} y_{i m}, m=1, \ldots, M \\
& \sum_{i} \phi_{i} x_{i n} \leq \lambda x_{j n}, n=1, \ldots, N . \\
& \phi_{i} \geq 0 \\
& \sum_{i} \phi_{i}=1 .
\end{aligned} .
$$

When all inputs have been cut by the highest proportion $\lambda$ possible for all of them at a given output, there could be remaining "slack" in some inputs. To account for the slacks $s$, (4) is changed to

$$
\begin{aligned}
& \min _{\lambda \phi} \lambda-\varepsilon\left(\sum_{m} s_{m}^{+}+\sum_{n} s_{n}^{-}\right) \\
& \text {s.t. } y_{j m}=\sum_{i} \phi_{i} y_{i m}-s_{m}^{+}, m=1, \ldots, M \\
& \sum_{i} \phi_{i} x_{i n}+s_{n}^{-}=\lambda x_{j n}, n=1, \ldots, N . \\
& \phi_{i} \geq 0 \\
& \sum_{i} \phi_{i}=1 .
\end{aligned}
$$

63. In the second stage of analysis, the PSP, PSE, and DEA scores are regressed on a set of potential correlates. The regressions take the form

$$
y_{i}=f\left(z_{i}\right)+\varepsilon_{i},
$$

where $y_{i}$ stands, alternatively, for the PSP, PSE, and DEA scores, $z_{i}$ is a set of correlates, and $\varepsilon_{i}$ is a continuous i.i.d. random variable uncorrelated with $z_{i}$. For the PSP and PSE scores, there is a choice between ordinary least squares OLS and two-stage least squares 2SLS. Given that tests on the OLS results (discussed below) show only very limited instances of endogeneity, OLS is used because it is more efficient. For the DEA scores, most previous studies used Tobit, usually based on the argument that the scores have a probability mass at 1 . However, Simar and Wilson (2007) argue that this property is an artifact in finite samples and that it is more appropriate to estimate truncated regressions with maximum 
likelihood assuming normally distributed error terms, an approach that is adopted here. The standard errors are always corrected for heteroscedasticity.

64. Two robustness checks seem particularly pertinent. First, several correlates might be endogenous. Specifically $A C A D E M I C$ could be influenced by education sector performance, EXPHEL/EXPEDU/EXPSOC/EXPTOT could be endogenous if lower efficiency leads to larger spending, and PRIVHEL/PRIVEDU could be endogenous if lower public sector raises private health and education spending. To test the null hypothesis of exogeneity of these variables, we perform a standard augmented regression test ${ }^{30}$ on our tested-down regression results but never reject exogeneity at the 10 percent significance level (see bottom line of Table A4). Second, the fact that the PSE ratios have public spending in the denominator may exert a bias when public expenditure is included as a regressor, given that PSP, the numerator of the PSE ratios, varies little. However, excluding public spending from the PSE regressions leaves 14 of the 18 remaining coefficients in the tested-down regressions (which exclude insignificant regressors) in Table A4 unchanged in sign and significance at conventional levels, thus providing little evidence of such a bias. Three of four cases where coefficients are affected concern $O L D$, and the fourth case concerns $A C A D E M I C$.

\footnotetext{
${ }^{30}$ First, the potentially endogenous variables are regressed on a constant and all other explanatory variables. Then, the residuals from these regressions are included as additional regressors in the tested-down regressions. If the coefficient on a residual is significantly different from zero, the null hypothesis of exogeneity is rejected.
} 


\section{APPENDIX II: Background Tables for Local Governments}

The background tables in this appendix present the details underlying the discussion in Section D on local governments. Table A1 shows the PSP, PSE, and DEA scores for each region in the health, education, and social protection sectors, as well as the aggregate of the three social sectors. Table A2 shows the univariate regressions underlying the discussion in paragraph 50 and Box 1, while Table A3 shows the corresponding multivariate regressions, and Table A4 the tested-down (that is, excluding the insignificant coefficients from Table A3) multivariate regressions. The variables are presented in Table 4 and Box 1, and the regression methodology is discussed in paragraphs 63-64 in Appendix I. 
Table A1. Scores by Region

\begin{tabular}{|c|c|c|c|c|c|c|c|c|c|c|c|c|}
\hline & \multicolumn{3}{|c|}{ Health } & \multicolumn{3}{|c|}{ Education } & & 11 Prote & & & $\mathrm{ial} \mathrm{Sec}$ & \\
\hline & PSP & PSE & DEA & PSP & PSE & DEA & PSP & PSE & DEA & PSP & PSE & DEA \\
\hline Adygeya Republic & 0.93 & 0.15 & 0.21 & 0.95 & 0.14 & 0.31 & 0.83 & 0.23 & 0.28 & 0.90 & 0.52 & 0.27 \\
\hline Altai Krai & 0.98 & 0.24 & 0.33 & 0.86 & 0.15 & 0.46 & 0.83 & 0.38 & 0.43 & 0.89 & 0.77 & 0.41 \\
\hline Altai Republic & 0.85 & 0.13 & 0.23 & 0.86 & 0.07 & 0.16 & 0.91 & 0.25 & 0.31 & 0.87 & 0.45 & 0.23 \\
\hline Amur Oblast & 1.02 & 0.28 & 0.53 & 1.00 & 0.18 & 0.36 & 1.15 & 0.57 & 0.55 & 1.06 & 1.03 & 0.48 \\
\hline Arkhangel'sk Oblast & 1.05 & 0.38 & 0.59 & 1.11 & 0.26 & 0.82 & 1.31 & 0.78 & 0.81 & 1.16 & 1.42 & 0.74 \\
\hline Astrakhan Oblast & 1.11 & 0.48 & 0.70 & 1.24 & 0.33 & 1.00 & 0.96 & 0.60 & 0.58 & 1.11 & 1.42 & 0.76 \\
\hline Bashkortostan Republic & 0.96 & 0.43 & 0.51 & 1.03 & 0.28 & 0.59 & 0.95 & 0.79 & 0.77 & 0.98 & 1.51 & 0.62 \\
\hline Belgorod Oblast & 1.05 & 0.45 & 1.00 & 1.07 & 0.31 & 0.80 & 0.93 & 0.53 & 0.56 & 1.02 & 1.29 & 0.78 \\
\hline Bryansk Oblast & 0.96 & 0.27 & 0.48 & 1.03 & 0.22 & 0.56 & 0.88 & 0.41 & 0.45 & 0.96 & 0.90 & 0.50 \\
\hline Buryat Republic & 0.89 & 0.23 & 0.31 & 0.98 & 0.15 & 0.35 & 0.90 & 0.32 & 0.33 & 0.92 & 0.69 & 0.33 \\
\hline Chelyabinsk Oblast & 0.96 & 0.48 & 0.75 & 1.06 & 0.37 & 1.00 & 1.00 & 0.74 & 0.68 & 1.01 & 1.59 & 0.81 \\
\hline Chitinsk Oblast & 1.01 & 0.21 & 0.41 & 0.94 & 0.12 & 0.26 & 0.97 & 0.42 & 0.40 & 0.97 & 0.76 & 0.36 \\
\hline Chukotsk A. Oblast & 1.28 & 0.28 & 1.00 & 1.05 & 0.12 & 1.00 & 1.07 & 0.68 & 0.60 & 1.13 & 1.09 & 0.87 \\
\hline Chuvash Republic & 1.08 & 0.32 & 0.54 & 1.07 & 0.22 & 0.62 & 0.86 & 0.42 & 0.52 & 1.01 & 0.97 & 0.56 \\
\hline Dagestan Republic & 0.82 & 0.18 & 0.86 & 0.75 & 0.10 & 0.24 & 0.79 & 0.24 & 0.29 & 0.79 & 0.51 & 0.46 \\
\hline Ingush Republic & 0.60 & 0.04 & 1.00 & 0.84 & 0.06 & 0.23 & 0.77 & 0.08 & 0.12 & 0.74 & 0.19 & 0.45 \\
\hline Irkutsk Oblast & 0.99 & 0.37 & 0.61 & 1.11 & 0.25 & 1.00 & 0.98 & 0.68 & 0.64 & 1.02 & 1.31 & 0.75 \\
\hline Ivanovo Oblast & 1.08 & 0.29 & 0.55 & 1.04 & 0.22 & 0.62 & 0.82 & 0.25 & 0.33 & 0.98 & 0.75 & 0.50 \\
\hline Jewish Autonomous O. & 0.86 & 0.18 & 0.44 & 0.99 & 0.14 & 0.56 & 1.08 & 0.40 & 0.37 & 0.98 & 0.72 & 0.46 \\
\hline Kabardino-Balkar R. & 0.90 & 0.26 & 0.31 & 0.90 & 0.16 & 0.63 & 0.86 & 0.39 & 0.48 & 0.89 & 0.80 & 0.47 \\
\hline Kaliningrad Oblast & 0.88 & 0.36 & 0.51 & 1.02 & 0.25 & 0.53 & 1.08 & 0.78 & 0.88 & 0.99 & 1.39 & 0.64 \\
\hline Kalmykiya Republic & 1.08 & 0.20 & 0.38 & 0.67 & 0.08 & 0.18 & 0.72 & 0.20 & 0.26 & 0.83 & 0.47 & 0.27 \\
\hline Kaluzhska Oblast & 0.98 & 0.38 & 0.58 & 1.04 & 0.24 & 0.55 & 0.99 & 0.54 & 0.60 & 1.00 & 1.16 & 0.57 \\
\hline Kamchatka Oblast & 1.08 & 0.30 & 0.73 & 1.07 & 0.14 & 0.41 & 1.02 & 0.52 & 0.48 & 1.06 & 0.96 & 0.54 \\
\hline Karachaev-Circassian R. & 0.92 & 0.20 & 0.23 & 0.64 & 0.10 & 0.34 & 0.84 & 0.18 & 0.20 & 0.80 & 0.47 & 0.26 \\
\hline Karelian Republic & 1.10 & 0.35 & 0.64 & 1.05 & 0.21 & 0.64 & 1.32 & 0.79 & 1.00 & 1.16 & 1.35 & 0.76 \\
\hline Kemerovo Oblast & 0.97 & 0.35 & 0.41 & 0.99 & 0.21 & 0.45 & 1.15 & 0.67 & 0.55 & 1.04 & 1.23 & 0.47 \\
\hline Khabarovsk Krai & 0.98 & 0.32 & 0.39 & 0.99 & 0.24 & 0.51 & 1.10 & 0.53 & 0.45 & 1.03 & 1.09 & 0.45 \\
\hline Khakasian Republic & 0.85 & 0.32 & 0.47 & 0.87 & 0.17 & 0.34 & 1.01 & 0.71 & 0.65 & 0.91 & 1.20 & 0.49 \\
\hline Kirov Oblast & 1.07 & 0.28 & 1.00 & 1.22 & 0.23 & 1.00 & 0.95 & 0.59 & 0.70 & 1.08 & 1.10 & 0.90 \\
\hline Komi Republic & 1.06 & 0.42 & 0.73 & 1.14 & 0.28 & 1.00 & 1.60 & 1.46 & 1.00 & 1.26 & 2.16 & 0.91 \\
\hline Kostromska Oblast & 1.01 & 0.39 & 0.94 & 1.15 & 0.25 & 0.87 & 0.89 & 0.44 & 0.49 & 1.02 & 1.08 & 0.76 \\
\hline Krasnodarsk Krai & 1.00 & 0.37 & 0.44 & 1.02 & 0.32 & 1.00 & 0.86 & 0.50 & 0.54 & 0.96 & 1.19 & 0.66 \\
\hline Krasnoyarsk Krai & 0.97 & 0.37 & 0.53 & 0.98 & 0.24 & 0.50 & 1.19 & 0.87 & 0.70 & 1.05 & 1.49 & 0.58 \\
\hline Kurgan Oblast & 0.86 & 0.25 & 0.43 & 0.97 & 0.16 & 0.49 & 0.82 & 0.35 & 0.39 & 0.88 & 0.76 & 0.44 \\
\hline Kursk Oblast & 0.98 & 0.53 & 0.73 & 1.01 & 0.31 & 1.00 & 0.98 & 0.61 & 0.60 & 0.99 & 1.46 & 0.78 \\
\hline Leningrad Oblast & 0.94 & 0.49 & 0.66 & 1.02 & 0.34 & 0.80 & 0.99 & 0.82 & 1.00 & 0.98 & 1.66 & 0.82 \\
\hline Lipetsk Oblast & 1.09 & 0.46 & 1.00 & 1.08 & 0.38 & 1.00 & 0.91 & 0.71 & 0.72 & 1.03 & 1.55 & 0.91 \\
\hline Magadan Oblast & 1.17 & 0.26 & 1.00 & 1.06 & 0.22 & 0.80 & 1.09 & 0.63 & 0.54 & 1.11 & 1.11 & 0.78 \\
\hline Marii-El Republic & 0.95 & 0.27 & 0.46 & 0.94 & 0.16 & 0.37 & 0.75 & 0.33 & 0.41 & 0.88 & 0.76 & 0.41 \\
\hline Mordoviya Republic & 1.10 & 0.31 & 1.00 & 1.00 & 0.24 & 0.48 & 0.86 & 0.37 & 0.44 & 0.99 & 0.91 & 0.64 \\
\hline Moscow & 1.16 & 1.09 & 1.00 & 0.87 & 0.67 & 1.00 & 1.25 & 0.85 & 0.68 & 1.09 & 2.61 & 0.89 \\
\hline Moscow Oblast & 0.95 & 0.30 & 0.39 & 0.87 & 0.24 & 0.58 & 1.22 & 0.61 & 0.55 & 1.01 & 1.15 & 0.50 \\
\hline Murmansk Oblast & 1.05 & 0.39 & 0.57 & 0.95 & 0.23 & 0.88 & 1.21 & 0.78 & 0.65 & 1.07 & 1.40 & 0.70 \\
\hline N. Ossetian-Alaniya R. & 1.17 & 0.24 & 1.00 & 1.24 & 0.20 & 1.00 & 0.90 & 0.34 & 0.35 & 1.10 & 0.79 & 0.78 \\
\hline Nizhegorod Oblast & 0.97 & 0.53 & 0.76 & 1.04 & 0.37 & 1.00 & 1.06 & 0.87 & 0.85 & 1.02 & 1.77 & 0.87 \\
\hline Novgorod Oblast & 0.97 & 0.48 & 0.81 & 0.96 & 0.25 & 1.00 & 0.93 & 0.53 & 0.53 & 0.96 & 1.26 & 0.78 \\
\hline Novosibirsk Oblast & 1.06 & 0.39 & 0.55 & 0.91 & 0.24 & 0.62 & 0.99 & 0.54 & 0.50 & 0.99 & 1.17 & 0.56 \\
\hline Omsk Oblast & 1.05 & 0.38 & 0.53 & 1.04 & 0.31 & 1.00 & 1.03 & 0.58 & 0.52 & 1.04 & 1.27 & 0.68 \\
\hline Orenburg Oblast & 1.04 & 0.34 & 0.57 & 0.92 & 0.24 & 0.55 & 0.92 & 0.76 & 0.85 & 0.96 & 1.34 & 0.66 \\
\hline Orlov Oblast & 0.97 & 0.39 & 0.61 & 1.11 & 0.26 & 0.82 & 0.86 & 0.61 & 0.65 & 0.98 & 1.26 & 0.69 \\
\hline Penza Oblast & 0.90 & 0.29 & 0.36 & 0.94 & 0.20 & 0.46 & 0.88 & 0.52 & 0.64 & 0.91 & 1.01 & 0.49 \\
\hline Perm Oblast & 1.02 & 0.46 & 0.68 & 1.06 & 0.31 & 1.00 & 1.08 & 0.84 & 0.73 & 1.05 & 1.61 & 0.80 \\
\hline Primorye Krai & 0.93 & 0.35 & 0.40 & 0.96 & 0.22 & 0.46 & 0.94 & 0.60 & 0.65 & 0.94 & 1.17 & 0.50 \\
\hline Pskov Oblast & 0.89 & 0.26 & 0.48 & 1.05 & 0.22 & 0.57 & 0.96 & 0.46 & 0.50 & 0.97 & 0.94 & 0.52 \\
\hline Rostov Oblast & 0.88 & 0.33 & 0.41 & 0.84 & 0.22 & 0.36 & 0.99 & 0.40 & 0.37 & 0.90 & 0.96 & 0.38 \\
\hline Ryazan Oblast & 1.06 & 0.49 & 0.82 & 1.07 & 0.33 & 0.95 & 0.89 & 0.62 & 0.70 & 1.01 & 1.44 & 0.82 \\
\hline Saint Petersburg & 1.30 & 0.72 & 1.00 & 1.04 & 0.33 & 0.81 & 1.65 & 0.73 & 1.00 & 1.33 & 1.78 & 0.94 \\
\hline Sakha R. (Yakutiya) & 1.04 & 0.29 & 0.58 & 0.98 & 0.12 & 0.29 & 1.07 & 0.60 & 0.53 & 1.03 & 1.01 & 0.47 \\
\hline Sakhalin Oblast & 1.02 & 0.33 & 0.68 & 0.95 & 0.30 & 0.60 & 1.12 & 0.87 & 0.73 & 1.03 & 1.49 & 0.67 \\
\hline Samara Oblast & 1.06 & 0.82 & 1.00 & 0.98 & 0.44 & 1.00 & 1.12 & 0.75 & 0.64 & 1.05 & 2.02 & 0.88 \\
\hline Saratov Oblast & 1.00 & 0.42 & 0.49 & 1.02 & 0.34 & 0.80 & 0.93 & 0.64 & 0.69 & 0.98 & 1.39 & 0.66 \\
\hline Smolensk Oblast & 1.12 & 0.48 & 0.82 & 1.11 & 0.29 & 1.00 & 0.98 & 0.64 & 0.64 & 1.07 & 1.42 & 0.82 \\
\hline Stavropol Krai & 0.94 & 0.39 & 0.45 & 0.84 & 0.20 & 0.58 & 0.90 & 0.50 & 0.53 & 0.89 & 1.09 & 0.52 \\
\hline Sverdlovsk Oblast & 0.97 & 0.44 & 0.57 & 1.00 & 0.31 & 0.67 & 1.22 & 0.94 & 0.76 & 1.06 & 1.70 & 0.67 \\
\hline Tambov Oblast & 0.98 & 0.39 & 0.72 & 1.04 & 0.26 & 0.77 & 0.88 & 0.60 & 0.63 & 0.97 & 1.25 & 0.71 \\
\hline Tatarstan Republic & 1.01 & 0.41 & 0.51 & 1.05 & 0.30 & 0.79 & 0.99 & 0.99 & 0.93 & 1.01 & 1.70 & 0.74 \\
\hline Tomsk Oblast & 1.06 & 0.69 & 1.00 & 1.03 & 0.36 & 0.91 & 1.25 & 1.12 & 0.93 & 1.11 & 2.17 & 0.95 \\
\hline Tula Oblast & 0.98 & 0.31 & 0.65 & 1.03 & 0.26 & 0.72 & 0.99 & 0.62 & 0.72 & 1.00 & 1.19 & 0.69 \\
\hline Tver Oblast & 1.03 & 0.42 & 0.70 & 1.11 & 0.32 & 1.00 & 0.99 & 0.62 & 1.00 & 1.04 & 1.37 & 0.90 \\
\hline Tyumen Oblast & 1.04 & 0.65 & 0.85 & 1.05 & 0.50 & 1.00 & 1.34 & 1.37 & 1.00 & 1.15 & 2.52 & 0.95 \\
\hline Tyva Republic & 0.94 & 0.08 & 0.23 & 0.91 & 0.05 & 0.14 & 0.84 & 0.16 & 0.19 & 0.90 & 0.29 & 0.19 \\
\hline Udmurt Republic & 1.07 & 0.39 & 0.63 & 1.10 & 0.27 & 1.00 & 0.95 & 0.82 & 1.00 & 1.04 & 1.47 & 0.88 \\
\hline Ulyanov Oblast & 0.91 & 0.24 & 0.29 & 1.05 & 0.28 & 0.69 & 0.84 & 0.60 & 0.66 & 0.93 & 1.12 & 0.55 \\
\hline Vladimir Oblast & 0.98 & 0.35 & 0.56 & 1.03 & 0.23 & 0.74 & 0.90 & 0.46 & 0.58 & 0.97 & 1.05 & 0.63 \\
\hline Volgograd Oblast & 0.97 & 0.44 & 0.68 & 0.80 & 0.24 & 0.44 & 0.98 & 0.71 & 0.69 & 0.92 & 1.39 & 0.60 \\
\hline Vologodsk Oblast & 0.94 & 0.46 & 0.72 & 1.09 & 0.29 & 1.00 & 1.09 & 0.91 & 0.80 & 1.04 & 1.66 & 0.84 \\
\hline Voronezh Oblast & 1.06 & 0.33 & 0.42 & 1.02 & 0.29 & 0.71 & 0.86 & 0.64 & 0.69 & 0.98 & 1.26 & 0.60 \\
\hline Yaroslavl Oblast & 1.11 & 0.48 & 0.83 & 1.09 & 0.34 & 1.00 & 1.04 & 1.12 & 1.00 & 1.08 & 1.93 & 0.94 \\
\hline
\end{tabular}

Source: Fund staff calculations. 
Table A2. Local Governments-Univariate Regressions of Scores

\begin{tabular}{|c|c|c|c|c|c|c|c|c|c|c|c|c|}
\hline \multirow[t]{2}{*}{ Dependent Variable } & \multicolumn{3}{|c|}{ Health } & \multicolumn{3}{|c|}{ Education } & \multicolumn{3}{|c|}{ Social Protection } & \multicolumn{3}{|c|}{ Social Sectors } \\
\hline & PSP & PSE & DEA & PSP & PSE & DEA & PSP & PSE & DEA & PSP & PSE & DEA \\
\hline INCPERCAP & $\begin{array}{c}1.2 \mathrm{E}-6^{* *} \\
(0.04,0.19)\end{array}$ & $\begin{array}{c}2.4 \mathrm{E}-6 * * * \\
(0.01,0.32)\end{array}$ & $\begin{array}{c}6.0 \mathrm{E}-6^{* * *} \\
(0.00,0.19)\end{array}$ & $\begin{array}{c}7.0 \mathrm{E}-7 * * \\
(0.06,0.06)\end{array}$ & $\begin{array}{c}1.5 \mathrm{E}-6^{* * * *} \\
(0.00,0.33)\end{array}$ & $\begin{array}{c}0.00 \\
(0.11,0.37)\end{array}$ & $\begin{array}{l}-1.9 \mathrm{E}-6 * * * \\
(0.01,0.22)\end{array}$ & $\begin{array}{l}2.1 \mathrm{E}-6^{* * *} \\
(0.00,0.21)\end{array}$ & $\begin{array}{c}1.2 \mathrm{E}-6^{* * *} \\
(0.00,0.50)\end{array}$ & $\begin{array}{c}0.00 \\
(0.96,0.00)\end{array}$ & $\begin{array}{c}6.0 \mathrm{E}-6^{* * *} \\
(0.00,0.35)\end{array}$ & $\begin{array}{c}6.4 \mathrm{E}-6^{* * *} \\
(0.00,0.49)\end{array}$ \\
\hline FUEL & $\begin{array}{c}0.00 \\
(0.87,0)\end{array}$ & $\begin{array}{c}0.00 \\
(0.21,0.02)\end{array}$ & $\begin{array}{c}0.00 \\
(0.17,0.02)\end{array}$ & $\begin{array}{c}0.00 \\
(0.90,0.00)\end{array}$ & $\begin{array}{c}0.00 \\
(0.15,0.04)\end{array}$ & $\begin{array}{c}0.00 \\
(0.80,0.00)\end{array}$ & $\begin{array}{c}0.00 \\
(0.75,0.00)\end{array}$ & $\begin{array}{c}2.6 \mathrm{E}-3 * * \\
(0.04,0.07)\end{array}$ & $\begin{array}{c}0.01 * \\
(0.08,0.07)\end{array}$ & $\begin{array}{c}0.00 \\
(0.66,0.00)\end{array}$ & $\begin{array}{c}5.0 \mathrm{E}-3 * \\
(0.07,0.05)\end{array}$ & $\begin{array}{c}0.00 \\
(0.12,0.03)\end{array}$ \\
\hline$A L C T O B$ & $\begin{array}{c}4.7 \mathrm{E}-2 * * \\
(0.02,0.13)\end{array}$ & $\begin{array}{c}0.00 \\
(0.84,0.00)\end{array}$ & $\begin{array}{c}0.01 \\
(0.91,0.00)\end{array}$ & $\begin{array}{c}0.03 * \\
(0.07,0.05)\end{array}$ & $\begin{array}{c}0.00 \\
(0.85,0.00)\end{array}$ & $\begin{array}{c}38.75 \\
(0.38,0.02)\end{array}$ & $\begin{array}{c}-0.07 * * * \\
(0.00,0.14)\end{array}$ & $\begin{array}{c}0.01 \\
(0.65,0.00)\end{array}$ & $\begin{array}{c}0.07 \\
(0.20,0.04)\end{array}$ & $\begin{array}{c}0.00 \\
(0.89,0.00)\end{array}$ & $\begin{array}{c}0.01 \\
(0.83,0.00)\end{array}$ & $\begin{array}{c}0.05 \\
(0.19,0.02)\end{array}$ \\
\hline$O L D$ & $\begin{array}{c}0.00 \\
(0.61,0.01)\end{array}$ & $\begin{array}{c}0.01 * * * \\
(0.00,0.13)\end{array}$ & $\begin{array}{c}0.00 \\
(0.79,0.00)\end{array}$ & $\begin{array}{c}0.01 * * * \\
(0.01,0.07)\end{array}$ & $\begin{array}{c}0.01 * * * \\
(0.00,0.20)\end{array}$ & $\begin{array}{c}0.03 * * * \\
(0.00,0.29)\end{array}$ & $\begin{array}{c}0.00 \\
(0.87,0.00)\end{array}$ & $\begin{array}{c}0.01 * * * \\
(0.01,0.11)\end{array}$ & $\begin{array}{c}0.02^{* *} \\
(0.03,0.08)\end{array}$ & $\begin{array}{c}2.6 \mathrm{E}-3^{*} \\
(0.07,0.04)\end{array}$ & $\begin{array}{c}0.03^{* * *} \\
(0.00,0.17)\end{array}$ & $\begin{array}{c}0.02 * * \\
(0.03,0.08)\end{array}$ \\
\hline DENSITY & $\begin{array}{c}0.00 \\
(0.80,0.00)\end{array}$ & $\begin{array}{c}0.00 \\
(0.20,0.12)\end{array}$ & $\begin{array}{c}0.00 \\
(0.57,0.01)\end{array}$ & $\begin{array}{l}-3.0 \mathrm{E}-4 * * * \\
(0.01,0.02)\end{array}$ & $\begin{array}{c}0.00 \\
(0.11,0.14)\end{array}$ & $\begin{array}{c}0.44 \\
(0.54,0.01)\end{array}$ & $\begin{array}{c}0.00 \\
(0.57,0.01)\end{array}$ & $\begin{array}{c}0.00 \\
(0.97,0.00)\end{array}$ & $\begin{array}{c}0.00 \\
(0.90,0.00)\end{array}$ & $\begin{array}{c}0.00 \\
(0.96,0.00)\end{array}$ & $\begin{array}{c}0.00 \\
(0.27,0.06)\end{array}$ & $\begin{array}{c}0.00 \\
(0.51,0.01)\end{array}$ \\
\hline TEMPJAN & $\begin{array}{c}0.00 \\
(0.27,0.02)\end{array}$ & $\begin{array}{c}0.00 \\
(0.36,0.01)\end{array}$ & $\begin{array}{c}0.00 \\
(0.55,0.01)\end{array}$ & $\begin{array}{c}0.00 \\
(0.50,0.01)\end{array}$ & $\begin{array}{c}0.00 \\
(0.13,0.03)\end{array}$ & $\begin{array}{c}0.00 \\
(0.32,0.02)\end{array}$ & $\begin{array}{c}0.01 * * * \\
(0.00,0.16)\end{array}$ & $\begin{array}{c}0.00 \\
(0.40,0.01)\end{array}$ & $\begin{array}{c}0.00 \\
(0.82,0.00)\end{array}$ & $\begin{array}{c}1.6 \mathrm{E}-3^{* *} \\
(0.05,0.05)\end{array}$ & $\begin{array}{c}0.01 \\
(0.28,0.02)\end{array}$ & $\begin{array}{c}0.00 \\
(0.48,0.01)\end{array}$ \\
\hline MOSCOW & $\begin{array}{c}0.00 \\
(0.85,0.00)\end{array}$ & $\begin{array}{c}-1.7 \mathrm{E}-5 * * * \\
(0.00,0.09)\end{array}$ & $\begin{array}{c}0.00 \\
(0.24,0.02)\end{array}$ & $\begin{array}{c}0.00 \\
(0.16,0.01)\end{array}$ & $\begin{array}{l}-1.3 \mathrm{E}-5 * * * \\
(0.00,0.14)\end{array}$ & $\begin{array}{l}-2.8 \mathrm{E}-5 * * * \\
(0.00,0.12)\end{array}$ & $\begin{array}{c}-1.2 \mathrm{E}-5 * * * \\
(0.00,0.05)\end{array}$ & $\begin{array}{l}-1.7 \mathrm{E}-5 * * * \\
(0.00,0.07)\end{array}$ & $\begin{array}{c}-2.4 \mathrm{E}-5 * * * \\
(0.01,0.05)\end{array}$ & $\begin{array}{c}-5.2 \mathrm{E}-6^{* *} \\
(0.03,0.06)\end{array}$ & $\begin{array}{c}-4.7 \mathrm{E}-5^{* * *} \\
(0.00,0.12)\end{array}$ & $\begin{array}{c}-2.5 \mathrm{E}-5^{* * * *} \\
(0.00,0.08)\end{array}$ \\
\hline POPULATION & $\begin{array}{c}0.00 \\
(0.37,0.01)\end{array}$ & $\begin{array}{c}5.7 \mathrm{E}-5^{* * *} \\
(0.00,0.35)\end{array}$ & $\begin{array}{c}0.00 \\
(0.58,0.01)\end{array}$ & $\begin{array}{c}0.00 \\
(0.16,0.02)\end{array}$ & $\begin{array}{c}3.7 \mathrm{E}-5 * * * \\
(0.00,0.37)\end{array}$ & $\begin{array}{c}0.00 \\
(0.13,0.04)\end{array}$ & $\begin{array}{c}0.00 \\
(0.19,0.03)\end{array}$ & $\begin{array}{c}2.6 \mathrm{E}-5 * * \\
(0.03,0.06)\end{array}$ & $\begin{array}{c}5.3 \mathrm{E}-5^{*} \\
(0.07,0.08)\end{array}$ & $\begin{array}{c}0.00 \\
(0.25,0.03)\end{array}$ & $\begin{array}{c}1.2 \mathrm{E}-4 * * * \\
(0.00,0.27)\end{array}$ & $\begin{array}{c}3.9 \mathrm{E}-5^{*} \\
(0.07,0.05)\end{array}$ \\
\hline TRANSFERS & $\begin{array}{l}-2.2 \mathrm{E}-3 * * * \\
(0.00,0.19)\end{array}$ & $\begin{array}{c}-0.01^{* * *} \\
(0.00,0.60)\end{array}$ & $\begin{array}{c}-0.01 * * \\
(0.02,0.11)\end{array}$ & $\begin{array}{r}-1.8 \mathrm{E}-3 * * * \\
(0.01,0.12)\end{array}$ & $\begin{array}{l}-3.8 \mathrm{E}-3 * * * \\
(0.00,0.63)\end{array}$ & $\begin{array}{c}-0.03 \\
(0.12,0.37)\end{array}$ & $\begin{array}{c}4.3 \mathrm{E}-3 * * * \\
(0.00,0.34)\end{array}$ & $\begin{array}{c}-0.01 * * * \\
(0.00,0.43)\end{array}$ & $\begin{array}{c}-0.01 * * * \\
(0.00,0.58)\end{array}$ & $\begin{array}{c}0.00 \\
(0.79,0.00)\end{array}$ & $\begin{array}{c}-0.02 * * * \\
(0.00,0.69)\end{array}$ & $\begin{array}{c}-0.01 * * * \\
(0.00,0.48)\end{array}$ \\
\hline RISK & $\begin{array}{c}0.00 \\
(0.72,0.00)\end{array}$ & $\begin{array}{c}-0.06^{* * *} \\
(0.00,0.19)\end{array}$ & $\begin{array}{c}-0.01 \\
(0.81,0.00)\end{array}$ & $\begin{array}{c}-0.02 \\
(0.15,0.03)\end{array}$ & $\begin{array}{c}-0.05 * * * \\
(0.00,0.27)\end{array}$ & $\begin{array}{c}-0.09 * * * \\
(0.00,0.21)\end{array}$ & $\begin{array}{c}0.04 * * \\
(0.04,0.07)\end{array}$ & $\begin{array}{c}-0.08 * * * \\
(0.00,0.27)\end{array}$ & $\begin{array}{c}-0.13 * * * \\
(0.00,0.30)\end{array}$ & $\begin{array}{c}0.00 \\
(0.44,0.01)\end{array}$ & $\begin{array}{c}-0.19 * * * \\
(0.00,0.30)\end{array}$ & $\begin{array}{c}-0.08 * * * \\
(0.00,0.14)\end{array}$ \\
\hline SHADOW & $\begin{array}{l}-4.2 \mathrm{E}-3 * * \\
(0.03,0.12)\end{array}$ & $\begin{array}{c}0.00 \\
(0.89,0.00)\end{array}$ & $\begin{array}{c}0.00 \\
(0.77,0.00)\end{array}$ & $\begin{array}{l}-4.4 \mathrm{E}-3 * * * \\
(0.00,0.11)\end{array}$ & $\begin{array}{c}0.00 \\
(0.96,0.00)\end{array}$ & $\begin{array}{c}-0.01 * \\
(0.06,0.06)\end{array}$ & $\begin{array}{c}0.00 \\
(0.28,0.03)\end{array}$ & $\begin{array}{c}-4.7 \mathrm{E}-3 * \\
(0.06,0.05)\end{array}$ & $\begin{array}{c}-0.01 * \\
(0.07,0.06)\end{array}$ & $\begin{array}{l}-1.9 \mathrm{E}-3 * * * \\
(0.01,0.07)\end{array}$ & $\begin{array}{c}0.00 \\
(0.58,0.01)\end{array}$ & $\begin{array}{c}-0.01 \\
(0.11,0.03)\end{array}$ \\
\hline ACADEMIC & $\begin{array}{c}0.00 \\
(0.84,0.00)\end{array}$ & $\begin{array}{c}0.01 \\
(0.44,0.04)\end{array}$ & $\begin{array}{c}0.02 * * \\
(0.04,0.07)\end{array}$ & $\begin{array}{c}-4.7 \mathrm{E}-3^{* *} \\
(0.04,0.05)\end{array}$ & $\begin{array}{c}0.00 \\
(0.69,0.01)\end{array}$ & $\begin{array}{c}0.00 \\
(0.56,0.01)\end{array}$ & $\begin{array}{c}0.00 \\
(0.38,0.03)\end{array}$ & $\begin{array}{c}-0.01 * \\
(0.09,0.06)\end{array}$ & $\begin{array}{c}-0.01 \\
(0.27,0.03)\end{array}$ & $\begin{array}{c}0.00 \\
(0.78,0.00)\end{array}$ & $\begin{array}{c}0.00 \\
(0.98,0.00)\end{array}$ & $\begin{array}{c}0.00 \\
(0.82,0.00)\end{array}$ \\
\hline$U R B A N$ & $\begin{array}{c}3.8 \mathrm{E}-3 * * * \\
(0.00,0.22)\end{array}$ & $\begin{array}{c}0.01^{* * *} \\
(0.00,0.34)\end{array}$ & $\begin{array}{c}0.01 * * * \\
(0.01,0.11)\end{array}$ & $\begin{array}{l}3.4 \mathrm{E}-3 * * * \\
(0.00,0.16)\end{array}$ & $\begin{array}{l}4.6 \mathrm{E}-3 * * * \\
(0.00,0.35)\end{array}$ & $\begin{array}{c}0.09 \\
(0.60,0.27)\end{array}$ & $\begin{array}{c}-0.01 * * * \\
(0.00,0.39)\end{array}$ & $\begin{array}{c}4.2 \mathrm{E}-3 * * \\
(0.02,0.10)\end{array}$ & $\begin{array}{c}0.01 * * * \\
(0.00,0.33)\end{array}$ & $\begin{array}{c}0.00 \\
(0.90,0.00)\end{array}$ & $\begin{array}{c}0.02 * * * \\
(0.00,0.29)\end{array}$ & $\begin{array}{c}0.01 * * * \\
(0.00,0.32)\end{array}$ \\
\hline $\begin{array}{l}\text { EXPHEL/EXPEDU/ } \\
\text { EXPSOC/EXPTOT } 1 /\end{array}$ & $\begin{array}{c}-0.02 * * * \\
(0.01,0.17)\end{array}$ & $\begin{array}{c}-0.05^{* * *} \\
(0.00,0.47)\end{array}$ & $\begin{array}{c}-0.03 \\
(0.42,0.03)\end{array}$ & $\begin{array}{c}-0.01 * * * \\
(0.00,0.11)\end{array}$ & $\begin{array}{c}-0.03 * * * \\
(0.00,0.59)\end{array}$ & $\begin{array}{c}-0.25^{*} \\
(0.10,0.42)\end{array}$ & $\begin{array}{c}0.08^{* * * *} \\
(0.00,0.37)\end{array}$ & $\begin{array}{c}-0.11 * * * \\
(0.00,0.55)\end{array}$ & $\begin{array}{c}-0.22 * * * \\
(0.00,0.67)\end{array}$ & $\begin{array}{c}0.00 \\
(0.90,0.00)\end{array}$ & $\begin{array}{c}-0.05^{* * *} \\
(0.00,0.62)\end{array}$ & $\begin{array}{c}-0.03 * * * \\
(0.00,0.43)\end{array}$ \\
\hline $\begin{array}{l}\text { PRIVHEL/PRIVEDU/ } \\
\text { n.a./n.a. 1/ }\end{array}$ & $\begin{array}{c}-0.01 \\
(0.51,0.01)\end{array}$ & $\begin{array}{c}0.00 \\
(0.91,0.00)\end{array}$ & $\begin{array}{c}-0.17 * * * \\
(0.01,0.11)\end{array}$ & $\begin{array}{c}-0.04 \\
(0.12,0.05)\end{array}$ & $\begin{array}{c}-0.03 \\
(0.13,0.04)\end{array}$ & $\begin{array}{c}-0.12 * * \\
(0.03,0.10)\end{array}$ & & & & & & \\
\hline
\end{tabular}

Source: Fund staff calculations.

Notes: $N=79$. All regressions include a constant that is not reported. Heterocesdosticity-robust $P$-values and $\mathrm{R}^{2} \mathrm{~s}$ in parentheses. $* * * / * * / *$ indicates significance at the 1 percent $/ 5$ percent/ 10 percent levels, respectively.

$1 /$ The first, second, third, and fourth alternatives apply to the regressions for health, education, social protection, and all three social sectors, respectively. 
Table A3. Local Governments-Multivariate Regressions of Scores

\begin{tabular}{|c|c|c|c|c|c|c|c|c|c|c|c|c|}
\hline \multirow[t]{2}{*}{ Dependent Variable } & \multicolumn{3}{|c|}{ Health } & \multicolumn{3}{|c|}{ Education } & \multicolumn{3}{|c|}{ Social Protection } & \multicolumn{3}{|c|}{ Social Sectors } \\
\hline & PSP & PSE & DEA & PSP & PSE & DEA & PSP & PSE & DEA & PSP & PSE & DEA \\
\hline$\overline{C O N S T A N T}$ & $\begin{array}{c}0.73 * * * \\
(0.00)\end{array}$ & $\begin{array}{c}0.01 \\
(0.95)\end{array}$ & $\begin{array}{l}-0.75 \\
(0.22)\end{array}$ & $\begin{array}{l}0.56^{* *} \\
(0.02)\end{array}$ & $\begin{array}{l}-0.04 \\
(0.69)\end{array}$ & $\begin{array}{l}-0.58 \\
(0.57)\end{array}$ & $\begin{array}{c}1.25 * * * \\
(0.00)\end{array}$ & $\begin{array}{c}1.03 * * * \\
(0.00)\end{array}$ & $\begin{array}{c}0.51 \\
(0.11)\end{array}$ & $\begin{array}{c}0.85 * * * \\
(0.00)\end{array}$ & $\begin{array}{c}1.02 * * * \\
(0.01)\end{array}$ & $\begin{array}{c}0.04 \\
(0.90)\end{array}$ \\
\hline INCPERCAP & $\begin{array}{c}0.00 \\
(0.23)\end{array}$ & $\begin{array}{c}2.1 \mathrm{E}-6^{* *} \\
(0.02)\end{array}$ & $\begin{array}{c}4.5 \mathrm{E}-6^{*} \\
(0.07)\end{array}$ & $\begin{array}{c}0.00 \\
(0.26)\end{array}$ & $\begin{array}{c}2.1 \mathrm{E}-6^{* * *} \\
(0.00)\end{array}$ & $\begin{array}{c}2.1 \mathrm{E}-6^{* * *} \\
(0.00)\end{array}$ & $\begin{array}{c}0.00 \\
(0.26)\end{array}$ & $\begin{array}{c}0.00 \\
(0.49)\end{array}$ & $\begin{array}{c}2.1 \mathrm{E}-6^{* *} \\
(0.01)\end{array}$ & $\begin{array}{c}0.00 \\
(0.60)\end{array}$ & $\begin{array}{c}4.1 \mathrm{E}-6^{* * *} \\
(0.00)\end{array}$ & $\begin{array}{c}4.1 \mathrm{E}-6^{* * *} \\
(0.00)\end{array}$ \\
\hline FUEL & $\begin{array}{c}0.00 \\
(0.81)\end{array}$ & $\begin{array}{c}0.00 \\
(0.49)\end{array}$ & $\begin{array}{c}0.00 \\
(0.48)\end{array}$ & $\begin{array}{c}0.00 \\
(0.36)\end{array}$ & $\begin{array}{c}0.00 \\
(0.12)\end{array}$ & $\begin{array}{c}0.00 \\
(0.51)\end{array}$ & $\begin{array}{c}0.00 \\
(0.37)\end{array}$ & $\begin{array}{c}2.3 \mathrm{E}-3^{* *} \\
(0.02)\end{array}$ & $\begin{array}{c}3.0 \mathrm{E}-3^{* *} \\
(0.02)\end{array}$ & $\begin{array}{c}0.00 \\
(0.33)\end{array}$ & $\begin{array}{c}0.00 \\
(0.12)\end{array}$ & $\begin{array}{c}0.00 \\
(0.50)\end{array}$ \\
\hline$A L C T O B$ & $\begin{array}{c}0.02 \\
(0.16)\end{array}$ & $\begin{array}{l}-0.01 \\
(0.66)\end{array}$ & $\begin{array}{l}-0.01 \\
(0.91)\end{array}$ & $\begin{array}{c}0.02 \\
(0.41)\end{array}$ & $\begin{array}{l}-0.01 \\
(0.33)\end{array}$ & $\begin{array}{c}0.09 \\
(0.28)\end{array}$ & $\begin{array}{l}-0.01 \\
(0.48)\end{array}$ & $\begin{array}{l}-0.03 \\
(0.16)\end{array}$ & $\begin{array}{c}0.00 \\
(0.84)\end{array}$ & $\begin{array}{c}0.01 \\
(0.48)\end{array}$ & $\begin{array}{l}-0.03 \\
(0.31)\end{array}$ & $\begin{array}{c}0.00 \\
(0.92)\end{array}$ \\
\hline$O L D$ & $\begin{array}{c}0.00 \\
(0.97)\end{array}$ & $\begin{array}{c}0.00 \\
(0.27)\end{array}$ & $\begin{array}{c}0.02 \\
(0.19)\end{array}$ & $\begin{array}{l}0.01^{*} \\
(0.08)\end{array}$ & $\begin{array}{c}0.01 * * * \\
(0.01)\end{array}$ & $\begin{array}{c}0.01 \\
(0.67)\end{array}$ & $\begin{array}{c}0.00 \\
(0.89)\end{array}$ & $\begin{array}{c}0.00 \\
(0.90)\end{array}$ & $\begin{array}{c}0.00 \\
(0.90)\end{array}$ & $\begin{array}{c}0.00 \\
(0.26)\end{array}$ & $\begin{array}{c}0.01 \\
(0.14)\end{array}$ & $\begin{array}{c}0.00 \\
(0.49)\end{array}$ \\
\hline DENSITY & $\begin{array}{c}0.00 \\
(0.72)\end{array}$ & $\begin{array}{c}0.00 \\
(0.69)\end{array}$ & $\begin{array}{c}-1.1 \mathrm{E}-3 * \\
(0.10)\end{array}$ & $\begin{array}{c}0.00 \\
(0.94)\end{array}$ & $\begin{array}{c}0.00 \\
(0.85)\end{array}$ & $\begin{array}{c}0.00 \\
(0.65)\end{array}$ & $\begin{array}{c}0.00 \\
(1.00)\end{array}$ & $\begin{array}{c}0.00 \\
(0.92)\end{array}$ & $\begin{array}{c}0.00 \\
(0.34)\end{array}$ & $\begin{array}{c}0.00 \\
(0.75)\end{array}$ & $\begin{array}{c}0.00 \\
(0.76)\end{array}$ & $\begin{array}{c}0.00 \\
(0.18)\end{array}$ \\
\hline TEMPJAN & $\begin{array}{c}0.00 \\
(0.84)\end{array}$ & $\begin{array}{c}0.00 \\
(0.41)\end{array}$ & $\begin{array}{c}0.01 \\
(0.29)\end{array}$ & $\begin{array}{c}0.00 \\
(0.52)\end{array}$ & $\begin{array}{c}0.00 \\
(0.97)\end{array}$ & $\begin{array}{l}0.01 * \\
(0.06)\end{array}$ & $\begin{array}{c}3.9 \mathrm{E}-3 * \\
(0.08)\end{array}$ & $\begin{array}{c}0.00 \\
(0.51)\end{array}$ & $\begin{array}{c}0.00 \\
(0.86)\end{array}$ & $\begin{array}{c}0.00 \\
(0.46)\end{array}$ & $\begin{array}{c}0.00 \\
(0.81)\end{array}$ & $\begin{array}{c}0.00 \\
(0.22)\end{array}$ \\
\hline MOSCOW & $\begin{array}{c}0.00 \\
(0.45)\end{array}$ & $\begin{array}{c}0.00 \\
(0.19)\end{array}$ & $\begin{array}{c}0.00 \\
(0.28)\end{array}$ & $\begin{array}{c}0.00 \\
(0.64)\end{array}$ & $\begin{array}{c}0.00 \\
(0.76)\end{array}$ & $\begin{array}{c}-4.0 \mathrm{E}-5^{* *} \\
(0.04)\end{array}$ & $\begin{array}{c}0.00 \\
(0.14)\end{array}$ & $\begin{array}{c}0.00 \\
(0.35)\end{array}$ & $\begin{array}{c}-1.9 \mathrm{E}-5^{* *} \\
(0.01)\end{array}$ & $\begin{array}{c}-1.0 \mathrm{E}-5^{*} \\
(0.09)\end{array}$ & $\begin{array}{c}0.00 \\
(0.48)\end{array}$ & $\begin{array}{c}-1.9 \mathrm{E}-5 * * \\
(0.02)\end{array}$ \\
\hline POPULATION & $\begin{array}{c}0.00 \\
(0.74)\end{array}$ & $\begin{array}{c}0.00 \\
(0.43)\end{array}$ & $\begin{array}{c}0.00 \\
(0.28)\end{array}$ & $\begin{array}{c}-3.5 \mathrm{E}-5^{* *} \\
(0.03)\end{array}$ & $\begin{array}{c}0.00 \\
(0.30)\end{array}$ & $\begin{array}{c}0.00 \\
(0.37)\end{array}$ & $\begin{array}{c}-3.5 \mathrm{E}-5^{*} \\
(0.08)\end{array}$ & $\begin{array}{c}0.00 \\
(0.85)\end{array}$ & $\begin{array}{c}0.00 \\
(0.21)\end{array}$ & $\begin{array}{c}0.00 \\
(0.72)\end{array}$ & $\begin{array}{c}0.00 \\
(0.45)\end{array}$ & $\begin{array}{c}-3.5 \mathrm{E}-5 * * \\
(0.02)\end{array}$ \\
\hline TRANSFERS & $\begin{array}{c}0.00 \\
(0.59)\end{array}$ & $\begin{array}{c}-2.2 \mathrm{E}-3 * * \\
(0.03)\end{array}$ & $\begin{array}{c}0.00 \\
(0.50)\end{array}$ & $\begin{array}{c}0.00 \\
(0.96)\end{array}$ & $\begin{array}{c}0.00 \\
(0.12)\end{array}$ & $\begin{array}{c}0.00 \\
(0.42)\end{array}$ & $\begin{array}{c}3.1 \mathrm{E}-3^{* *} \\
(0.01)\end{array}$ & $\begin{array}{c}0.00 \\
(0.75)\end{array}$ & $\begin{array}{c}0.00 \\
(0.84)\end{array}$ & $\begin{array}{c}0.00 \\
(0.19)\end{array}$ & $\begin{array}{c}-4.9 \mathrm{E}-3 * * \\
(0.04)\end{array}$ & $\begin{array}{c}0.00 \\
(0.32)\end{array}$ \\
\hline RISK & $\begin{array}{c}0.02 * * \\
(0.04)\end{array}$ & $\begin{array}{c}0.01 \\
(0.30)\end{array}$ & $\begin{array}{l}0.07 * * \\
(0.02)\end{array}$ & $\begin{array}{c}0.00 \\
(0.90)\end{array}$ & $\begin{array}{c}0.00 \\
(0.89)\end{array}$ & $\begin{array}{c}0.01 \\
(0.77)\end{array}$ & $\begin{array}{c}0.01 \\
(0.59)\end{array}$ & $\begin{array}{l}-0.01 \\
(0.45)\end{array}$ & $\begin{array}{c}-0.03 * * \\
(0.07)\end{array}$ & $\begin{array}{c}0.01 \\
(0.12)\end{array}$ & $\begin{array}{l}-0.01 \\
(0.81)\end{array}$ & $\begin{array}{c}0.01 \\
(0.69)\end{array}$ \\
\hline SHADOW & $\begin{array}{c}0.00 \\
(0.12)\end{array}$ & $\begin{array}{c}0.00 \\
(0.31)\end{array}$ & $\begin{array}{c}0.01 \\
(0.15)\end{array}$ & $\begin{array}{c}0.00 \\
(0.84)\end{array}$ & $\begin{array}{c}0.00 \\
(0.45)\end{array}$ & $\begin{array}{c}0.00 \\
(0.56)\end{array}$ & $\begin{array}{c}-0.01 * * * \\
(0.00)\end{array}$ & $\begin{array}{c}0.00 \\
(0.20)\end{array}$ & $\begin{array}{c}0.00 \\
(0.91)\end{array}$ & $\begin{array}{c}-2.8 \mathrm{E}-3 * * \\
(0.01)\end{array}$ & $\begin{array}{c}0.00 \\
(0.95)\end{array}$ & $\begin{array}{c}0.00 \\
(0.41)\end{array}$ \\
\hline ACADEMIC & $\begin{array}{c}4.8 \mathrm{E}-3 * * \\
(0.04)\end{array}$ & $\begin{array}{c}0.01 * * * \\
(0.00)\end{array}$ & $\begin{array}{c}0.03^{* * *} \\
(0.00)\end{array}$ & $\begin{array}{c}0.00 \\
(0.89)\end{array}$ & $\begin{array}{c}0.00 \\
(0.13)\end{array}$ & $\begin{array}{c}0.01 \\
(0.44)\end{array}$ & $\begin{array}{c}0.00 \\
(0.43)\end{array}$ & $\begin{array}{c}0.00 \\
(0.71)\end{array}$ & $\begin{array}{c}0.00 \\
(0.74)\end{array}$ & $\begin{array}{c}2.6 \mathrm{E}-3 * \\
(0.09)\end{array}$ & $\begin{array}{c}0.01 \\
(0.18)\end{array}$ & $\begin{array}{l}0.01 * * \\
(0.05)\end{array}$ \\
\hline$U R B A N$ & $\begin{array}{c}0.00 \\
(0.11)\end{array}$ & $\begin{array}{c}0.00 \\
(0.26)\end{array}$ & $\begin{array}{l}0.01 * * \\
(0.05)\end{array}$ & $\begin{array}{c}3.6 \mathrm{E}-3^{* *} * \\
(0.02)\end{array}$ & $\begin{array}{c}3.6 \mathrm{E}-3 * \\
(0.09)\end{array}$ & $\begin{array}{c}0.00 \\
(0.42)\end{array}$ & $\begin{array}{c}-3.5 \mathrm{E}-3 * * \\
(0.01)\end{array}$ & $\begin{array}{c}0.00 \\
(0.18)\end{array}$ & $\begin{array}{c}3.6 \mathrm{E}-3^{* *} \\
(0.04)\end{array}$ & $\begin{array}{c}0.00 \\
(0.57)\end{array}$ & $\begin{array}{c}0.00 \\
(0.99)\end{array}$ & $\begin{array}{c}4.5 \mathrm{E}-3 * * * \\
(0.00)\end{array}$ \\
\hline $\begin{array}{l}\text { EXPHEL/EXPEDU/ } \\
\text { EXPSOC/EXPTOT } 1 /\end{array}$ & $\begin{array}{l}-0.01 \\
(0.19)\end{array}$ & $\begin{array}{c}-0.03 * * * \\
(0.00)\end{array}$ & $\begin{array}{c}0.01 \\
(0.68)\end{array}$ & $\begin{array}{c}0.00 \\
(0.94)\end{array}$ & $\begin{array}{l}-0.01 \\
(0.17)\end{array}$ & $\begin{array}{l}-0.06 \\
(0.24)\end{array}$ & $\begin{array}{c}0.02 \\
(0.23)\end{array}$ & $\begin{array}{c}-0.11 * * * \\
(0.00)\end{array}$ & $\begin{array}{c}-0.10^{* * *} \\
(0.00)\end{array}$ & $\begin{array}{c}0.00 \\
(0.75)\end{array}$ & $\begin{array}{c}-0.02 * * * \\
(0.00)\end{array}$ & $\begin{array}{c}0.00 \\
(0.38)\end{array}$ \\
\hline $\begin{array}{l}\text { PRIVHEL/PRIVEDU/ } \\
\text { n.a./n.a. } 1 /\end{array}$ & $\begin{array}{c}0.01 \\
(0.62)\end{array}$ & $\begin{array}{c}0.00 \\
(0.77)\end{array}$ & $\begin{array}{c}-0.12 * * \\
(0.02)\end{array}$ & $\begin{array}{l}-0.01 \\
(0.57)\end{array}$ & $\begin{array}{c}0.01 \\
(0.36)\end{array}$ & $\begin{array}{l}-0.05 \\
(0.40)\end{array}$ & & & & & & \\
\hline Adjusted $R^{2}$ & 0.33 & 0.76 & 0.35 & 0.26 & 0.80 & 0.54 & 0.60 & 0.65 & 0.70 & 0.16 & 0.79 & 0.66 \\
\hline
\end{tabular}

Source: Fund staff calculations.

Notes: $N=79$. Heteroscedosticity-robust $P$-values in parentheses. $* * * / * * / *$ indicates significance at the 1 percent $/ 5$ percent $/ 10$ percent level, respectively.

$1 /$ The first, second, third, and fourth alternatives apply to the regressions for health, education, social protection, and all three social sectors, respectively. 
Table A4. Local Governments-Tested-Down Regressions of Scores

\begin{tabular}{|c|c|c|c|c|c|c|c|c|c|c|c|c|}
\hline \multirow[t]{2}{*}{ Dependent Variable } & \multicolumn{3}{|c|}{ Health } & \multicolumn{3}{|c|}{ Education } & \multicolumn{3}{|c|}{ Social Protection } & \multicolumn{3}{|c|}{ Social Sectors } \\
\hline & PSP & PSE & DEA & PSP & PSE & DEA & PSP & PSE & DEA & PSP & PSE & DEA \\
\hline CONSTANT & $\begin{array}{l}0.86^{* * * *} \\
(0.00)\end{array}$ & & & $\begin{array}{c}0.61 * * * \\
(0.00)\end{array}$ & & $\begin{array}{l}0.54 * * \\
(0.03)\end{array}$ & $\begin{array}{l}1.26^{* * * *} \\
(0.00)\end{array}$ & $\begin{array}{c}0.93 * * * \\
(0.00)\end{array}$ & $\begin{array}{l}0.64 * * * \\
(0.0007)\end{array}$ & $\begin{array}{c}1.04 * * * \\
(0.00)\end{array}$ & $\begin{array}{c}0.70^{* * *} \\
(0.00)\end{array}$ & \\
\hline INCPERCAP & & $\begin{array}{l}2.1 \mathrm{E}-6^{* * *} \\
(0.00)\end{array}$ & $\begin{array}{c}2.1 \mathrm{E}-6^{*} \\
(0.09)\end{array}$ & $\begin{array}{l}9.1 \mathrm{E}-7 * * * \\
\quad(0.00)\end{array}$ & $\begin{array}{l}2.1 \mathrm{E}-6^{* * *} \\
\quad(0.00)\end{array}$ & $\begin{array}{l}1.1 \mathrm{E}-5^{* * *} \\
(0.00)\end{array}$ & & & & & $\begin{array}{l}2.1 \mathrm{E}-6^{* * *} \\
(0.00)\end{array}$ & $\begin{array}{l}4.8 \mathrm{E}-6^{* * *} \\
\quad(0.00)\end{array}$ \\
\hline FUEL & & & & & $\begin{array}{c}7.5 \mathrm{E}-4^{* *} \\
(0.03)\end{array}$ & & & $\begin{array}{l}2.8 \mathrm{E}-3 * * * \\
(0.00)\end{array}$ & $\begin{array}{l}3.9 \mathrm{E}-3 * * * \\
(0.01)\end{array}$ & & $\begin{array}{l}3.7 \mathrm{E}-3 * * * \\
(0.01)\end{array}$ & \\
\hline$A L C T O B$ & & & & & & & & $\begin{array}{l}-0.03 * \\
(0.01)\end{array}$ & & & & \\
\hline$O L D$ & & $\begin{array}{c}0.01 * * * \\
(0.00)\end{array}$ & $\begin{array}{c}0.01 * * * \\
(0.01)\end{array}$ & $\begin{array}{c}0.01 * * * \\
(0.00)\end{array}$ & $\begin{array}{c}0.01 * * * \\
(0.00)\end{array}$ & & & & & & $\begin{array}{c}0.02 * * * \\
(0.00)\end{array}$ & \\
\hline DENSITY & & & & & & & & & & & & \\
\hline TEMPJAN & & & & & & & $\begin{array}{l}7.0 \mathrm{E}-3 * * * \\
(0.00)\end{array}$ & & & & & \\
\hline MOSCOW & & & & & & $\begin{array}{c}-5.1 \mathrm{E}-5^{* * *} \\
(0.01)\end{array}$ & & $\begin{array}{c}-1.0 \mathrm{E}-5^{* * *} \\
(0.01)\end{array}$ & $\begin{array}{c}-1.6 \mathrm{E}-5^{* * *} \\
(0.00)\end{array}$ & $\begin{array}{c}-1.0 \mathrm{E}-5^{* * *} \\
(0.00)\end{array}$ & & $\begin{array}{l}-3.1 \mathrm{E}-5^{* * *} \\
(0.00)\end{array}$ \\
\hline POPULATION & & & & $\begin{array}{c}-3.1 \mathrm{E}-5^{* * *} \\
(0.00)\end{array}$ & $\begin{array}{l}1.0 \mathrm{E}-5 * * * \\
(0.00)\end{array}$ & & $\begin{array}{c}2.0 \mathrm{E}-5^{* *} \\
(0.02)\end{array}$ & & & & & $\begin{array}{c}-2.6 \mathrm{E}-5^{*} \\
(0.06)\end{array}$ \\
\hline TRANSFERS & & $\begin{array}{c}-2.8 \mathrm{E}-3 * * * \\
(0.00)\end{array}$ & $\begin{array}{c}-4.2 \mathrm{E}-3 * \\
(0.08)\end{array}$ & & & & $\begin{array}{c}2.6 \mathrm{E}-3 * * * \\
(0.00)\end{array}$ & & & $\begin{array}{c}-5.5 \mathrm{E}-3 * \\
(0.00)\end{array}$ & & \\
\hline RISK & $\begin{array}{l}0.02 * * \\
(0.03)\end{array}$ & & $\begin{array}{l}0.06^{*} \\
(0.07)\end{array}$ & & & & & & & $\begin{array}{c}0.02 * * * \\
(0.01)\end{array}$ & & \\
\hline SHADOW & $\begin{array}{c}-4.2 \mathrm{E}-3 * * * \\
(0.00)\end{array}$ & $\begin{array}{l}2.9 \mathrm{E}-3 * * * \\
(0.01)\end{array}$ & & & & & $\begin{array}{l}-4.9 \mathrm{E}-3 * * * \\
(0.00)\end{array}$ & $\begin{array}{c}-2.3 \mathrm{E}-3 * \\
(0.10)\end{array}$ & & $\begin{array}{c}-2.5 \mathrm{E}-3 * * * \\
(0.00)\end{array}$ & & \\
\hline ACADEMIC & $\begin{array}{c}4.6 \mathrm{E}-3 * * \\
(0.02)\end{array}$ & $\begin{array}{c}0.01 * * * \\
(0.00)\end{array}$ & $\begin{array}{c}0.02 * * * \\
(0.00)\end{array}$ & & $\begin{array}{c}2.0 \mathrm{E}-3 * * \\
(0.03)\end{array}$ & & & & & & $\begin{array}{l}0.01^{* *} \\
(0.02)\end{array}$ & \\
\hline$U R B A N$ & $\begin{array}{c}2.0 \mathrm{E}-3 * * \\
(0.02)\end{array}$ & & & $\begin{array}{l}3.1 \mathrm{E}-3 * * * \\
(0.00)\end{array}$ & & & $\begin{array}{c}-3.8 \mathrm{E}-3 * * * \\
(0.00)\end{array}$ & & $\begin{array}{c}3.9 \mathrm{E}-3 * \\
(0.06)\end{array}$ & & & $\begin{array}{l}6.6 \mathrm{E}-3 * * * \\
(0.00)\end{array}$ \\
\hline $\begin{array}{l}\text { EXPHEL/EXPEDU/ } \\
\text { EXPSOC/EXPTOT 1/ }\end{array}$ & $\begin{array}{c}-0.02 * * * \\
(0.00)\end{array}$ & $\begin{array}{c}-0.02 * * * \\
(0.00)\end{array}$ & & & $\begin{array}{c}-0.01 * * * \\
(0.00)\end{array}$ & $\begin{array}{c}-0.06^{* *} \\
(0.03)\end{array}$ & $\begin{array}{c}0.04 * * * \\
(0.01)\end{array}$ & $\begin{array}{c}-0.11 * * * \\
(0.00)\end{array}$ & $\begin{array}{c}-0.15^{* * *} \\
(0.00)\end{array}$ & & $\begin{array}{c}-0.02 * * * \\
(0.00)\end{array}$ & \\
\hline $\begin{array}{l}\text { PRIVHEL/PRIVEDU/ } \\
\text { n.a./n.a. 1/ }\end{array}$ & & & $\begin{array}{c}-0.13 * * * \\
(0.01)\end{array}$ & & & & & & & & & \\
\hline Adjusted $R^{2}$ & 0.36 & 0.77 & 0.36 & 0.34 & 0.80 & 0.55 & 0.61 & 0.68 & 0.71 & 0.19 & 0.80 & 0.67 \\
\hline Endogeneity test $p 2 /$ & 0.38 & 0.35 & 0.40 & n.a. & $0.49,0.31$ & 0.58 & 0.23 & 0.61 & 0.15 & n.a. & 0.66 & n.a. \\
\hline
\end{tabular}

Notes: $N=79$. Heteroscedosticity-robust $P$-values in parentheses. $* * * * * / *$ indicates significance at the 1 percent $/ 5$ percent/10 percent level, respectively.

$1 /$ The first, second, third, and fourth alternatives apply to the regressions for health, education, social protection, and all three social sectors, respectively.

2/ P-value(s) of coefficients on residuals from auxiliary regressions added to the regressors; when more than one of the potentially endogenous variables is included in a given regression, the $p$-values are given in the order of appearance of the variables above. See Appendix I for more details. 


\section{References}

Afonso, A., and M. St. Aubyn, 2006, "Cross-country Efficiency of Secondary Education Provision: A Semi-Parametric Analysis with Non-Discretionary Inputs," Economic Modelling, Vol. 23, May pp.476-91.—, L. Schuknecht, and V. Tanzi, 2005, "Public Sector Efficiency: An International Comparison," Public Choice, Vol. 123 nos.3-4, pp. 321-47.

— 2006, "Public Sector Efficiency: Evidence for the New EU Member States and Emerging Markets," ECB Working Paper No. 581 (Frankfurt: European Central Bank).

Aninat, E., A. Bauer, and K. Cowan, 1999, “Addressing Equity in Policymaking: Lessons from the Chilean Experience," Economic Policy and Equity, ed. By V. Tanzi, K. $\mathrm{Chu}$, and S. Gupta (Washington: International Monetary Fund).

Baumol, W.J., 1967, "Macroeconomics of Unbalanced Growth: The Anatomy of the Urban Crisis," American Economic Review, Vol. 57, (June) pp. 415-26.

Berkowitz, D., and D.N. DeJong, 2003, "Policy Reform and Growth in Post-Soviet Russia," European Economic Review Vol. 47, April, pp. 337-52.

Bulir, A., and A. Hamann, 2000, “Aid Volatility: An Empirical Assessment," Staff Papers, IMF, Vol. 50 No. 1, pp. 64-89.

Dabla-Norris, E., and S. Weber, 2001, "Regional Disparities and Transfer Policies in Russia: Theory and Evidence," IMF Working Paper 01/199 (Washington: International Monetary Fund).

- M. Gradstein, and G. Inchauste, 2005, "What Causes Firms to Hide Output? The Determinants of Informality," IMF Working Paper 05/160 (Washington: International Monetary Fund).

DaVanzo, J., and C. Grammich, 2001, Russia's Mortality Crisis: Drinking, Disease, and Deteriorating Health Care (Santa Monica: Rand Corporation).

Debreu, G., 1951, “The Coefficient of Resource Utilization,” Econometrica Vol. 19, July pp. 273-92.

Desai, R.M., L. Freinkman, and I. Goldberg, 2005, "Fiscal Federalism in Rentier Regions: Evidence from Russia," Journal of Comparative Economics Vol 33, 641-54 December, pp. 814-34.

Färe, R., S. Grosskopf, and C.A.K. Lovell, 1994, Production Frontiers (Cambridge: Cambridge University Press).

Farrell, M. J., 1957, “The Measurement of Productive Efficiency,” Journal of Royal 
Statistical Society, Vol. 120 Series A, pp. 253-81.

Gellner, E., 1994, Conditions of Liberty: Civil Society and Its Rivals (Harmondsworth, England: Allen Lane/Penguin Press).

Gimpelson, Vladimir, and Daniel Treisman, 2002, "Fiscal Games and Public Employment: A Theory With Evidence From Russia," World Politics Vol. 54, January, pp.145-83.

Gupta, S., and M. Verhoeven, 2001, "The Efficiency of Government Expenditure: Experiences from Africa," Journal of Policy Modeling Vol. May, pp. 23, 433-67.

Hauner, D., 2005, "Explaining Efficiency Differences Among Large German and Austrian Banks," Applied Economic, Vol. 37, May, pp. 969-80.

Herrera, S., and G. Pang, 2005, "Efficiency of Public Spending in Developing Countries: An Efficiency Frontier Approach," World Bank Policy Research Working Paper 3645 (Washington: World Bank).

IMF, 2006, "Managing Russia's Oil Wealth: An Assessment of Sustainable Expenditure Paths," in Russian Federation-Staff Report for the 2006 Article IV Consultation, IMF Country Report No. 061 (Washington: International Monetary Fund).

Koopmans, T. C., 1951, "An Analysis of Production as an Efficient Combination of Activities," in Activity Analysis of Production and Allocation, ed. By T. C. Koopmans (New York: Wiley).

Kwon, G., and A. Spilimbergo, 2005, "Russia's Regions: Income Volatility, Labor Mobility, and Fiscal Policy,"IMF Working Paper 05/185 (Washington: International Monetary Fund).

La Porta, R., and others, 1997, "Trust in Large Organizations," American Economic Review Vol. 87 May, pp. 333-8.

Marquez, P., 2005, Dying Too Young. Addressing Premature Mortality and Ill Health Due to Non-Communicable Diseases and Injuries in the Russian Federation (Washington: World Bank).

Mattina, T., and V. Gunnarsson, 2006, "Budget Rigidity and Expenditure Efficiency in Slovenia," in Slovenia-Selected Issues, IMF Country Report No. 06/250, by J. Fernandez-Ansola and others (Washington: International Monetary Fund).

OECD, 2006, "Reforming Healthcare," in Economic Surveys: The Russian Federation (Paris: Organization for Economic Cooperation and Development).

Popov, V., 2004, "Fiscal Federalism in Russia: Rules versus Electoral Politics," Comparative Economic Studies Vol. 46, December, pp. 515-41. 
Putnam, R. D., 1993, Making Democracy Work. Civic Traditions in Modern Italy (Princeton New Jersey: Princeton University Press).

Rosstat, 2006, Regions of Russia: Moscow: Rosstat.

Simar, L., and P.W. Wilson, 2007, "Estimation and Inference in Two-Stage, Semi-Parametric Models of Production Processes," Journal of Econometrics Vol. 136, No.1 pp. 31-64.

Tanzi, V., and L. Schuknecht, 1997, "Reconsidering the Role of Government: The International Perspective," American Economic Review, Vol. 87, May, pp. 164-8.

- 2000, Public Spending in the 20 ${ }^{\text {th }}$ Century: A Global Perspective (Cambridge: Cambridge University Press).

Ter-Minassian, T., ed., 1997, Fiscal Federalism in Theory and Practice (Washington: International Monetary Fund).

Treisman, D., 1996, "The Politics of Intergovernmental Transfers in Post-Soviet Russia," British Journal of Political Science Vol. 26, July, pp. 299-335.

World Bank, 2004, Russian Federation-Poverty Assessment, Report No. 28923-RU Washington: World Bank.

— 2005, Russia-Fiscal Costs of Structural Reforms, Report No. 30741-RU Washington: World Bank

__, 2007, "Education: Focus on Access and Quality” unpublished; Washington: World Bank

Worthington, A.C., and B.E. Dollery, 2002, "Incorporating Contextual Information in Public Sector Efficiency Analyses: A Comparative Study of NSW Local Government," Applied Economics Vol. 34), No. 4 pp. 453-64.

Zhuravskaya, E.V., 2000, “Incentives to Provide Local Public Goods: Fiscal Federalism, Russian Style,” Journal of Public Economics Vol. 76 No.3, pp.337-68. 